\title{
Past changes in the vertical distribution of ozone - Part 1: Measurement techniques, uncertainties and availability
}

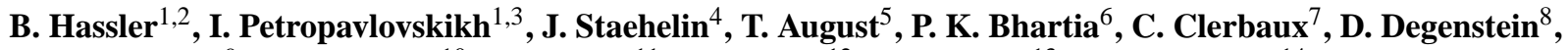 \\ M. De Mazière ${ }^{9}$, B. M. Dinelli ${ }^{10}$, A. Dudhia ${ }^{11}$, G. Dufour ${ }^{12}$, S. M. Frith ${ }^{13}$, L. Froidevaux ${ }^{14}$, S. Godin-Beekmann $^{15}$, \\ J. Granville ${ }^{9}$, N. R. P. Harris ${ }^{16}$, K. Hoppel ${ }^{17}$, D. Hubert ${ }^{9}$, Y. Kasai ${ }^{18}$, M. J. Kurylo ${ }^{19}$, E. Kyrölä ${ }^{20}$, J.-C. Lambert $^{9}$, \\ P. F. Levelt ${ }^{21}$, C. T. McElroy ${ }^{22}$, R. D. McPeters ${ }^{6}$, R. Munro ${ }^{5}$, H. Nakajima ${ }^{23}$, A. Parrish ${ }^{24}$, P. Raspollini $^{25}$, \\ E. E. Remsberg ${ }^{26}$, K. H. Rosenlof ${ }^{2}$, A. Rozanov $^{27}$, T. Sano ${ }^{28}$, Y. Sasano ${ }^{29}$, M. Shiotani ${ }^{28}$, H. G. J. Smit ${ }^{30}$, G. Stiller ${ }^{31}$, \\ J. Tamminen ${ }^{20}$, D. W. Tarasick ${ }^{32}$, J. Urban ${ }^{33}$, R. J. van der A ${ }^{21}$, J. P. Veefkind ${ }^{21}$, C. Vigouroux ${ }^{9}$, T. von Clarmann ${ }^{31}$, \\ C. von Savigny ${ }^{34}$, K. A. Walker ${ }^{35,36}$, M. Weber ${ }^{27}$, J. Wild ${ }^{37}$, and J. M. Zawodny ${ }^{26}$
}

${ }^{1}$ CIRES, University of Colorado at Boulder, Boulder, Colorado, USA

${ }^{2}$ NOAA/ESRL, Chemical Sciences Division, Boulder, Colorado, USA

${ }^{3}$ NOAA/ESRL, Global Monitoring Division, Boulder, Colorado, USA

${ }^{4}$ ETH-Zürich, Zürich, Switzerland

${ }^{5}$ EUMETSAT, Darmstadt, Germany

${ }^{6}$ NASA Goddard Space Flight Center, Greenbelt, Maryland, USA

${ }^{7}$ UPMC Univ. Paris 06, Université Versailles St-Quentin, CNRS/INSU, LATMOS-IPSL, Paris, France

${ }^{8}$ University of Saskatchewan, Saskatoon, Saskatchewan, Canada

${ }^{9}$ Belgian Institute for Space Aeronomy (IASB-BIRA), Brussels, Belgium

${ }^{10}$ ISAC-CNR, Bologna, Italy

${ }^{11}$ AOPP, Physics Department, University of Oxford, Oxford, UK

${ }^{12}$ LISA, UMR CNRS 7583, Université Paris-Est Créteil et Université Paris-Diderot, 27 Créteil, France

${ }^{13}$ Science Systems and Applications, Inc., NASA GSFC, Greenbelt, Maryland, USA

${ }^{14}$ Jet Propulsion Laboratory, California Institute of Technology, Pasadena, California, USA

${ }^{15}$ Observatoire de Versailles Saint-Quentin-en-Yvelines, Guyancourt Cedex, France

${ }^{16}$ University of Cambridge, Chemistry Department, Cambridge, UK

${ }^{17}$ Remote Sensing Division, Naval Research Laboratory, Washington, D.C., USA

${ }^{18}$ National Institute of Information and Communications Technology, Tokyo, Japan

${ }^{19}$ Universities Space Research Association, Goddard Earth Sciences, Technology, and Research, NASA Goddard Space

Flight Center, Greenbelt, Maryland, USA

${ }^{20}$ Finnish Meteorological Institute, Earth Observation, Helsinki, Finland

${ }^{21}$ Royal Netherlands Meteorological Institute (KNMI), De Bilt, the Netherlands

${ }^{22}$ Department of Earth and Space Science and Engineering (Lassonde School of Engineering), York University,

Toronto, Canada

${ }^{23}$ National Institute for Environmental Studies, Tsukuba, Japan

${ }^{24}$ Department of Astronomy, University of Massachusetts, Amherst, Massachusetts, USA

${ }^{25}$ Istituto di Fisica Applicata "N. Carrara" (IFAC) del Consiglio Nazionale delle Ricerche (CNR), Florence, Italy

${ }^{26}$ NASA Langley Research Center, Hampton, Virginia, USA

${ }^{27}$ Institute of Environmental Physics Remote Sensing (IUP/IFE), University of Bremen, Bremen, Germany

${ }^{28}$ Research Institute for Sustainable Humanosphere, Kyoto University, Kyoto, Japan

${ }^{29}$ Association of International Research Initiatives for Environmental Studies, Tokyo, Japan

${ }^{30}$ Research Centre Jülich, Institute for Energy and Climate Research: Troposphere (IEK-8), Jülich, Germany

${ }^{31}$ Karlsruhe Institute of Technology, Institute for Meteorology and Climate Research, Karlsruhe, Germany

${ }^{32}$ Environment Canada, Downsview, Ontario, Canada

${ }^{33}$ Chalmers University of Technology, Department of Earth and Space Sciences, Göteborg, Sweden 
${ }^{34}$ Institut für Physik, Ernst-Moritz-Arndt-Universität Greifswald, Greifswald, Germany

${ }^{35}$ Department of Physics, University of Toronto, Toronto, Ontario, Canada

${ }^{36}$ Department of Chemistry, University of Waterloo, Waterloo, Ontario, Canada

${ }^{37}$ Innovim, LLC, NOAA/NWS/NCEP/Climate Prediction Center, College Park, Maryland, USA

Correspondence to: B. Hassler (birgit.hassler@noaa.gov)

Received: 21 October 2013 - Published in Atmos. Meas. Tech. Discuss.: 14 November 2013

Revised: 26 March 2014 - Accepted: 27 March 2014 - Published: 21 May 2014

\begin{abstract}
Peak stratospheric chlorofluorocarbon (CFC) and other ozone depleting substance (ODS) concentrations were reached in the mid- to late 1990s. Detection and attribution of the expected recovery of the stratospheric ozone layer in an atmosphere with reduced ODSs as well as efforts to understand the evolution of stratospheric ozone in the presence of increasing greenhouse gases are key current research topics. These require a critical examination of the ozone changes with an accurate knowledge of the spatial (geographical and vertical) and temporal ozone response. For such an examination, it is vital that the quality of the measurements used be as high as possible and measurement uncertainties well quantified.
\end{abstract}

In preparation for the 2014 United Nations Environment Programme (UNEP)/World Meteorological Organization (WMO) Scientific Assessment of Ozone Depletion, the SPARC/IO ${ }_{3} \mathrm{C} / \mathrm{IGACO}-\mathrm{O}_{3} / \mathrm{NDACC}\left(\mathrm{SI}^{2} \mathrm{~N}\right)$ Initiative was designed to study and document changes in the global ozone profile distribution. This requires assessing long-term ozone profile data sets in regards to measurement stability and uncertainty characteristics. The ultimate goal is to establish suitability for estimating long-term ozone trends to contribute to ozone recovery studies. Some of the data sets have been improved as part of this initiative with updated versions now available.

This summary presents an overview of stratospheric ozone profile measurement data sets (ground and satellite based) available for ozone recovery studies. Here we document measurement techniques, spatial and temporal coverage, vertical resolution, native units and measurement uncertainties. In addition, the latest data versions are briefly described (including data version updates as well as detailing multiple retrievals when available for a given satellite instrument). Archive location information for each data set is also given.

\section{Introduction}

As man-made ozone depleting substances (ODSs) decline in the stratosphere in response to the 1987 Montreal Protocol and its subsequent amendments and adjustments, the ozone layer is expected to recover globally. A small increase in stratospheric ozone abundance over northern mid-latitudes was first reported in the 2010 WMO ozone assessment
(WMO, 2011). Although supported by a variety of groundbased, balloon-born and satellite observations, statistical analysis could not attribute this change exclusively to the decline of ODSs due to observational uncertainty, geophysical and dynamical variability and changes in ozone due to increasing greenhouse gases that cool the stratosphere. Global total ozone remained significantly lower than during the early 1980 s, and surface ultraviolet radiation measurements were too variable to strongly support ozone recovery. Indications of the onset of stratospheric ozone recovery have been noted since the publication of the last ozone assessment. There are several recent publications (e.g. Maeder et al., 2010; Nair et al., 2013; Kuttippurath et al., 2013) supporting the statement that the second stage of ozone recovery is ongoing (as defined by the WMO, 2007, statement that "occurrence of statistically significant increases in ozone above previous minimum values due to declining equivalent effective stratospheric chlorine"). Other publications show that ozone recovery in Antarctica should be detectable within the next decade (Newman et al., 2006; Hassler et al., 2011). The additional four years of data available since analysis was done for the 2010 WMO ozone assessment as well as improvements in the homogenization of ozone data records should improve the signal-to-noise ratio in the ozone time series making trend analyses results more robust.

"SPARC Report No.1 - Trends in the vertical distribution of ozone" (SPARC, 1998) provided a comprehensive summary of available data and methods for trend analysis at that time. Its main objectives were to understand the limitations of the data, to assess the consistency between various data records and create a reference database for the analysis of long-term ozone changes as a function of altitude. One of the main reasons for this approach was to avoid misinterpreting instrument drifts as actual ozone changes.

Trend analysis is made more complex by the addition of new satellite records (e.g. Aura, Envisat, Odin, and SCISAT), where each covers a shorter time period than the traditionally used long-term records (e.g. ozonesondes, Umkehr, lidars, SAGE, HALOE). Adding to the problem, some of the long-term platforms have ceased taking measurements (e.g. SAGE, HALOE, instruments on Envisat), while records from other satellite platforms are difficult to combine due to drifting orbits (SBUV/2 on NOAA satellites) and different 
instrument generations (e.g. moving from SBUV fixed wavelength retrievals to Aura OMI hyper-spectral retrievals). For a full long-term analysis of stratospheric ozone throughout the decline due to increases in ODSs and subsequent recovery, multiple instrument records need to be considered. Thus, several different data sources have to be merged to allow a complete view of past ozone changes. Recent work has shown that ozone depletion and greenhouse gas (GHG) increases impact dynamical quantities in an additive manner, with ozone recovery possibly cancelling atmospheric circulation effects associated with increasing GHGs. (e.g. IPCC/TEAP, 2005; McLandress et al., 2010; Polvani et al., 2011). Clearly, an understanding of atmospheric transport, circulation and wave breaking patterns is important for our understanding of ozone recovery.

The consideration of uncertainties and artifacts is crucial in ozone trend analyses, particularly when the ozone recovery signal is small as compared to natural geophysical variability. As methods for trend and attribution analysis become more advanced, the uncertainties and instrumental artifacts buried in currently available data sets start to play a bigger role. Therefore, detailed information about measurement uncertainties, data jumps due to changes in instrumentation and drifts during long-term operation of a given instrument are essential.

There have been several attempts to produce historical global ozone profile data sets; these include satelliteozonesonde combinations starting in 1979 when the first global satellite measurements became available (e.g. Randel and $\mathrm{Wu}, 2007$; Bodeker et al., 2013), global ozone data sets that extend values to 2100 using model and fitting techniques (Hassler et al., 2009; Cionni et al., 2011) for use in global climate models without stratospheric ozone chemistry and also data sets that extend the historical record backward to 1900 (Brönnimann et al., 2013). Issues of biases between instruments, sampling, noise, gaps and differences in vertical registration (pressure or altitude) have to be addressed when creating combined data records to ensure no artificial trends are introduced.

Uncertainties in calculated ozone trends need to be reduced. In the 2010 WMO ozone assessment, inconsistencies in the available ozone profile data prevented a clear overall picture of long-term ozone profile changes. A successful assessment of trends for the upcoming 2014 WMO ozone assessment requires addressing the problems of time series artifacts due to changes in instrumentation, homogenizing applied satellite retrievals and reducing and describing measurement uncertainties. The SPARC/ $\mathrm{IO}_{3} \mathrm{C} / \mathrm{IGACO}-$ $\mathrm{O}_{3} / \mathrm{NDACC}\left(\mathrm{SI}^{2} \mathrm{~N}\right)$ Initiative has brought together scientists dealing with ground and satellite ozone profile measurements in order to consolidate efforts documenting long-term ozone profile changes. $\mathrm{SI}^{2} \mathrm{~N}$ has also defined the time frame to ensure that any data set improvements are finalized to ensure inclusion in the 2014 WMO ozone assessment analysis.
This paper provides a summary of the most important available ozone data sets, describes measurement methods, detection limits and uncertainty estimates, gives details about the vertical and temporal resolution of individual data sets and provides references to relevant published work. In addition, improvements and homogenizations that have occurred to date are discussed. This is the first of three overview papers discussing the results from the $\mathrm{SI}^{2} \mathrm{~N}$ Initiative. The second paper describes the validation of the different available ozone profile measurements (Lambert et al., 2014) and the third paper provides information about and an overview on the merging and homogenizing of different data sets and calculation of long-term trends (Harris et al., 2014). Ground-based ozone profiles, ordered according to the number of available stations, are described in Sect. 2. In Sect. 3, satellite-based ozone profiles are covered. The satellite measurements are organized by measurement techniques; these include solar/stellar-occultation measurements, limb measurements and nadir measurements. A summary, including discussion of possible temporal and spatial coverage problems for the measurement systems, is presented in Sect. 4.

\section{Ground-based measurement systems}

The global map with location of the ground-based instrument systems (ozonesonde, Dobson/Brewer, lidar, FTIR and microwave) is shown in Fig. 1. Ozonesondes and Dobson/Brewer instruments provide the longest record of stratospheric ozone variability (see Fig. 2). Ozonesondes are all weather sounders, and can measure at night and through clouds. Their data quality is good in the lower stratosphere and troposphere where satellites measurement quality is less reliable, and their vertical resolution is much higher than is achievable from remotely sensed measurement. Ozonesondes are inexpensive and easily deployable. Dobson Umkehr measurements have captured evolution of the upper stratospheric ozone prior to the satellite era and still remain the most inexpensive measurement system requiring minimal manpower. Umkehr measurements with Brewer instruments were added later, but they offer fully automated and remotecontrolled operations, and furthermore add spectral UV measurements. Ozone lidar measurements are self-calibrated and provide high vertically resolved measurements with small uncertainties (especially for the low to mid-stratosphere). Ground-based high-resolution FTIR solar absorption measurements do not require an absolute calibration either; the ozone absorption lines are very narrow and are therefore self-calibrated with the reference being the surrounding continuum. This technique has also the advantage of providing precise total columns in addition to vertical information. Ground-based microwave measurements can be made with a time resolution of an hour or less throughout a full diurnal cycle; their calibration is based on temperature, the measurements are insensitive to stratospheric aerosols, and the 


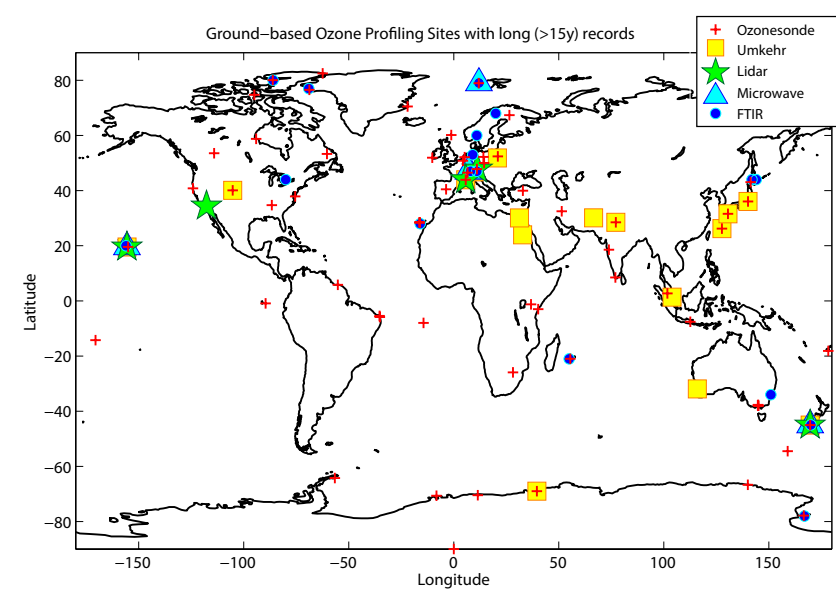

Figure 1. World map with locations of long-term ground-based measurement sites: ozone sounding sites (red plus signs), lidar sites (green stars), microwave sites (light blue triangles), Dobson/Brewer sites with Umkehr measurements (yellow squares), and FTIR sites (dark blue circles).

instruments are nearly fully automated and require less personnel time and other resources to operate than most other ground-based instruments.

\subsection{Ozonesondes}

Ozonesondes are small, lightweight and compact balloonborne instruments, developed for measuring the vertical distribution of atmospheric ozone up to an altitude of about 30$35 \mathrm{~km}$ (see Table 1a). During flight operation, ozonesondes are coupled with standard meteorological radiosondes providing temperature, pressure and wind measurements. The effective vertical resolution of the ozone profile, which is dependent on the balloon ascent rate, is about 100-150 m (see Table $1 \mathrm{~b}$ and Fig. 3a).

There were 66 stations contributing data in the 2000s (Fig. 1). Ozonesonde records provide the longest time series of the vertical ozone distribution throughout both troposphere and stratosphere; some station records start in the 1960s (see Fig. 2 and Table 1c). Most of the profiles are from the electrochemical concentration cell (ECC)-type ozonesonde (Komhyr, 1969) introduced in the early 1970s and adopted by most stations in the global network by the early 1980s. Almost all data in the most recent decade are from ECC sondes. Remaining data are from Brewer-Mast (B-M) sondes (Brewer and Milford, 1960), Japanese carbon iodine cell sondes (KC96) (Kobayashi and Toyama, 1996), and Indian sondes. Prior to the early 1990s, three stations in Eastern Europe flew the GDR (German Democratic Republic) sonde. A majority of the data before 1980 is from $\mathrm{B}-\mathrm{M}$ sondes or similar (both the GDR and Indian sondes are similar in design to the B-M sonde). All five types use the reaction of ozone with potassium iodide in an aqueous solution as the method of ozone detection, but the instrumental layouts are significantly different (e.g., Smit, 2002; Tarasick and Slater, 2008).

When properly prepared and handled, ECC sondes yield profiles with random errors of 3-5\% (1 $\sigma)$ and overall uncertainties of about $5 \%$ in the stratosphere (Kerr et al., 1994; Smit et al., 2007; Deshler et al., 2008; Liu et al., 2009). Two types of ECC sondes are in current use, with minor differences in construction and some variation in recommended concentrations of the sensing solution and of its phosphate buffer. The maximum change in stratospheric response resulting from these systematic differences is on the order of 2-3\% (Smit et al., 2007). Other sonde types have somewhat larger random errors of 5-10\% (Kerr et al., 1994; Parrish et al., 2013).

In early intercomparisons (Attmannspacher and Dütsch, 1970, 1980), the Indian and the GDR sondes showed significantly larger random errors than other sonde types. The largest systematic differences between sondes are in the lower stratosphere, where in early intercomparisons the B$\mathrm{M}$ and GDR sondes read $\approx 5-10 \%$ lower than the ECC and KC sondes (Attmannspacher and Dütsch, 1970, 1980). The Indian sonde has generally shown little bias in the lower stratosphere, but somewhat larger random errors than the other non-ECC sondes. In later intercomparisons differences were smaller: the $\mathrm{KC}$ sondes were biased low by $\approx 5 \%$ in the lower stratosphere, and the B-M sonde generally showed a small low bias as well (Kerr et al., 1994; Smit and Kley, 1998; Deshler et al., 2008).

In the middle stratosphere (below $28 \mathrm{~km}$ ) differences in sonde response are small. As noted above, both systematic and random errors have improved with time, and from 1980 onwards (between the tropopause and $28 \mathrm{~km}$ ) the random error component of sonde measurements, for all types, is generally within $\pm 5 \%$, and systematic biases between them or compared to other ozone sensing techniques are smaller than $\pm 5 \%$ (SPARC, 1998).

Above $28 \mathrm{~km}$ the measurement behavior of the different sonde types is not consistent due to instrumental uncertainties (e.g. pump-flow corrections and sensing solution strength) and cannot be generally characterized. Here, B$M$ sondes show increasing underestimation of ozone with altitude (De Backer et al., 1998; Stübi et al., 2008), while $\mathrm{KC}$ sondes tend to overestimate ozone with increasing altitude (SPARC, 1998; Smit and Straeter, 2004; Deshler et al., 2008). In contrast, the performance of ECC sondes between 28 and $35 \mathrm{~km}$ is still good, overestimating ozone compared to other measurement techniques by less than $5 \%$ (SPARC, 1998; Smit et al., 2007).

However, for ECC sondes recent studies (Johnson et al., 2002; Smit et al., 2007; Deshler et al., 2008) have demonstrated that changes of manufacturer or strength of sensing solution can introduce significant inhomogeneities (up to $\pm 5-10 \%$ ) in long-term sounding records. Such artifacts, like those introduced by changes of sonde type, can be removed through the use of transfer functions derived from 


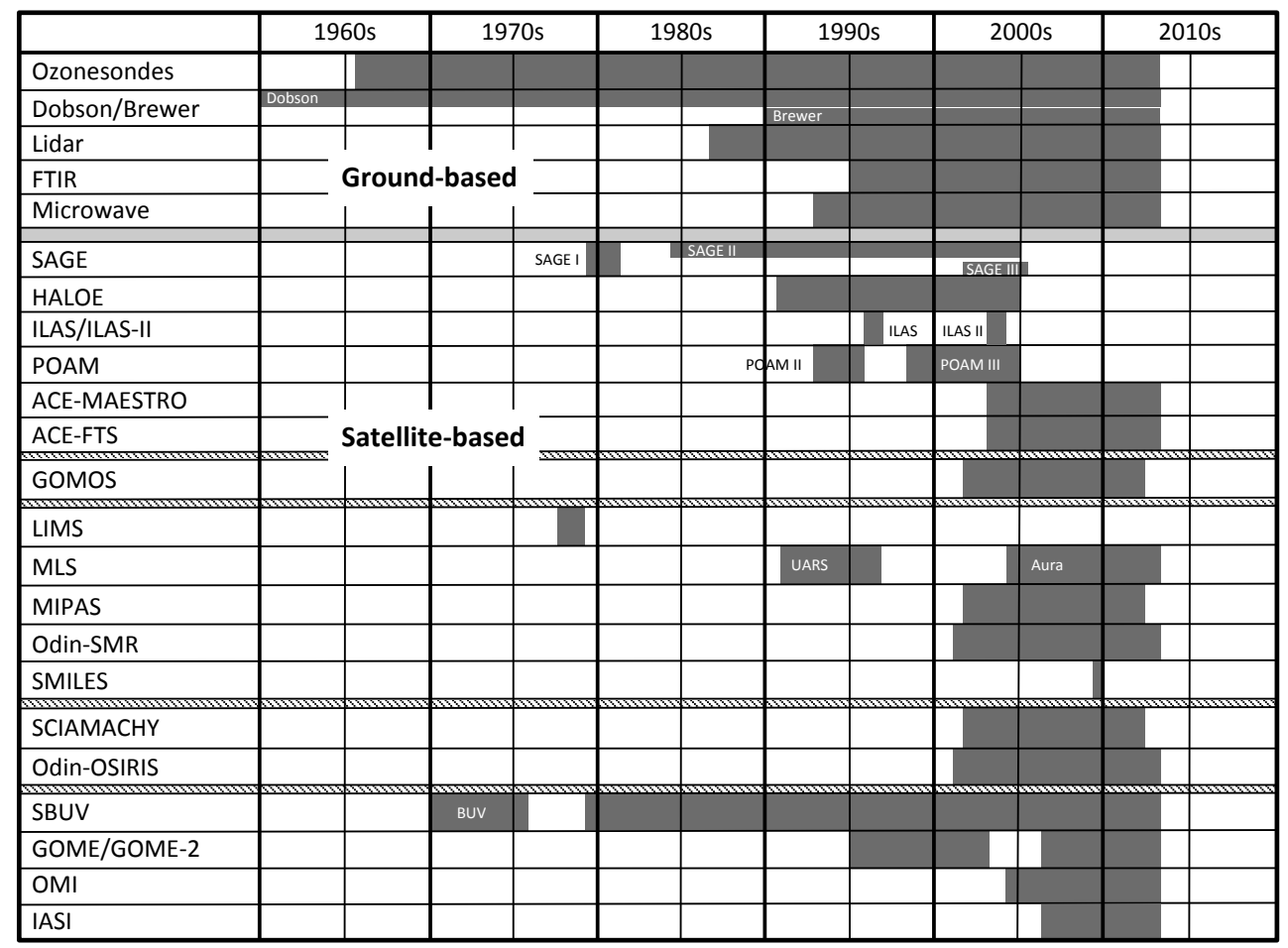

Figure 2. Temporal coverage of the described ground- and satellite-based measurement systems.

intercomparisons in the laboratory or field. Most station long-term records are currently being re-evaluated and homogenized under the Ozonesonde Data Quality Assessment activity of the $\mathrm{SI}^{2} \mathrm{~N}$ Initiative (H. G. J. Smit, personal communication, 2013). This should both reduce overall uncertainties and allow increased confidence in trends derived from ozonesonde data in future assessments.

Ozonesonde profiles are archived by the World Ozone and Ultraviolet Radiation Data Center (WOUDC), the Network for the Detection of Atmospheric Composition Change (NDACC) and the Southern Hemisphere Additional OZonesondes network (SHADOZ) (see Table 1d for more details).

\subsection{Dobson/Brewer}

Dobson and Brewer are ground-based spectrophotometer instruments. The Umkehr measurement is a sequence of morning or afternoon zenith-sky measurements recorded as a relative change of transmission at two spectral channels (Dobson) or photon counts at individual spectral channels (Brewer), all selected in the ultraviolet part of the zenith-sky spectrum. Measurements are taken when the sun elevation changes between $60^{\circ}$ and $90^{\circ}$ solar zenith angle (SZA), and under the assumption of static atmospheric conditions and no clouds in the zenith viewing area. The vertical resolution of an Umkehr ozone profile is $\approx 10 \mathrm{~km}$. Ozone profiles (in Dobson units (DU)) are historically provided in 10 pressure layers, where pressure at the top of the layer is half of the pressure at the bottom, while the tropospheric measurement is one thick layer below $250 \mathrm{hPa}$ (see Table 1a, b). The uncertainty in the retrieved ozone profile is a combination of measurement error (increases with increasing SZA) and smoothing error (about $10-20 \%$ in the troposphere and low stratosphere and $\approx 5 \%$ in middle and upper stratosphere).

The Umkehr record length varies by station; the longest record is from Arosa, Switzerland (starting in 1956; see Table 1c). The latest version of the ozone profile algorithm for processing of Dobson Umkehr data (UMK04) is described in Petropavlovskikh et al. (2005). Although Umkehr profiles show systematic biases in comparisons with other measurements (Nair et al., 2011; Kramarova et al., 2013b), this is of less concern for trend analysis when the UMK04 profile retrievals are used as monthly mean anomalies. However, smoothing errors, especially in the lower stratosphere, create low vertical resolution in the Umkehr retrieved profile and enhance retrieval noise in the lower stratosphere and troposphere. The forward model used to process Brewer Umkehr data (O3BUmkehr v.2.6, http://www.o3soft.eu/o3bumkehr. html) was adapted from the UMK04 model taking into account the different optical characteristics of the Brewer instrument (Petropavlovskikh et al., 2011, see Table 1d).

The Umkehr method uses a technique that minimizes systematic errors of instrumental drifts by normalizing to one of its measurements. Other methods are used to track instrument stability, such as once a month checks of wavelength 
Table 1a. Summary of measurement techniques and lowest and highest covered level for the five ground-based measurement systems and all described satellite measurement systems.

\begin{tabular}{|c|c|c|c|}
\hline Name of instrument & Measurement technique & Covered vertical region: lowest level & Covered vertical region: highest level \\
\hline \multicolumn{4}{|c|}{ Ground-based measurement systems } \\
\hline Ozonesondes & Electrochemical conversion of ozone & Surface & $30-35 \mathrm{~km}$ altitude (bursting point of balloon) \\
\hline Dobson/Brewer & Umkehr, ground-based, UV part of the spectrum & Tropospheric layer: surface to $\approx 250 \mathrm{hPa}$ & To top of atmosphere \\
\hline Lidar & $\begin{array}{l}\text { Differential Absorption Lidar (DIAL), ground-based, } \\
\text { UV laser radiation }\end{array}$ & Tropopause & $45-55 \mathrm{~km}$ depending on the lidar systems \\
\hline FTIR & $\begin{array}{l}\text { Ground-based solar absorption measurements in the infrared. } \\
\text { The ozone profile is retrieved from the pressure-broadened line } \\
\text { shape. }\end{array}$ & Surface & $40-45 \mathrm{~km}$ \\
\hline Microwave & $\begin{array}{l}\text { Measurement of the emission spectrum of a thermally ex- } \\
\text { cited rotational transition of ozone in the millimeter wave- } \\
\text { length range. The ozone profile is retrieved from the pressure- } \\
\text { broadened line shape. }\end{array}$ & Typically $\approx 20 \mathrm{~km}$ & $\begin{array}{l}\text { Varies by spectral line frequency. Up to } 72 \mathrm{~km} \text { at night, and } \\
66 \mathrm{~km} \text { during the day for the transition at } 110.836 \mathrm{GHz} \text {. }\end{array}$ \\
\hline \multicolumn{4}{|c|}{ Satellite-based measurement systems } \\
\hline SAGE & Solar occultation & Tropopause or $10 \mathrm{~km}$ whichever is lower & $55 \mathrm{~km}$ \\
\hline HALOE & $\begin{array}{l}\text { Solar occultation instrument; } 9.4 \text { to } 10.4 \mu \mathrm{m} \text { ozone channel } \\
\text { (SPARC, 1998) }\end{array}$ & Cloud top or to just below the tropopause & To near $0.005 \mathrm{hPa}$ for temperature and ozone \\
\hline ILAS/ILAS-II & Satellite-based, solar occultation & Cloud top: $\approx 10 \mathrm{~km}$ & To top of atmosphere \\
\hline POAM & Solar occultation in the UV-V is spectral range & $5 \mathrm{~km}$ (or cloud top) & $60 \mathrm{~km}$ \\
\hline ACE-MAESTRO & Solar occultation spectrophotometry in the Chappuis band & $\approx 5 \mathrm{~km}$ & $\approx 35 \mathrm{~km}$ \\
\hline ACE-FTS & Satellite-based, solar occultation, infrared spectrum & Cloud tops $(\approx 5 \mathrm{~km})$ & $95 \mathrm{~km}$ \\
\hline GOMOS & Satellite-based stellar occultation instrument in UV-VIS-NIR & Typically cloud top, however, lowest valid altitude $\approx 15 \mathrm{~km}$ & $100 \mathrm{~km}$ \\
\hline LIMS & $\begin{array}{l}\text { Satellite-based instrument, limb-infrared emission experiment; } \\
9 \text { to } 10 \text { micrometer band for ozone }\end{array}$ & 250 to $300 \mathrm{hPa}$ or higher cloud top & To near $0.01 \mathrm{hPa}$ for $\mathrm{T}$ and ozone \\
\hline UARS MLS & Microwave limb emission sounding (satellite) & $100 \mathrm{hPa}$ & $0.2 \mathrm{hPa}$ \\
\hline Aura MLS & Microwave limb emission sounding (satellite) & $215 \mathrm{hPa}$ & $0.02 \mathrm{hPa}$ \\
\hline MIPAS & Satellite-based mid-infrared limb emission & $\begin{array}{l}\text { It depends on the measurement mode. Most data are in nominal } \\
\text { observation mode: } \\
6 \mathrm{~km} \text { (or cloud top) for } 2002 \text { to } 2004 \\
7-12 \mathrm{~km} \text { (following tropopause height) or cloud top for } \\
2005 \text { to } 2012 \text {; } \\
\text { Middle/upper atmosphere modes: above } 20 \text { or above } 40 \mathrm{~km} \\
\text { These are nominal numbers; real numbers can vary. }\end{array}$ & $\begin{array}{l}\approx 68 / 72 \mathrm{~km}(2002-2004 / 2005-2012) \text { in nominal observation } \\
\text { mode; up to } 100 \mathrm{~km} \text { in middle/upper atmosphere modes. }\end{array}$ \\
\hline Odin-SMR & Microwave limb emission sounding (satellite) & $\approx 12 \mathrm{~km}$ (poles), $17-18 \mathrm{~km}$ (mid-latitudes) & $\approx 60 \mathrm{~km}$ \\
\hline SMILES & $\begin{array}{l}\text { Submillimeter-wave limb emission sounding (onboard } \\
\text { the International Space Station) }\end{array}$ & $\approx 16 \mathrm{~km}$ & $\approx 95 \mathrm{~km}$ \\
\hline SCIAMACHY & UV-V is limb scatter & Tropopause $(10 \mathrm{~km})$ & Mesosphere $(60 \mathrm{~km})$ \\
\hline Odin-OSIRIS & Satellite based, UV-visible, limb scatter & Cloud tops & $55 \mathrm{~km}$ \\
\hline SBUV & Satellite-based nadir-view backscattered UV radiation & Surface & Top of atmosphere \\
\hline GOME/GOME-2 & $\begin{array}{l}\text { Optimal Estimation method, satellite-based instrument looking } \\
\text { in nadir direction, UV-VIS part of the spectrum }\end{array}$ & Surface & Top of atmosphere \\
\hline OMI & UV-VIS nadir spectrometer & Surface & Up to $0.3 \mathrm{hPa}$ \\
\hline IASI & Fourier transform spectrometer, thermal infrared & Tropospheric layer or lower if thermal contract is good & Total columns (sensitivity up to around $45 \mathrm{~km}$ ) \\
\hline
\end{tabular}

registration by using standard discharge lamps, ratio of measurements at several spectral channels (for Brewer instruments, daily), and optical wedge calibration produced during Dobson intercomparisons (every 4 years). These methods track degradation of the optical system. Effects of ozone cross-section values and uncertainties of stray light effects on Dobson and Brewer Umkehr ozone profiles are discussed in Petropavlovskikh et al. (2011) and WMO (2008). The replacement of an instrument at the station can cause a step change in the Umkehr record due to the difference in the out-of-band contribution that is specific to each instrument. Thus, additional homogenization of the record may be required (Zanis et al., 2006; Miyagawa et al., 2009). In addition, interference from optically thick aerosol loading (volcanic) at Umkehr spectral channels results in systematic errors that can be as large as $10-15 \%$. Therefore, about two years of data are typically removed after the Pinatubo (1991) and El Chichon (1982) volcanic eruptions. Data from 28 stations with current Umkehr measurements and of 58 stations with historical Umkehr measurements are archived at WOUDC, Toronto, Canada (see Table 1d for the URL).

\subsection{Lidar}

Lidar (light detection and ranging) is an active, remotesensing instrument that uses the interaction between a laser beam and atmospheric molecules and particles. Ozone lidar measurements are performed using the DIfferential Absorption Lidar method (DIAL), which is based on the absorption of ultraviolet radiation by ozone and requires the emission of two laser wavelengths (so-called "on" and "off" wavelengths) characterized by different ozone absorption cross sections (Pelon et al., 1986; Godin et al., 1989; McDermid et al., 1990). The use of pulsed lasers provides range resolved measurements. Ozone DIAL systems include one or two lasers, depending on the technique used for the generation of the off wavelength, an optical receiving system that includes a telescope for the collection of the laser light, a spectrometer or filters for the separation of the received wavelengths and an electronic data acquisition system. In the case of stratospheric ozone, photon counting is generally used for the acquisition of the lidar signal in order to provide high sensitivity and low noise. The ozone number density is commonly retrieved from the difference of the slopes of the logarithm of the lidar signals corrected for the background noise and saturation affecting large signals originating from 
Table 1b. Summary of the vertical resolution, native vertical grid and native ozone units for the five ground-based measurement systems and all described satellite measurement systems.

\begin{tabular}{|c|c|c|c|c|}
\hline Name of instrument & Vertical resolution* & Representation grid & Native vertical grid* & Native ozone units* \\
\hline \multicolumn{5}{|c|}{ Ground-based measurement systems } \\
\hline Ozonesondes & $\begin{array}{l}100-150 \mathrm{~m} \\
\text { (at ascent rate of } 5 \mathrm{~m} \mathrm{~s}^{-1} \text { and response time of } \\
20-30 \mathrm{~s} \text { ) }\end{array}$ & $100-200 \mathrm{~m}$ & Flight time & Partial ozone pressure in milli-pascal $(\mathrm{mPa})$ \\
\hline Dobson/Brewer & $\approx 10 \mathrm{~km}$ & $\approx 10 \mathrm{~km}$ & Pressure levels & Dobson units (DU) \\
\hline Lidar & $\begin{array}{l}\text { The resolution varies as a function of altitude } \\
\text { from } 0.5 \mathrm{~km} \text { below } 20 \mathrm{~km}, 2 \mathrm{~km} \text { around } 30 \mathrm{~km} \\
\text { to more than } 5 \mathrm{~km} \text { above } 45 \mathrm{~km} \text {. }\end{array}$ & Depending on the systems: 0.15 or $0.3 \mathrm{~km}$ & Altitude levels & Ozone number density $\left(\mathrm{cm}^{-3}\right)$ \\
\hline \multirow[t]{2}{*}{ FTIR } & $\approx 8-10 \mathrm{~km}$ for the ground $\approx 9 \mathrm{~km}$ layer & $\begin{array}{l}\text { In NDACC HDF archived files: the retrieval } \\
\text { grid contains, depending on the station, about } \\
41 \text { to } 47 \text { levels (from ground to } 100 \mathrm{~km} \text { ). }\end{array}$ & Pressure levels & Volume mixing ratio (ppmv) \\
\hline & $\begin{array}{l}\approx 8 \mathrm{~km} \text { for the lower and middle stratospheric } \\
\text { layer } \\
\approx 15-20 \mathrm{~km} \text { for the upper stratospheric layer } \\
(\approx 28-45 \mathrm{~km})\end{array}$ & & & (provided also as partial columns $\left(\mathrm{mol} \mathrm{cm}^{-2}\right)$ ) \\
\hline \multirow[t]{2}{*}{ Microwave } & $\begin{array}{l}\text { Varies by instrument, typ. } 8-10 \mathrm{~km} \text {, from } \\
\approx 20 \text { to } 40 \mathrm{~km} \text {, then increasing to } \approx 17 \mathrm{~km} \text { at } \\
\approx 60 \mathrm{~km} \text {, see Sec. } 2.5\end{array}$ & Varies by instrument. Typ. $\approx 2 \mathrm{~km}$ intervals & Pressure levels & Volume mixing ratio (ppmv) \\
\hline & & & $\begin{array}{l}\text { (grid on which data are provided varies by } \\
\text { instrument) }\end{array}$ & \\
\hline \multicolumn{5}{|c|}{ Satellite-based measurement systems } \\
\hline SAGE & $1 \mathrm{~km}$ & $1 \mathrm{~km}$ & Altitude levels & Ozone number density $\left(\mathrm{cm}^{-3}\right)$ \\
\hline HALOE & $\begin{array}{l}\text { Measurement: } 1.8 \mathrm{~km} \text { instantaneous field of } \\
\text { view (IFOV); retrieval resolution is } 2.3 \mathrm{~km}\end{array}$ & $2.3 \mathrm{~km}$ vertical resolution & $\begin{array}{l}\text { Solar zenith angle or apparent altitude, sampled } \\
\text { every } 0.3 \mathrm{~km} \text {. } \\
\text { (provided also on pressure and associated } \\
\text { hydrostatic altitude levels) }\end{array}$ & $\begin{array}{l}\text { Transmission vs. solar zenith angle or apparent } \\
\text { altitude } \\
\text { (provided as volume mixing ratio (ppmv)) }\end{array}$ \\
\hline ILAS/ILAS-II & $\begin{array}{l}\text { ILAS: } \approx 1.9 \mathrm{~km} \\
\text { ILAS-II: } \approx 1.6 \mathrm{~km}\end{array}$ & $\approx 1 \mathrm{~km}$ & Tangent height (in km) & Volume mixing ratio (ppmv) \\
\hline POAM & $\approx 1.5 \mathrm{~km}$ & $\approx 1 \mathrm{~km}$ & Altitude levels & Ozone number density $\left(\mathrm{cm}^{-3}\right)$ \\
\hline ACE-MAESTRO & $\approx 1.2 \mathrm{~km}$ & $\approx 1.0 \mathrm{~km}$ & Tangent levels & $\begin{array}{l}\text { Concentration }\left(\mathrm{mol} \mathrm{cm}^{-2}\right) \\
\text { (provided as volume mixing ratio }(\mathrm{ppmv}))\end{array}$ \\
\hline ACE-FTS & $\approx 3-4 \mathrm{~km}$ & $\begin{array}{l}1 \mathrm{~km} \text { (interpolated to standard grid) and } \approx 3- \\
4 \mathrm{~km} \text { (as measured) }\end{array}$ & Altitude levels & Volume mixing ratio (ppmv) \\
\hline \multirow[t]{2}{*}{ GOMOS } & Resolution of ozone measurements: & $\begin{array}{l}\text { Vertical sampling resolution: about } 0.5-1.7 \mathrm{~km} \text {. } \\
\text { Variable for each profile. }\end{array}$ & Altitude levels & Ozone number density $\left(\mathrm{cm}^{-3}\right)$ \\
\hline & $\begin{array}{l}2 \mathrm{~km} \text { below } 30 \mathrm{~km} \\
3 \mathrm{~km} \text { below } 40 \mathrm{~km} \\
\text { smooth transition between } 30-40 \mathrm{~km}\end{array}$ & & & \\
\hline LIMS & $\begin{array}{l}\text { Measurement: } 1.8 \mathrm{~km} \text { instantaneous field of } \\
\text { view (IFOV); Retrieval: } 3.7 \mathrm{~km}\end{array}$ & $\begin{array}{l}\text { Level } 2 \text { data are provided every } 0.88 \mathrm{~km} \text {, having } \\
\text { a vertical resolution of } \approx 3.7 \mathrm{~km}\end{array}$ & $\begin{array}{l}\text { Pressure levels } \\
\text { (data are also provided on altitude levels) }\end{array}$ & Volume mixing ratio (ppmv) \\
\hline UARS MLS & $\begin{array}{l}3.5-4 \mathrm{~km} \text { in the stratosphere and } 5-8 \mathrm{~km} \text { in the } \\
\text { mesosphere }\end{array}$ & $\begin{array}{l}3 \mathrm{~km} \text { ( } 6 \text { levels per decade change in pressure for } \\
\text { stratosphere) }\end{array}$ & Pressure levels & Volume mixing ratio (ppmv) \\
\hline Aura MLS & $\begin{array}{l}2.5-3 \mathrm{~km} \text { in upper troposphere to lower meso- } \\
\text { sphere, } 4 \text { to } 6 \mathrm{~km} \text { in upper mesosphere }\end{array}$ & $\begin{array}{l}\approx 3 \mathrm{~km} \text { ( } 6 \text { levels per decade change in pressure) } \\
\text { for pressures larger than } 0.1 \mathrm{hPa} \text {; grid resolution } \\
\text { degrades by a factor of two for pressures less } \\
\text { than } 0.1 \mathrm{hPa} \text {. }\end{array}$ & Pressure levels & Volume mixing ratio (ppmv) \\
\hline \multirow[t]{3}{*}{ MIPAS } & $\begin{array}{l}\text { Optimized resolution nominal mode (years } \\
\text { 2005-2012) }\end{array}$ & $\begin{array}{l}\text { IMK: retrieval and data representation grid for } \\
\text { reduced resolution nominal mode is } 1 \mathrm{~km} \text { from } \\
4-44 \mathrm{~km}, 2 \mathrm{~km} \text { from } 44-70 \mathrm{~km} ; 5 \mathrm{~km} \text { above }\end{array}$ & IMK: Altitude levels & Volume mixing ratio (ppmv) \\
\hline & $\begin{array}{l}\text { IMK: } 2.4-3.6 \mathrm{~km} \text { (reduced resolution nominal } \\
\text { mode) }\end{array}$ & $\begin{array}{l}\text { ESA processor: grid of the measured tangent } \\
\text { altitudes }\end{array}$ & $\begin{array}{l}\text { (ESA: provides pressure levels where the re- } \\
\text { trieved pressure corresponds to the measured } \\
\text { tangent altitude) }\end{array}$ & \\
\hline & $\begin{array}{l}\text { ESA processor: } 2 \mathrm{~km} \text { at } 10 \mathrm{~km}, 3.2 \mathrm{~km} \text { at } 30 \mathrm{~km} \text {, } \\
5 \mathrm{~km} \text { at } 70 \mathrm{~km} \text {, mostly independent on atmo- } \\
\text { spheric conditions } \\
\text { Full resolution mode (years 2002-2004) } \\
\text { IMK: } 3.5 \mathrm{~km} \text { at } 10 \mathrm{~km}, 5 \mathrm{~km} \text { at } 42 \mathrm{~km}, 8 \mathrm{~km} \text { at } \\
60 \mathrm{~km} \text {. } \\
\text { ESA: } 4 \mathrm{~km} \text { at } 10 \mathrm{~km}, 5 \mathrm{~km} \text { at } 30 \mathrm{~km}, 8 \mathrm{~km} \text { at } \\
70 \mathrm{~km} \text {. }\end{array}$ & $\begin{array}{l}\text { MIPAS2D: } 3 \mathrm{~km} \text { from } 6 \text { to } 42 \text { then } 47,52,60 \\
\text { and } 68 \mathrm{~km}\end{array}$ & & \\
\hline Odin-SMR & $2.5-3.5 \mathrm{~km}$ & $1.5 \mathrm{~km}$ and $3 \mathrm{~km}$ & $\begin{array}{l}\text { Pointing information is retrieved from pressure } \\
\text { broadened spectral lines } \\
\text { (provided on altitude levels: altitude-pressure- } \\
\text { temperature information provided for interpola- } \\
\text { tion between grids) }\end{array}$ & Volume mixing ratio (ppmv) \\
\hline SMILES & $2-4 \mathrm{~km}$ & $2.5 \mathrm{~km}$ & Altitude levels & Volume mixing ratio (ppmv) \\
\hline SCIAMACHY & $3-5 \mathrm{~km}$ & $1 \mathrm{~km}$ & Geometric height $(\mathrm{km})$ & Ozone number density $\left(\mathrm{cm}^{-3}\right)$ \\
\hline Odin-OSIRIS & $\approx 1.5 \mathrm{~km}$ in UTLS and $2 \mathrm{~km}$ higher up & $\approx 1 \mathrm{~km}$ & Altitude levels & Ozone number density $\left(\mathrm{cm}^{-3}\right)$ \\
\hline SBUV & $\begin{array}{l}\approx 6 \mathrm{~km} \text { at } 3 \mathrm{hPa} \\
\approx 15 \mathrm{~km} \text { in troposphere and lower mesosphere }\end{array}$ & $3.2 \mathrm{~km}$ & Pressure levels & $\begin{array}{l}\text { Dobson units (DU) } \\
\text { (provided also as volume mixing ratio (ppmv)) }\end{array}$ \\
\hline GOME/GOME-2 & $\approx 7-15 \mathrm{~km}$ & $\approx 4 \mathrm{~km}$ & Pressure levels & Dobson units (DU) \\
\hline OMI & $6-10 \mathrm{~km}$ & $2-5 \mathrm{~km}$ & Pressure levels & Dobson units (DU) \\
\hline IASI & $\approx 7 \mathrm{~km}$ & $\begin{array}{l}1 \mathrm{~km} \text { up to } 40 \mathrm{~km} \\
2 \mathrm{~km} \text { from } 40 \mathrm{~km} \text { to } 60 \mathrm{~km}\end{array}$ & Altitude levels & $\begin{array}{l}\text { Ozone number density }\left(\mathrm{cm}^{-3}\right) \\
\text { (provided as volume mixing ratio (ppmv) or } \\
\text { ozone partial columns (DU)) }\end{array}$ \\
\hline
\end{tabular}

* specified by instrument/averaging kernel 
Table 1c. Summary of the covered time period, the number of measurements and the time for measurements for the five ground-based measurement systems and all described satellite measurement systems.

\begin{tabular}{|c|c|c|c|}
\hline Name of instrument & Covered time period & $\begin{array}{l}\text { Average number of measurements } \\
\text { (per day/per week/per month) }\end{array}$ & Measurement time of day \\
\hline \multicolumn{4}{|c|}{ Ground-based measurement systems } \\
\hline Ozonesondes & $\begin{array}{l}\text { Varies from station to station, longest record from mid 1960s, } \\
\text { early } 1970 \mathrm{~s}\end{array}$ & $1-2$ vertical ozone soundings per week & $\begin{array}{l}\text { Ozonesondes are usually launched at daytime before about } \\
\text { noon time }\end{array}$ \\
\hline Dobson/Brewer & $\begin{array}{l}\text { Varies from station to station, longest record from Arosa, } \\
\text { Switzerland: 1956-present }\end{array}$ & $\begin{array}{l}\text { Average is about } 15 \text { per months }(\approx 200 \text { per year; depending on } \\
\text { station and season) }\end{array}$ & $\begin{array}{l}\text { Sunrise and sunset between } 70 \text { and } 90^{\circ} \text { solar zenith angle (SZA) } \\
\text { (only with clear sky) }\end{array}$ \\
\hline Lidar & $\begin{array}{l}\text { Varies from station to station, the longest records start in the } \\
\text { late 1980s (OHP, France; Hohenpeissenberg, Germany; Table } \\
\text { Mountain, USA) }\end{array}$ & $\begin{array}{l}\text { Up to } 20 \text { measurements per month (depending on weather con- } \\
\text { ditions) }\end{array}$ & Nighttime (only with clear sky) \\
\hline FTIR & Varies from station to station, usually 1995 -present. & Mean of all stations: $\approx 2.5$ per day ( 7 per week; 15 per month) & Daytime (only with clear sky). \\
\hline Microwave & $\begin{array}{l}\text { Sep 1992-present (Lauder), Jun 1995-present (Mauna Loa), } \\
\text { 2000-present (Payerne). Other records back to 1990's may be } \\
\text { available. }\end{array}$ & 4 to 48 profiles per day in suitable weather, depending on station & Day- and nighttime (only with clear sky) \\
\hline \multicolumn{4}{|c|}{ Satellite-based measurement systems } \\
\hline \multirow[t]{3}{*}{ SAGE } & SAGE I: Feb 1979-Nov 1981 & \multirow[t]{3}{*}{ Up to 15 sunrise and 15 sunset events per day } & \multirow[t]{3}{*}{ Sunrise/sunset } \\
\hline & SAGE II: Oct 1984-Jul 2005 & & \\
\hline & SAGE III: Dec 2001-Mar 2006 & & \\
\hline HALOE & Oct 1991-Nov 2005 & Up to 15 sunrise and 15 sunset events per day & Sunrise/sunset \\
\hline \multirow[t]{2}{*}{ ILAS/ILAS-II } & ILAS: 30 Oct 1996-29 Jun 1997 & ILAS: 28 profiles per day (14 sunrise and 14 sunset profiles) & \multirow[t]{2}{*}{ Sunrise/sunset } \\
\hline & ILAS-II: 2 Apr 2003-24 Oct 2003 & ILAS-II: 28 profiles per day ( 14 sunrise and 14 sunset profiles) & \\
\hline \multirow[t]{2}{*}{ POAM } & POAM II: Sep 1993-Nov 1996 & 14 measurements per day in each hemisphere & $\begin{array}{l}\text { Measurement performed at local sunset in } \mathrm{NH} \text {, but in the } \mathrm{SH} \\
\text { they are at local sunset in the winter and local sunrise in the } \\
\text { summer. }\end{array}$ \\
\hline & POAM III: Apr 1998-Nov 2005 & & \\
\hline ACE-MAESTRO & Feb 2004-present & Up to 30 profiles per day & Sunrise/sunset \\
\hline ACE-FTS & Feb 2004-present & Up to 30 profiles per day & Sunrise/sunset \\
\hline \multirow[t]{2}{*}{ GOMOS } & Aug 2002-Apr 2012 & Daily: $100-200$ profiles & \multirow[t]{2}{*}{ Nighttime (around 22:00) } \\
\hline & $\begin{array}{l}\text { Reduced number of measurements due to } \\
\text { instrumental problems in year } 2005 \text { and since Oct } 2011\end{array}$ & $\begin{array}{l}\text { Monthly: } 3000-6000 \text { profiles } \\
\text { Yearly: } 36000-72000 \text { profiles }\end{array}$ & \\
\hline LIMS & Oct 1978-May 1979. & $\begin{array}{l}\approx 3000 \text { profiles per day (the LIMS observation duty cycle was } \\
\text { of the order of } 5 \text { days on and one day off for most of its mission } \\
\text { life) }\end{array}$ & $\begin{array}{l}\text { LIMS operated in a sun-synchronous mode, taking its tangent } \\
\text { point scans at about } 1300 \text { and } 2300 \mathrm{~h} \text { (at the Equator), but with } \\
\text { little change of local time with latitude until reaching high lati- } \\
\text { tudes. }\end{array}$ \\
\hline UARS MLS & Sep 1991-Jul 1999 & $\approx 1350$ profiles/day & $\begin{array}{l}\text { Day and night measurements are routinely performed around } \\
\text { the orbit, with all local times covered at any given latitude dur- } \\
\text { ing each satellite yaw cycle (every } 36 \text { days on average) }\end{array}$ \\
\hline Aura MLS & Aug 2004-present & $\approx 3500$ profiles/day & $\begin{array}{l}\text { Two local times are sampled every orbit at any given latitude, } \\
\text { daytime and nighttime, with local times typically near 13:00- } \\
\text { 14:00 and near 01:00-02:00 for non-polar latitudes }\end{array}$ \\
\hline MIPAS & Jun 2002-Apr 2012 with gaps in 2004 & $\begin{array}{l}\approx 1400 \text { profiles/day (optimized resolution phase, } \\
\text { nominal mode) } \\
\approx 1050 \text { profiles/day (full resolution phase, nominal mode) }\end{array}$ & 10:00 and 22:00 local time \\
\hline Odin-SMR & Nov 2001-present & $\begin{array}{l}\text { In the stratospheric mode, Odin measures up to (almost) } 1000 \\
\text { vertical profiles per observation day based on up to } \approx 65 \text { scans } \\
\text { per orbit and } 14-15 \text { orbits per observation day. There were } 10 \\
\text { observation days per month before Apr } 2007 \text { (every third day), } \\
15 \text { days per month since } 2007 \text { (every other day) }\end{array}$ & Day- and nighttime (thermal emission measurement). \\
\hline SMILES & Oct 2009-Apr 2010 & $\approx 1600$ per day & Day- and nighttime measurements \\
\hline SCIAMACHY & Aug 2002-Apr 2012 & $\approx 1400$ measurements per day & Daytime measurements only. \\
\hline Odin-OSIRIS & Nov 2001-present & $\begin{array}{l}\text { OSIRIS duty cycle on Odin changed in } 2007 \text {, so scans (between } \\
-60 \text { and } 60^{\circ} \text { ) are reported in pairs (pre-2007 and post-2007): } \\
\text { Average of } 75 / 150 \text { per day ( } 450 / 900 \text { per week; } 2000 / 4000 \text { per } \\
\text { month) }\end{array}$ & $\begin{array}{l}\text { Only a.m. data are included in the } \mathrm{SI}^{2} \mathrm{~N} \text { analysis, typically mea- } \\
\text { sured between } 05: 30 \text { and } 07: 30 \text {, local time. }\end{array}$ \\
\hline SBUV & $\begin{array}{l}\text { Oct } 1978 \text {-present continuous coverage; } 1970-1976 \text { NOAA- } 4 \\
\text { coverage, partial coverage after mid-1972. }\end{array}$ & $\approx 1100$ per day & Daytime measurements only. \\
\hline \multirow[t]{3}{*}{ GOME/GOME-2 } & GOME: 1995-2003 & \multirow[t]{3}{*}{$\approx 20000$ measurements per day } & \multirow[t]{3}{*}{ Daytime measurements only. } \\
\hline & GOME-2A: 2006-present & & \\
\hline & GOME-2B: 2012-present & & \\
\hline OMI & 2004-present & $\approx 140000$ measurements per day & Daytime measurements only. \\
\hline IASI & 2007-present & $\begin{array}{l}\approx 1.2 \times 10^{6} \text { measurement per day (about } 50 \% \text { are cloud } \\
\text { contaminated) }\end{array}$ & $\begin{array}{l}\text { Two overpasses per day at every location (around } 09: 30 \text { and } \\
21: 00 \text {, local time) }\end{array}$ \\
\hline
\end{tabular}

lowermost altitudes. A correction is applied corresponding to differential terms linked to molecular and aerosol scattering, and absorption by other atmospheric constituents (e.g. $\mathrm{NO}_{2}$, $\mathrm{SO}_{2}$ ).

The DIAL technique does not require any calibration and the laser wavelengths are chosen such that the correction term represents less than $10 \%$ of the ozone number density derived from the slope of the lidar signal in the altitude range of interest. When stratospheric aerosol loading is large, such as after cataclysmic volcanic eruptions, this condition is not fulfilled and DIAL measurements are locally perturbed at the altitude of the aerosols. In such conditions, two additional wavelengths corresponding to the first Stokes vibrational Raman scattering of the laser radiation by atmospheric nitrogen can be detected and the Raman lidar signal is used to retrieve ozone (McGee et al., 1993).

Most lidar measurements are performed during the night and averaged over several hours, resulting in a horizontal resolution of 50 to $250 \mathrm{~km}$ over the whole altitude range of the measurement, depending on atmospheric conditions. The vertical resolution decreases as a function of altitude ranging from several hundred meters at lower altitudes to several kilometers above $40 \mathrm{~km}$ (Table 1a, b; Fig. 3a). The systematic uncertainty ranges from a few percent below $20 \mathrm{~km}$ to more than 10-15\% above $45 \mathrm{~km}$ (Godin-Beekmann et al., 2003). Ozone lidar measurements are self-calibrated. 
Table 1d. Summary of the latest data version, URLs where data are available, and information about references in the $\mathrm{SI}^{2} \mathrm{~N}$ special issue for the five ground-based measurement systems and all described satellite measurement systems.

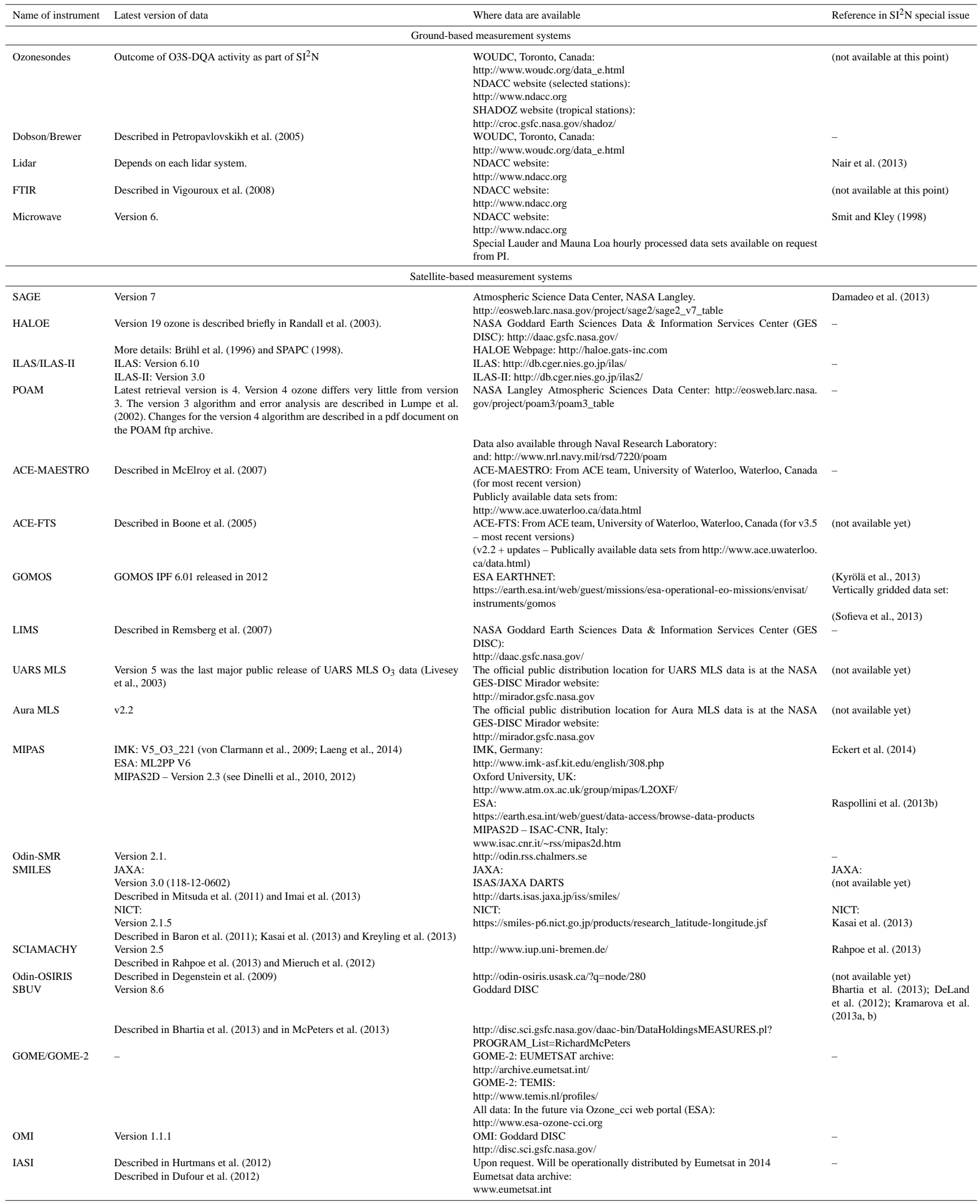



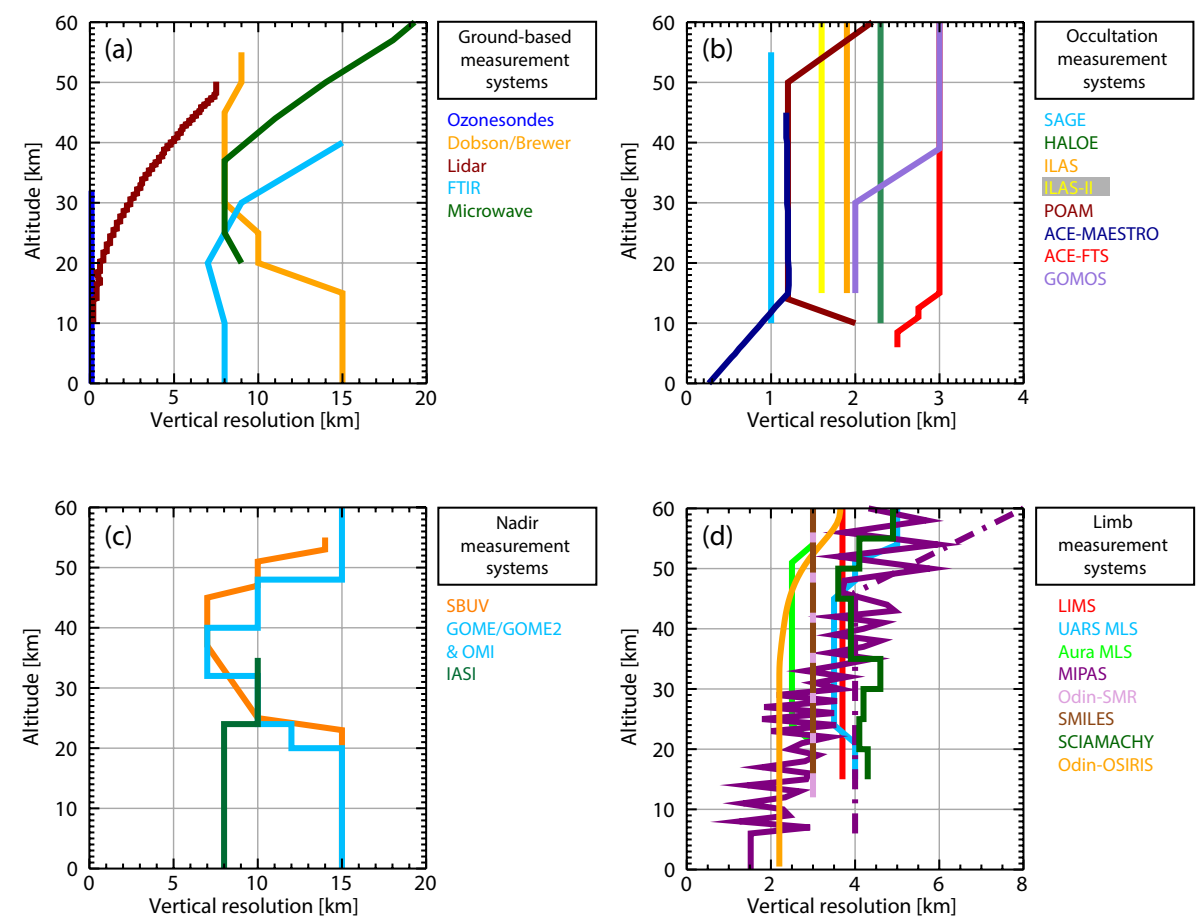

Figure 3. Vertical resolution shown as function of altitude for each of the described instruments systems: (a) ground-based instruments, (b) solar/stellar occultation instruments, (c) nadir-measuring instruments, and (d) limb-measuring instruments. The SMILES profile in panel (d) is shown as a brown dashed line that is plotted on top of the ODIN-SMR (light purple). Note that there are two profiles shown for MIPAS in panel (d): the solid purple line represents the KIT retrieval, and the dash-dotted purple line represents the Bologna retrieval. The oscillating altitude resolution of the MIPAS KIT profile is a consequence of the evaluation of the averaging kernels on a vertical grid finer than the tangent altitude spacing: the vertical resolution is best at the tangent altitudes and coarsest between the tangent altitudes. Retrieval resolution for the Oxford and ESA processors is comparable to the KIT results; however, a courser grid is used for the retrieval and thus it does not show the oscillating features of the KIT processor. For more detail on the different MIPAS retrievals see Sect. 3.3.4.

However, measurement stability can be affected by instrumental artifacts such as alignment error, changes in the intensity of the lidar signals due to varying laser power, or changes in weather conditions (Godin-Beekmann et al., 2003).

There are twelve stratospheric ozone lidar instruments operational globally at this point (see Fig. 1), with the longest continuous records starting in the late 1980s (Steinbrecht et al., 2009). Data are archived in the NDACC database (see Table 1d for the URL).

\subsection{FTIR}

Ground-based FTIR (Fourier transform infrared spectroscopy) solar absorption measurements are performed over the $600-4500 \mathrm{~cm}^{-1}$ spectral range, under clear-sky conditions using primarily high-resolution spectrometers such as the Bruker 120M (or $125 \mathrm{M}$ ) or Bruker 120HR (or 125HR). The spectrometers can achieve a spectral resolution of 0.0035 and $0.002 \mathrm{~cm}^{-1}$, respectively. The advantage of the FTIR technique is that, for atmospheric gases such as ozone which have very narrow lines, an absolute calibration is not needed; the ozone absorption signatures are self-calibrated with the reference being the surrounding continuum. Nevertheless, for the determination of absorber profiles and of vertical trends, especially in the upper-stratosphere, it is important to regularly monitor the instrumental line-shape. This is achieved with gas cell measurements (Hase et al., 1999).

In addition to total columns, low-vertical-resolution profiles can be obtained from the temperature and pressure dependence of the absorption line shapes. Two profile retrieval algorithms are widely used, PROFITT9 (Hase, 2000) and SFIT2 (Pougatchev et al., 1995); both are based on the optimal estimation method (Rodgers, 2000). A European FTIR network has been optimized by using a common retrieval strategy to derive ozone trends (1995-2005) in 4 layers (Vigouroux et al., 2008), one in the troposphere and three in the stratosphere, up to about $45 \mathrm{~km}$ (Table 1a, b). Thus, a high degree of freedom for the signal (DOFS $\approx 4.5$ ) is achieved with the use of the $1000-1005 \mathrm{~cm}^{-1}$ window (Barret et al., 2002). The random error on total columns is about 2-4\% (García et al., 2012; Vigouroux et al., 2008); the leading error source being the temperature. The estimated random error on the ozone partial columns can vary a little depending on the station (different instrument, ozone natural variability impacting the smoothing error). For example, at 
Kiruna the random error for the layers ground- $10 \mathrm{~km}, 10$ $18 \mathrm{~km}, 18-27 \mathrm{~km}$, and $27-42 \mathrm{~km}$ are $10,7,9$, and $6 \%$, respectively (Vigouroux et al., 2008). The smoothing error is dominant in the two lowest layers, whereas the temperature error dominates in the middle and upper stratosphere. Further improvement (on-going research, not applied to the NDACC network yet) can be achieved by retrieving a simultaneous temperature profile, thus reducing the total column random error to less than $1 \%$, and the upper stratospheric error to $3 \%$ (García et al., 2012). The systematic error is dominated by the uncertainties of the spectroscopic parameters (line intensity and air broadening coefficient). The systematic error due to the line intensity uncertainty was estimated to $2-3 \%$ (Barret et al., 2003; Schneider et al., 2008) on total and partial columns. The error due to the air broadening coefficient uncertainty is negligible for total columns but can be as large as $4 \%$ when partial columns are concerned (Barret et al., 2003; Schneider et al., 2008). Other sources of systematic errors, such as the temperature or the instrumental line-shape (if not correctly determined), should also be considered in the upper layers (García et al., 2012).

The ozone trends in Vigouroux et al. (2008) were calculated with a bootstrap re-sampling method, applied to the daily mean partial columns of the ozone time series. This work was extended up to 2009 in the WMO 2010 ozone assessment report (WMO, 2011) for five European stations $\left(28^{\circ} \mathrm{N}\right.$ to $\left.79^{\circ} \mathrm{N}\right)$. A current update up to 2012 is ongoing, involving additional stations, including stations in the Southern Hemisphere. The spectroscopic database has been changed to HITRAN 2008 (Rothman et al., 2009), and an additional effort of homogenization has been made in contrast to the work described in Vigouroux et al. (2008); all stations are using a priori information from the model WACCM.

The length of the FTIR ozone time series varies by station (see Fig. 1 for the geographical distribution of the stations); the longest time series available starts in 1995, and the shortest in 2002 (Fig. 2; Table 1c). In the coming years, more recently established observatory stations (e. g. Reunion Island: measurements started in 2009; Toronto: regular data containing the $1000-1005 \mathrm{~cm}^{-1}$ range started in 2010) or stations that have not yet reprocessed their retrievals using the optimized common strategy (e.g.: Eureka, Bremen) could be included in ozone trends studies.

The FTIR data not yet available on the NDACC database (see Table 1d for the URL) can be acquired by direct contact with the responsible principal investigator. There are currently 17 active long-term NDACC FTIR sites. An additional long-term site (Kitt Peak, AZ, USA $\left(31.9^{\circ} \mathrm{N}, 111.6^{\circ} \mathrm{W}\right)$ ) has data from 1978-2005, but operations have unfortunately ceased.

\subsection{Microwave}

The NDACC microwave ozone profiling instruments measure the spectra of emission lines produced by thermally excited, purely rotational ozone transitions at millimeter wavelengths. All are based on the same principles but differ in technical details. All use a sensitive heterodyne downconverter (receiver) that produces a replica of the spectrum it receives from the sky at a much lower so-called intermediate frequency where it can be processed by a filter bank or digital FFT spectrometer. In all systems, the spectral intensity scale is established by substituting the thermal radiation from two black body sources for the radiation from the sky at the receiver input. One source is at ambient temperature, the second is typically chilled using liquid nitrogen. The ozone altitude distribution is retrieved from the details of the pressure broadened line shape, typically using various implementations of the optimal estimation method of Rodgers (1976). The attenuation of the ozone signal in the troposphere is determined by measuring the tropospheric thermal emission and relating the tropospheric opacity to its emission using a radiative transfer model. Stratospheric aerosols do not affect microwave measurements because the wavelength is large compared to the aerosol particle size. The altitude range is between about 20 and $55-72 \mathrm{~km}$, depending on the instrument (Table 1a, b). The fundamental native measurement units are mixing ratio vs. pressure. The instruments operate continuously, and profile retrievals are obtained in weather ranging from clear to some overcast conditions. Temporal resolution can be hourly or less, so diurnal variations of ozone in the stratosphere and mesosphere can be observed.

The instruments at Lauder (New Zealand), Bern and Payerne (Switzerland), and Mauna Loa/Hawaii (USA) have operated essentially continuously from 1992, 1994, 2000, and 1995 to the present respectively. Ny Ålesund (Norway) has been making measurements since 1994, with some extended breaks. These are NDACC Primary Instruments listed in http://www.iapmw.unibe.ch/research/collaboration/ ndsc-microwave/instruments/index_spe.html. Other instruments, also listed on the above site, have operated over periods of months to a decade (Table 1c). Instrument and measurement details for Lauder and Mauna Loa were published in Parrish et al. (1992), for Payerne in Maillard-Barras et al. (2009) and Hocke et al. (2007), for Bern in Studer et al. (2013), for Ny Ålesund in Palm et al. (2010). Data from these instruments are archived on the NDACC webpage (see Table 1d for URL).

Theoretical investigations of microwave ozone measurement errors and vertical resolution have been reported by Connor et al. (1995) and Palm et al. (2010). The former is applicable to the Lauder and Mauna Loa measurements, the latter to the Ny Alesund measurements. As the vertical resolution of microwave measurements can vary by amounts approaching a factor of two from one instrument to another, it is important to download the averaging kernels along with the data and consider them in the analysis when comparing microwave measurement results. Discussions of the averaging kernels and vertical resolution are found in 
Connor et al. (1995) and Caliesi (2000). The values shown in Fig. 3a are an ensemble average. Because instrument calibration is based on temperature it can theoretically be kept stable over long periods of time. In practice, a more important issue is that the details of the spectral line shape must be measured with a precision that is technically challenging to achieve. The types of spectral errors most commonly encountered tend to propagate into profile errors in the lower to middle stratosphere. Despite these challenges, the profiles of the Mauna Loa and Lauder instruments were found to agree with others to within $<5 \%$ from $\approx 22$ to $65 \mathrm{~km}$ during formal blind intercomparison campaigns involving several types of instruments (McDermid et al., 1998a, b; McPeters et al., 1999). Differences between the Bern (Studer et al., 2013) instrument and others mostly fall within $\approx 7 \%$, as do those at Payerne up to $\approx 50 \mathrm{~km}$. Relative drifts between the Lauder and MLO measurements and those made with lidar, ozonesonde, SAGE II, and HALOE were typically $<0.5 \% \mathrm{yr}^{-1}$ from 22 to $60 \mathrm{~km}$ over the period from the mid-1990s to the mid-2000s (Boyd et al., 2007). While no decadal-scale drift tests have been reported for the other stations, Steinbrecht et al. (2009) found that the Bern measurements were very consistent with others over the period from 1994 to 2008 .

\section{Satellite-based measurement systems}

In the following paragraphs several satellite-based systems measuring ozone profiles are described. Systems are grouped according to measurement technique. The solar occultation technique provides spectral measurements with a very high signal-to-noise ratio allowing the detection of species with low concentrations without the need for averaging measurements. This self-calibrating method is less susceptible to changes in instrument performance over the mission lifetime because of the reference exo-atmospheric measurements used in the retrieval. Stellar occultation measurements are relative by definition and therefore they are less sensitive to instrumental degradation. Due to the multitude of stars, global coverage is obtained. Since stars are point sources, the pointing information is excellent (uncertainty $<30 \mathrm{~m}$ ) and the vertical resolution very good, about $2 \mathrm{~km}$ around the ozone maximum and below. The limb viewing technique offers high sensitivity to a number of trace gases with vertical resolution between 1 and $3 \mathrm{~km}$ (depending on instrument and wavelength) and provides day and night retrievals (only day retrievals for limb-scatter instruments), with dense sampling along the sub-orbital tracks and hundreds to a few thousands of profiles per day. Self-calibration is typically provided by reference views to (stable) cold space and onboard blackbody targets, whereas limb-scatter instruments either use the extraterrestrial solar spectra or limb measurements at upper tangent height(s) for normalization. Nadir viewing instruments provide full global coverage of the Earth on a daily basis, with $6 \mathrm{~km}$ vertical resolution for the stratospheric ozone profile, and between tens and hundreds of thousands of profiles per day. Detailed information on ozone data collected by limb sounders, their vertical and spatial resolution, and comparisons between individual ozone climatologies for longterm changes is provided in a study by Tegtmeier et al. (2013) about the Stratospheric Processes and their Role in Climate (SPARC) initiative on trace gas and aerosol climatologies.

Temporal coverage of each measurement system is shown in Fig. 2. Average spatial coverage for the solar-occultation instruments is shown in Fig. 4 since this is very distinct for each of the systems. Spatial coverage for the stellaroccultation, limb and nadir systems described in the following sections is shown in detail in Toohey et al. (2013), and is therefore not explicitly repeated here. Figure $3 b-d$ show in detail the vertical resolution of each of the satellite measurement systems that are described below.

\subsection{Solar-occultation instruments}

\subsubsection{SAGE}

All of the Stratospheric Aerosol and Gas Experiment (SAGE) instruments (SAGE I on the Applications Explorer Mission-B (AEM-B), SAGE II on the Earth Radiation Budget Satellite (ERBS) and SAGE III on the Meteor-3M spacecraft), used solar occultation to take spectral transmission measurements along a slant path through the atmosphere. SAGE III added lunar occultation measurements. The SAGE instruments scanned a small field of view across the solar disk every $2 \mathrm{~s}$. The wavelength-dependent atmospheric transmission is determined by taking the ratio of a measurement looking through the atmosphere to one taken when the sun or moon is above the atmosphere as seen from the spacecraft. The systematic uncertainty of the transmission is independent of instrument characteristics as long as the instrument is stable over the brief few minutes spanned by each occultation event. Ozone is inferred from spectral measurements near $600 \mathrm{~nm}$, at the peak of the Chappuis band and nearby channels are used primarily to characterize the spectral aerosol extinction. The small field of view and high signal-to-noise ratio enabled by looking at such bright sources enables the retrieval of the ozone profile at $1 \mathrm{~km}$ vertical resolution with low random uncertainty $(\approx 1 \%)$ from just below the tropopause to well above the stratopause (Table 1a, b).

SAGE I made measurements over a 33 month period, starting in February 1979 (Fig. 2). SAGE II made measurements for 21 years starting in October 1984 (Table 1c) covering the time when ozone depletion was at its peak as well as during the transition to lower chlorine loading in response to the Montreal Protocol. SAGE III made measurements from December 2001 to December 2005; it provided complementary high-latitude coverage (Fig. 4).

The solar occultation technique produces a very stable long-term data set. The ratio between scans across the solar 


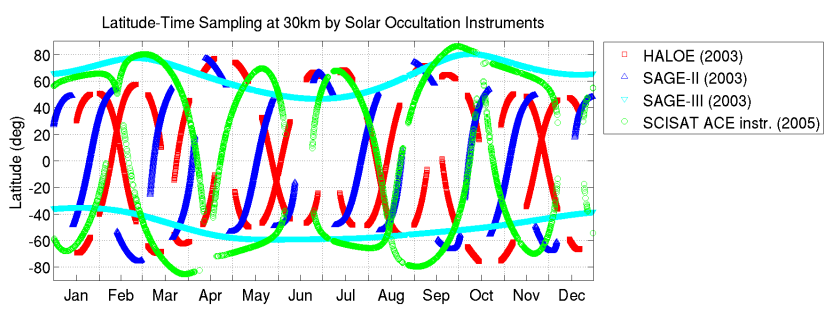

Figure 4. Latitudinal coverage for the solar-occultation instruments (example years: 2003 and 2005). SAGE I is similar to SAGE II (blue triangles), POAM and ILAS instruments are similar to SAGE III (turquoise triangles).

disk above the atmosphere and scans through the atmosphere to determine the spectral extinction vs. altitude are calculated. The instrumental radiometric properties divide out in this ratio. Scanning across, rather than staring at, the sun provides accurate knowledge of the altitude registration of each measurement.

The most recent version of the SAGE data is version 7 . This is the first version that will unify the algorithm, ancillary data and spectroscopy across all three SAGE missions (Damadeo et al., 2013). Data are archived at the Atmospheric Science Data Center, NASA Langley Research Center in Hampton, Virginia (see Table 1d for URL).

\subsubsection{HALOE}

The Halogen Occultation Experiment (HALOE) was launched aboard the Upper Atmosphere Research Satellite (UARS) in 1991 and operated successfully for fourteen years until November 2005. HALOE made global observations verifying the effects of chlorine compounds on the chemical loss of ozone in the upper stratosphere. In addition to $\mathrm{HCl}$ and ozone, HALOE provided profile measurements of $\mathrm{H}_{2} \mathrm{O}$, $\mathrm{CH}_{4}, \mathrm{NO}, \mathrm{NO}_{2}, \mathrm{HF}$, temperature and aerosol extinction using the technique of solar occultation. Its measurements of $\mathrm{HF}, \mathrm{HCl}, \mathrm{CH}_{4}$, and $\mathrm{NO}$ were obtained using gas filter correlation radiometry. HALOE ozone transmission profiles were measured by the more traditional method of broadband filter radiometry (Russell III et al., 1993), using a broadband channel from 9.2 to 10.4 micrometers. Overall measurement uncertainties range from $9-25 \%$ in the lower stratosphere and from $9-20 \%$ in the upper stratosphere and mesosphere.

The HALOE retrieval algorithm employed a top-down, onion-peeling approach and iterated the calculated tangentlayer transmissions to achieve a match with the measured transmissions from each of its channels. Measured transmissions are calibrated according to their solar look values at top of scan. The one exception was the method for obtaining the temperature profile, which began with the assignment of the co-located National Center for Environmental Prediction (NCEP) temperature and pressure (or $T(p)$ value) at $31.5 \mathrm{~km}$ to the HALOE-measured $\mathrm{CO}_{2}$ channel transmission profile at that same level. Then, a first-guess $T(p)$ profile was iterated and proceeded upward by matching the calculated transmission value in each tangent layer with that observed in the HALOE $\mathrm{CO}_{2}$ channel centered at $2.8 \mu \mathrm{m}$. The measured transmission profiles for all the species, including ozone, were then registered vs. the pressure profiles obtained in this way, prior to final retrievals of the species volume mixing ratio profiles (Table 1a-c). The HALOE Level 2 profiles can be downloaded from the NASA Goddard Earth Sciences Data \& Information Services Center (GES DISC) or the HALOE webpage (see Table 1d for the URLs).

\subsubsection{ILAS and ILAS-II}

The Improved Limb Atmospheric Spectrometer (ILAS) was a satellite-borne solar-occultation sensor on board the Japanese Advanced Earth Observing Satellite (ADEOS) (Sasano, 2002). ILAS consisted of an infrared spectrometer that covers the wavelength region from about 6 to $12 \mu \mathrm{m}$ with a detector array of 44 elements and a visible spectrometer from 753 to $784 \mu \mathrm{m}$ with a detector array of 1024 elements. ADEOS was successfully launched in a sun-synchronous orbit on 17 August 1996. After a 3 month initial checkout period, continuous operation of ILAS started on 30 October, lasting until 29 June 1997 when a failure in the satellite's solar battery system occurred (Fig. 2). For a period of about 8 months, ILAS made solar-occultation measurements at 57$71^{\circ} \mathrm{N}$ and $64-88^{\circ} \mathrm{S}$, and collecting $\approx 6700$ profiles of $\mathrm{O}_{3}$, $\mathrm{HNO}_{3}, \mathrm{NO}_{2}, \mathrm{~N}_{2} \mathrm{O}, \mathrm{CH}_{4}, \mathrm{H}_{2} \mathrm{O}$ and aerosol extinction coefficients at $780 \mathrm{~nm}$.

ILAS-II was a satellite-borne solar-occultation sensor on board the satellite ADEOS-II (Nakajima, 2006). ILAS-II consisted of four spectrometers: an infrared spectrometer (between $6.21 \mu \mathrm{m}$ to $11.76 \mu \mathrm{m}$ ); a mid-infrared spectrometer (between $3.0 \mu \mathrm{m}$ and $5.7 \mu \mathrm{m}$ ); a high-resolution infrared spectrometer (between $12.78 \mu \mathrm{m}$ and $12.85 \mu \mathrm{m}$ ); and a visible spectrometer (between $753 \mathrm{~nm}$ and $784 \mathrm{~nm}$ ). ADEOS-II was successfully launched on 14 December 2002, also in a sunsynchronous orbit. After a 3 month initial checkout period, continuous operation of ILAS-II started on 2 April 2003, lasting until 24 October 2003 when the satellite's solar battery system malfunctioned (Fig. 2, Table 1c). For a period of about 7 months, ILAS-II made solar-occultation measurements at $57-71^{\circ} \mathrm{N}$ and $64-88^{\circ} \mathrm{S}$, and gathered $\approx 5700$ profiles of $\mathrm{O}_{3}, \mathrm{HNO}_{3}, \mathrm{NO}_{2}, \mathrm{~N}_{2} \mathrm{O}, \mathrm{CH}_{4}, \mathrm{H}_{2} \mathrm{O}, \mathrm{ClONO}_{2}$, $\mathrm{N}_{2} \mathrm{O}_{5}$, CFC-11, CFC-12 and aerosol extinction coefficients at $780 \mathrm{~nm}$.

Ozone and other minor gas vertical profiles were retrieved by applying both the onion-peeling method and the nonlinear least-squares fitting method. Version 5.20 ILAS and version 1.4 ILAS-II ozone profiles were validated by comparing with various data sources (Sugita et al., 2002, 2006). These validations showed that ILAS ozone data agreed with other data sets within $\pm 10 \%$ with a few exceptions between 11 and $64 \mathrm{~km}$ (Table 1a, b). ILAS-II ozone data agreed with 
other data sets within $\pm 10 \%$ at altitudes between 11 and $40 \mathrm{~km}$ for the Northern Hemisphere. Above $41 \mathrm{~km}$, a negative bias between the NH ILAS-II ozone data and the other data increased, reaching $30 \%$ at $61-65 \mathrm{~km}$. Southern Hemisphere ILAS-II ozone data agreed with other data sets within $\pm 10 \%$ at altitudes between 11 and $60 \mathrm{~km}$. Since the solaroccultation technique is used with both ILAS and ILAS-II, the instruments are self-calibrated by measuring $100 \%$ and $0 \%$ intensity of the sun each time before and after the atmospheric measurement. ILAS ozone data are archived at the ILAS and ILAS-II webpages (see Table 1d for URLs).

\subsubsection{POAM II and POAM III}

The Polar Ozone and Aerosol Measurement II (POAM II) instrument was developed by the Naval Research Laboratory (NRL) to measure the vertical distribution of atmospheric ozone, $\mathrm{H}_{2} \mathrm{O}, \mathrm{NO}_{2}$, aerosol extinction and temperature using with the solar-occultation technique. POAM II measured solar extinction in nine narrow band channels, covering the spectral range from approximately 350 to $1060 \mathrm{~nm}$. POAM II was launched aboard the French SPOT-3 satellite on 26 September 1993 into a sun-synchronous polar orbit. The POAM II mission was ended by the failure of the SPOT3 satellite in November of 1996 (Fig. 2).

The POAM III instrument was a satellite-based ninechannel, visible-near-infrared photometer for making measurements of ozone, aerosol extinction, $\mathrm{H}_{2} \mathrm{O}$ and $\mathrm{NO}_{2}$ in the polar stratosphere using the solar occultation technique (Lucke et al., 1999). The POAM III instrument was developed by NRL and measured solar extinction in nine narrow band channels, covering the spectral range from approximately 350 to $1020 \mathrm{~nm}$. POAM III was carried by the French SPOT-4 spacecraft, which launched on an Ariane-4 rocket in March 1998. The POAM III instrument failed on 5 December 2005.

POAM made 14-15 measurements per day in each hemisphere around a circle of latitude. In the Northern Hemisphere the measurement latitude ranged from $55^{\circ} \mathrm{N}$ to $73^{\circ} \mathrm{N}$, and in the Southern Hemisphere, $63^{\circ} \mathrm{S}$ to $88^{\circ} \mathrm{S}$. The POAM III retrieval version 4 includes the following profile data: ozone concentration $(5-60 \mathrm{~km}), \mathrm{NO}_{2}$ concentration (20$40 \mathrm{~km})$, aerosol extinction at 6 wavelengths $(5-25 \mathrm{~km}), \mathrm{H}_{2} \mathrm{O}$ (5-45 km) and UK Met Office temperature, pressure, and potential vorticity $(0-60 \mathrm{~km})$, all with a $\approx 1 \mathrm{~km}$ vertical resolution. POAM II has a slightly smaller altitude range for the retrieved profiles than POAM III (Table 1a, b). The estimate for random error on the retrieved concentrations is approximately $3-5 \%$ above $20 \mathrm{~km}$ and increasing at lower altitudes. For a complete error analysis see Lumpe et al. (2002). As solar occultation instruments, both POAM systems are largely self-calibrating. No drift of degradation of the POAM III ozone retrievals has been observed.

The most recent version of the POAM retrieved profiles is version 4 (pdf document on the POAM ftp archive, see
Table 1d for URL), which differs only very little from version 3 (Lumpe et al., 2002). Data is available either through the NASA Langley Atmospheric Science Data Center or through the Naval Research Laboratory (see Table 1d for URLs).

\subsubsection{ACE-MAESTRO}

The atmospheric chemistry experiment (ACE) Measurement of Aerosol Extinction in the Stratosphere and Troposphere (MAESTRO) occultation instrument (McElroy et al., 2007; Nowlan et al., 2007), on board the Canadian SCISAT satellite, is a dual, diode-array spectrometer measuring in the UVVIS-NIR spectral range with a nominal wavelength range of $285-1015 \mathrm{~nm}$ (525 and $1010 \mathrm{~nm}$ for its primary ozone measurement mode in solar occultation). SCISAT was designed to measure the composition of the Earth's atmosphere from space, with particular emphasis on the middle atmosphere ozone distribution, and related trace gases in the Arctic. The satellite was launched on 12 August 2003 and designed for a 2 year mission and is currently still in operation (Fig. 2). It is in a $74^{\circ}$ inclined circular orbit at an altitude of $650 \mathrm{~km}$.

MAESTRO makes measurements in the solar occultation mode and shares a common sun tracker and optical viewing direction with the atmospheric chemistry experimentFourier transform spectrometer instrument on the same satellite. Therefore, they observe almost exactly the same slant column of air, albeit with different fields of view, and with only a slight difference resulting from differential refractive effects. MAESTRO has a relatively small $\left(0.02^{\circ}\right)$ optical resolution which provides a resolution of $\approx 1 \mathrm{~km}$ in altitude (Table 1b).

The primary purpose in adding MAESTRO to the satellite payload was to obtain wavelength-dependent, aerosol extinction information. However, in order to remove the effects of gaseous absorbers, a spectral fitting analysis is done which produces ozone, $\mathrm{NO}_{2}$ and water vapor slant column amounts. Vertical profiles of these species in volume mixing ratio are also produced, covering the altitude range of 5-35 km (Table 1a). Overall uncertainty on the retrieved profiles is $\approx 10 \%$, with smaller uncertainties $(\approx 3 \%)$ in the midto upper stratosphere (Dupuy et al., 2009; Kar et al., 2007).

Because MAESTRO is measuring in occultation mode, a reference spectrum is collected before or after each occultation. Therefore, the optical depths calculated are almost independent of instrument sensitivity. The UV half of MAESTRO has lost sensitivity steadily throughout the mission, with the loss of sensitivity migrating from shorter to longer wavelengths to the point where the instrument has produced no useful data for the last five years. However, the visiblenear-IR spectrophotometer has shown very little change in sensitivity. Based on the behavior of the two instruments in the overlap region of the spectrum it is likely that the loss of sensitivity is due to attenuation taking place outside the instrument. 
MAESTRO data can be obtained from the ACE Science Team at the University of Waterloo, Canada (see Table 1d for URL).

\subsubsection{ACE-FTS}

The atmospheric chemistry experiment-Fourier transform spectrometer (ACE-FTS), on board the SCISAT satellite, is a solar occultation instrument measuring in the mid-infrared spectral region (Bernath, 2006). SCISAT began routine measurements on 21 February 2004 and is still currently in operation (Fig. 2).

ACE-FTS is a high-resolution $\left(0.02 \mathrm{~cm}^{-1}\right)$ FTS that measures the full spectral range between 750 and $4400 \mathrm{~cm}^{-1}$ (Bernath et al., 2005). Each day ACE-FTS measures approximately 15 sunrise and 15 sunset occultations and achieves nearly complete global latitude coverage over a period of three months (e.g., one "season"; Table 1c). These midinfrared spectral measurements extend from the cloud tops to $150 \mathrm{~km}$ and ozone is retrieved up to $95 \mathrm{~km}$ (Table 1a). The vertical spacing between each $2 \mathrm{~s}$ ACE-FTS measurement varies between 1.5 and $6 \mathrm{~km}$ depending on the satellite's orbit geometry. The vertical sampling is $3-4 \mathrm{~km}$ based on the field of view of the instrument (Table 1b).

Constituent profiles are retrieved from the ACE-FTS transmission spectra as volume mixing ratios (VMRs) using an unconstrained non-linear least-squares global fitting approach (Boone et al., 2005). Initially, $\mathrm{CO}_{2}$ transitions are used to determine the pressure and temperature as a function of altitude between 12 and $120 \mathrm{~km}$. Below $12 \mathrm{~km}$, meteorological results from the Canadian Meteorological Centre (CMC) operational weather analysis and forecast system are used (note that in version 3.5 of the ACE-FTS retrievals, the CMC pressure and temperature results are used below $15 \mathrm{~km}$, Boone et al., 2013). The resulting temperature and pressure profiles are the basis for retrieving VMR profiles of ozone and over 30 trace gas species. For the ozone retrieval, spectral features between 984 and $1190 \mathrm{~cm}^{-1}$ are used.

The spectroscopic parameters on which the calculations are based are derived from the HIgh-resolution TRANsmission (HITRAN) molecular absorption database 2004 line list (Rothman et al., 2005). The version 2.2 ozone updated (herein v2.2) data set was validated extensively by Dupuy et al. (2009). In comparisons with ozonesondes and satellite limb sounding instruments, a small positive bias of +1 to $+8 \%$ ( $+5 \%$ on average) was found between 16 and $44 \mathrm{~km}$. At altitudes above $45 \mathrm{~km}$, larger differences of up to $+40 \%$ ( $+20 \%$ on average) are found for the v2.2 ozone profiles. The current version of the ACE-FTS data set is version 3.5 (Boone et al., 2013). Waymark, et al. (2013) have evaluated the differences between the well-validated v2.2 and new v3.5 profiles and found that there is a reduction of $\approx 5 \%$ at altitudes above $35 \mathrm{~km}$ in v3.5 compared to v2.2. There is no detailed error budget available for the ACE-FTS ozone product at present. However, there is an associated fitting uncertainty provided for each measurement.

The ACE-FTS instrument is self-calibrating. A series of reference exo-atmospheric spectra ("high sun" measurements) are collected during each orbit and are used with the atmospheric measurements to calculate the transmittance spectra that are then used in the retrieval process. Data are made available by the ACE team on request or via webpage of the ACE Science Team at the University of Waterloo, Canada (see Table 1d for more detail).

\subsection{Stellar occultation instruments}

\subsubsection{GOMOS}

The Global Ozone Monitoring by Occultation of Stars (GOMOS) instrument is one of the three atmospheric instruments on-board the European Space Agency's Environmental Satellite (Envisat) satellite. The satellite was launched in March 2002 into a polar sun-synchronous orbit with a descending node at 22:00 LT GOMOS measurements ceased in April 2012 when contact with Envisat was lost (Fig. 2). About 410000 nighttime ozone profiles were measured by GOMOS during its 10 year period of operation.

The GOMOS spectrometer covers the wavelength range from ultraviolet, visible and near infrared (UV-VIS-NIR). It uses the stellar occultation technique for observing trace gas and aerosol profiles from the upper troposphere to the mesosphere (Bertaux et al., 2010). Approximately 160 stars are bright enough for atmospheric profiling, providing global coverage from pole to pole. The altitude range is typically from the top of the clouds to $100 \mathrm{~km}$ (Table 1a). Geophysical validations have shown that the nighttime measurements of ozone are accurate with a $\pm 2 \%$ bias in the stratosphere between 20-40 km (e.g. Meijer et al., 2004; van Gijsel et al., 2010). The sampling resolution of GOMOS is $0.5-1.7 \mathrm{~km}$ depending on the geometry of the occultation (Table 1b). Due to refraction the sampling resolution improves below $40 \mathrm{~km}$. The stars are point sources, which ensures very good knowledge of the measurement position $(<30 \mathrm{~m})$.

The retrieval of ozone and other trace gases using stellar occultation method is relatively straightforward (Kyrölä et al., 2010). The present retrieval assumes known Rayleigh extinction, which is estimated using the European Centre for Medium-Range Weather Forecasts (ECMWF) and MSIS90 models for neutral density profiles. Only a minimal amount of a priori information on ozone is needed and it is included in the retrieval by using Tikhonov regularization method assuming smoothness of the ozone profiles. The vertical resolution of the ozone profiles is thus lower than the actual sampling resolution: $2 \mathrm{~km}$ in the stratosphere and $3 \mathrm{~km}$ in the mesosphere. Ozone is retrieved together with aerosols, $\mathrm{NO}_{2}$, and $\mathrm{NO}_{3}$ using wide wavelength band $250-675 \mathrm{~nm}$. The stellar characteristics (temperature and brightness) are linked to signal-to-noise ratio resulting in a varying random 
uncertainty of the data depending on the stars used. The random uncertainty of ozone measurements in the stratosphere ranges from $0.5-4 \%$, except in the lowermost stratosphere where values are about $10 \%$, and $2-10 \%$ in the mesosphere. The largest systematic error contribution is due to uncertainties in aerosol modeling and is about $20 \%$ below $20 \mathrm{~km}$, $1-5 \%$ at $20-25 \mathrm{~km}$ and negligible above $25 \mathrm{~km}$ (Tamminen et al., 2010).

As an occultation instrument GOMOS is, in principle, less sensitive to instrument degradation. However, careful evaluation of possible drifts is needed since the signal to noise ratio is low with dim stars and the increasing amount of dark charge is known to cause problems despite the selfcalibrating measurement principle. These problems are minimized by careful screening of the data for dim and cool stars.

In addition to the nighttime occultation measurements discussed above, GOMOS has daytime occultation measurements (Table 1c). Presently GOMOS daytime occultations are of poor quality (e.g. van Gijsel et al., 2010). Daytime ozone profiles can, however, be derived from GOMOS measurements of scattered solar light (Tukiainen et al., 2011). These data are processed by the Finnish Meteorological Institute (FMI) and ozone profiles are available from the ESA SPIN project. All occultation measurements are available via the ESA EARTHNET webpage (see Table 1d for more detail).

\subsection{Limb emission instruments}

\subsubsection{LIMS}

The Limb Infrared Monitor of the Stratosphere (LIMS), an infrared, limb-emission instrument, operated on Nimbus 7 following its launch in late October 1978 through late May 1979, at which time its solid cryogen coolant was depleted (Fig. 2). The quality of the original LIMS Version 5 data set is described in Gille and Russell III (1984) and references therein. The LIMS retrieval algorithm uses a top-down onion-peeling approach and iterates to achieve a match of the calculated and measured limb radiances for its wide and narrow $\mathrm{CO} 2$ radiometer channels in the 15-micrometer region. A constant $\mathrm{CO}_{2}$ volume mixing ratio profile of $325 \mathrm{ppmv}$ is assumed for the radiance calculations in the upper stratosphere, where the forward models for the wide and narrow $\mathrm{CO}_{2}$ channels are aligned and iterated. Radiance profiles for the LIMS species channels are registered against the pressure profiles that are obtained in this manner.

In order for the LIMS data set to be more compatible with those from instruments of the UARS, Envisat, and the EOS satellite programs of more recent decades, LIMS profiles were retrieved anew using updated spectral line parameters for $\mathrm{CO}_{2}$ and other species, including ozone, from the 1992 or 1996 HITRAN line lists (Remsberg et al., 2004). LIMS ozone profiles were obtained from infrared limb radiance measurements at 9 to 10 micrometers. The resultant
LIMS Version 6 Level 2 profiles of temperature, species and height are tabulated at 18 levels per decade of pressure or at a spacing of $0.88 \mathrm{~km}$ (Table 1a). They have an effective vertical resolution of $3.7 \mathrm{~km}$, in order to account properly for the effects of the instrument on the observed radiances and of the retrieved temperatures on the retrieved ozone profiles (Table 1b). The Version 6 data set was processed in 2002 and the Level 2 and 3 products are archived at NASA Goddard (GES DISC; see Table 1d for URL). A more detailed description of the LIMS V6 ozone and its quality is provided in Remsberg et al. (2007). Overall uncertainties for LIMS ozone range from $20-30 \%$ in the lower stratosphere, to approximately $12 \%$ in the mid- to upper stratosphere.

Each measured, up/down horizon radiance scan pair included a view of its warm, internal blackbody, followed by a calibration measurement of cold space. Characteristics of the blackbody remained stable throughout the 7.25 months of the LIMS mission.

Most recently, Remsberg et al. (2013) reported on the assimilation of the LIMS V6 ozone into the GEOS-5 model of NASA's Modern-Era Retrospective Analysis for Research and Applications (MERRA) system. They reported a problem with the LIMS ozone data at pressures higher than about $50 \mathrm{hPa}$ (volume mixing ratios less than $0.1 \mathrm{ppmv}$ at low latitudes) and, therefore, recommend that these data be screened out prior to using the LIMS data set for detailed scientific studies of lower stratospheric ozone.

\subsubsection{UARS MLS}

The Upper Atmosphere Research Satellite (UARS) Microwave Limb Sounder (MLS) was one of ten instruments on the NASA UARS platform, launched on 12 September 1991 (Reber et al., 1993, Fig. 2). UARS-MLS (a predecessor to Aura MLS) pioneered microwave limb sounding of the Earth's stratosphere and mesosphere from space (see Barath et al., 1993; Waters, 1993). UARS-MLS measured microwave emission near $205 \mathrm{GHz}$ for its primary stratospheric ozone retrievals. The UARS orbit was inclined at $57^{\circ}$ and MLS data coverage was from $34^{\circ}$ on one side of the equator to $80^{\circ}$ on the other side, switching sides after each satellite yaw maneuver (which occurred roughly every 36 days). The measurements thus cover all local solar times during each "yaw period". Profiles were spaced $\approx 3-4^{\circ}$ along the orbit track and the average daily sampling in longitude is $\approx 12^{\circ}$; there are about 1350 profiles per day (Table $1 \mathrm{c}$ ). The frequency of UARS-MLS operational days generally decreased from about $100 \%$ in late 1991 through 1993, to about $50 \%$ in late 1994 and down to as low as a few tens of days per year from 1995 onward.

The UARS MLS data are considered most robust for time series analyses through mid-June 1997, after which cessation of $63 \mathrm{GHz}$ observations (to save spacecraft power) resulted in the loss of retrieved temperatures. The retrieval algorithms were based on optimal estimation, as for Aura MLS, 
but without two-dimensional retrieval capabilities to account for horizontal volume mixing ratio gradients. Version 5 was the most recent public release of UARS MLS $\mathrm{O}_{3}$ data (see Livesey et al., 2003) and the work by Froidevaux et al. (1996) on an earlier data version for more details and validation results).

UARS MLS ozone profiles are recommended from 100 to $0.22 \mathrm{hPa}$ and are retrieved on the same vertical grid as for Aura MLS v2.2 $\mathrm{O}_{3}$; the vertical resolution is $3.5-5 \mathrm{~km}$ in the stratosphere and 5-8 km in the mesosphere (Table 1a, b). Estimated random errors are $0.2-0.3$ ppmv and typical systematic error estimates $(2 \sigma)$ are $\approx 6 \%$, degrading to $15 \%$ (or more) near $68-100 \mathrm{hPa}$, where some high biases vs. correlative data were noted. The official public distribution location for UARS MLS data is at the NASA GES-DISC Mirador website (see Table 1d for URL).

\subsubsection{Aura MLS}

NASA's Earth Observing System (EOS) Microwave Limb Sounder (MLS) instrument was launched on the Aura satellite on 15 July 2004 (Fig. 2). This improved sounder (and successor to UARS MLS) measures a variety of atmospheric species (and temperature); $\mathrm{O}_{3}$ retrievals are provided from the upper troposphere to the mesosphere. Aura MLS performs limb scans ahead of the Aura satellite, which is in a sun-synchronous, near-polar orbit. Aura MLS measures ozone microwave emission for its primary (standard) product near $240 \mathrm{GHz}$. Retrieved profiles occur at the same latitude every orbit and are separated by $\approx 170 \mathrm{~km}$ along the sub-orbital track. This yields nearly 3500 profiles every day (day and night) from $82^{\circ} \mathrm{S}$ to $82^{\circ} \mathrm{N}$ (Table 1c). Waters et al. (2006) describe the instrument and its measurements.

The Aura MLS retrievals are obtained via optimal estimation (Rodgers, 1976, 2000). Gauss-Newton iteration is used, with a second-order Tikhonov constraint (Tikhonov, 1963). This constraint is applied to the profile second derivatives (vertically and horizontally). Specific retrieval aspects include adaptation to a two-dimensional system, using the line-of-sight measurements from several scans to derive multi-profile information (Livesey and Read, 2000). The Level 2 data include screening flags regarding instrument/retrieval status, quality of fit and retrieval convergence (see Froidevaux et al., 2008). Retrieval details are provided by Livesey et al. (2006) and references therein.

Version $2.2 \mathrm{O}_{3}$ is retrieved on a pressure grid with 6 levels per decade up to $0.1 \mathrm{hPa}$ (and coarser vertical resolution above this); v3.3 data are provided on a finer grid and down to $261 \mathrm{hPa}$, but are not recommended overall over v2.2 because of larger vertical oscillations in the upper troposphere and lower stratosphere (UTLS) at low latitudes (Table 1a). Aura MLS v2.2 single profiles are recommended for scientific use in the $215 \mathrm{hPa}$ to $0.02 \mathrm{hPa}$ range; the vertical resolution is $\approx 3 \mathrm{~km}$ (or slightly less) in the stratosphere, degrading to 4 $6 \mathrm{~km}$ for pressures of $0.1 \mathrm{hPa}$ or less (Table 1b). Estimated random errors are 0.1 to $0.3 \mathrm{ppmv}(\approx 2-15 \%)$ and systematic error estimates $(2 \sigma)$ are $5-10 \%$ for most of the stratosphere and lower mesosphere (for more details and validation, see Froidevaux et al., 2008, and references therein). The official public distribution location for Aura MLS data is at the NASA GES-DISC Mirador website (see Table 1d for URL).

\subsubsection{MIPAS}

The Michelson Interferometer for Passive Atmospheric Sounding (MIPAS) is a limb emission, Fourier transform spectrometer (Fischer et al., 2008). Looking horizontally through the atmosphere at various elevation angles, it measured high-resolution, infrared emission spectra of atmospheric constituents, thus providing altitude-resolved information on these constituents. MIPAS was one of the atmospheric chemistry instruments on the ESA's Envisat research satellite, which was launched into its sun-synchronous polar orbit on 1 March 2002. In March 2004, problems with the interferometer slide occurred and operation was interrupted; however, on 27 January 2005 operation in the nominal mode was resumed with reduced spectral but improved spatial resolution (optimized resolution measurements). MIPAS provided data until 8 April 2012 when contact to the satellite was lost (Fig. 2).

There exist multiple MIPAS level-2 retrievals. One version was generated with the research processor developed and operated by the Institute of Meteorology and Climate Research (IMK), KIT, Karlsruhe, Germany, in cooperation with the Instituto de Astrofisica de Andalucía (IAA), CSIC, Granada, Spain (von Clarmann et al., 2003, 2009). The retrieval was performed on a fixed altitude grid usually finer than the tangent altitude spacing, and was regularized by a Tikhonov first order approach that leads to smoothing of the profiles without bias towards an a priori. IMK high-spectral-resolution ozone data (2002-2004) were validated by Steck et al. (2007) and the first validation of the reduced spectral resolution data was published by Stiller et al. (2012).

Frequent gain and offset calibration by means of deep space and blackbody measurements minimize drifts of MIPAS measurements. There is a higher order effect due to slowly decreasing detector non-linearity that is overestimated towards the end of the MIPAS measurement period. This explains a predominantly negative drift of MIPAS-IMK ozone vs. MLS-Aura ozone, which can reach -0.2 ppmv decade $^{-1}$ around $40 \mathrm{~km}$ (Eckert et al., 2014).

Another MIPAS processor is run by ESA (Ridolfi et al., 2000; Raspollini et al., 2006, 2013b). It is based on the algorithm ORM (optimized retrieval model) developed by an European Consortium led by IFAC-CNR (Istituto di Fisica Applicata "Nello Carrara", part of the Consiglio Nazionale delle Ricerche). This processor was specifically designed for operating in near-real time, and hence for working automatically in different atmospheric conditions, and uses the minimum amount of a priori information that may introduce a bias 
in the profiles. To this purpose, it uses the LevenbergMarquardt regularization inside the iterations and an a posteriori Tikhonov regularization with a self-adapting constraint that ensure that minimum constraints are used and the best vertical resolution obtainable from the measurements is achieved in all atmospheric conditions. ESA high-spectralresolution ozone data (2002-2004) were validated by Cortesi et al. (2007).

A third MIPAS retrieval algorithm was developed at Oxford University (Moore and Remedios, 2010) and is based on the optimal estimation approach (Rodgers, 2000). A fourth retrieval algorithm, GMTR, has been developed as a joint effort of the University of Bologna and ISAC-CNR (Carlotti et al., 2006). The algorithm performs simultaneous retrievals of pressure, temperature, water and ozone analyzing all the measurements acquired during a full Envisat orbit using a two-dimensional approach. The GMTR algorithm has been used to analyze the full MIPAS mission and the results are stored into the MIPAS2D database (Dinelli et al., 2010, 2012). All these algorithms use the same level-1b data, which is provided by ESA, but differ in some assumptions for the forward model and for the spectral intervals used in the analysis (Laeng et al., 2014; Raspollini et al., 2013a).

Recently the full validation of the ozone products of the four cited algorithms (Laeng et al., 2014), an assessment of the long-term stability, and an assessment of the 10 year trend of the IMK/IAA data product (Eckert et al., 2014) have been completed. Overall uncertainties on the ozone profiles range from $35-40 \%$ at $10 \mathrm{~km}$ to $8-11 \%$ at around $30 \mathrm{~km}$. Vertical resolution for optimized resolution phase (years 2005-2012) ranges from $2-2.4 \mathrm{~km}$ at $10 \mathrm{~km}$ and $3.2-3.6 \mathrm{~km}$ at $30 \mathrm{~km}$ to $5 \mathrm{~km}$ at $70 \mathrm{~km}$. Vertical resolution for full resolution phase (years 2002-2004) ranges from $4 \mathrm{~km}$ around $10 \mathrm{~km}$ to $5 \mathrm{~km}$ around $30 \mathrm{~km}$, to $8 \mathrm{~km}$ at $70 \mathrm{~km}$ (Table $1 \mathrm{~b}$ ). In order to avoid artifacts in trend estimation from two data subsets of different characteristics resulting from the different measurement modes before and after 2004, a dedicated scheme has been developed that is immune to biases between data subsets (von Clarmann et al., 2010). The IMK/IAA MIPAS data are accessible at the IMK webpage (see Table 1d for URL). The ESA MIPAS data are accessible at the ESA webpage (see Table 1d for URL). The MIPAS2D database is undergoing a validation process (Casadio et al., 2013), but the data is accessible through the ISAC-CNR web site (see Table 1d for URL). The MIPAS data retrieved by the Oxford group is not publicly available at this point.

\subsubsection{Odin-SMR}

The Odin satellite orbit is approximately $600 \mathrm{~km}$ and sunsynchronous. The orbit has precessed over the eleven years since Odin was launched but the local times of the measurements have remained relatively stable (equator crossing times between 06:00-07:00 and 18:00-19:00). The Odin sun-synchronous orbit leads to daytime observations in the summer hemisphere and nighttime observations in the winter hemisphere.

The Sub-Millimeter Radiometer (SMR) on board the Odin satellite, launched in 2001, makes limb measurements of thermal emission lines of ozone in several different spectral bands. The $501.8 \mathrm{GHz}$ version 2.1 level-2 product provides stratospheric ozone data in the $\approx 12-60 \mathrm{~km}$ range (above $17-$ $18 \mathrm{~km}$ at mid-latitudes) with $2.5-3.5 \mathrm{~km}$ vertical resolution and single-profile random uncertainty of about $20 \%$ (Jones et al., 2007; Jégou et al., 2008, Table 1a, b). The systematic error is estimated to be smaller than $0.75 \mathrm{ppmv}$ (Urban et al., 2005, 2006).

Measurements in this observation mode were carried out on every 3rd day until April 2007 and on every other day thereafter (Fig. 2). The thermal emission technique allows ozone to be measured during day and night and global fields between $\approx 83^{\circ} \mathrm{S}$ and $\approx 83^{\circ} \mathrm{N}$ are produced during typically 14-15 orbits per observation day based on up to 65 limbscans per orbit.

The calibration for SMR is done with a standard hot-cold radiance calibration scheme, based on the internal hot load (viewed at the end of each scan, i.e. every 90 s) and cold sky (viewed each tangent-view, i.e. every $0.85 \mathrm{~s}$ ). This leads to an excellent long-term stability of the measurements. There are no known signs of instrument degradation so far.

Individual ozone profiles of the $501.8 \mathrm{GHz}$ band are quite noisy since they are derived from a relatively weak line, but averages agree well with correlative measurements (Jones et al., 2009). Other SMR ozone products such as from the strong ozone line in the $544.6 \mathrm{GHz}$ band (version 2.0) are less noisy but have larger (known) biases. Data are available from the Odin-SMR webpage (see Table 1d for URL).

\subsubsection{SMILES}

The Superconducting Submillimeter-Wave Limb-Emission Sounder (SMILES) was developed and operated under the cooperation of the Japan Aerospace Exploration Agency (JAXA) and the National Institute of Information and Communications Technology (NICT) (Kikuchi et al., 2010). SMILES conducted its atmospheric observations from 12 October 2009 to 21 April 2010 (Fig. 2) on the Japanese Experiment Module (JEM) aboard the International Space Station (ISS). SMILES used three observation bands in the frequency regions of $624.32-626.32 \mathrm{GHz}$ and 649.12 $650.32 \mathrm{GHz}$. This instrument measured about 1600 profiles per day (both daytime and nighttime) within the latitude range of $38^{\circ} \mathrm{S}-65^{\circ} \mathrm{N}$. Owing to the non-sun-synchronous orbit of the ISS, measurements of the atmosphere are taken at different local times. This data set provides unprecedented opportunities to study diurnal ozone variations throughout the stratosphere (Imai et al., 2013; Sakazaki et al., 2013; Kasai et al., 2013; Kreyling et al., 2013).

The SMILES mission has two products for ozone. One is the JAXA product (Imai et al., 2013) and the other is the 
NICT product (Kasai et al., 2013). Version 3.0 (118-12-0602) of $\mathrm{O}_{3}$ profiles in SMILES JAXA product are retrieved based on the combination of Optimal Estimation method (Rodgers, 2000) with Tikhonov Regularization method (L2 constraint). Degradation of the instrument is corrected by an engineering process that uses some parameters obtained by on-orbit calibrations to obtain brightness temperature spectra from raw data (Ochiai et al., 2013). The SMILES ozone product provides ozone concentration as a value of volume mixing ratio. The nominal retrieved altitude range is from 8 to $120 \mathrm{~km}$, and the typical "useful altitude range" is from 16 to $95 \mathrm{~km}$ (Table 1a). The retrieval vertical grid step is $2.5 \mathrm{~km}$ throughout the retrieval altitude range (Table $1 \mathrm{~b}$ ). The information on the convergence status of iteration in retrieval process, the validity of the observation altitude range, and the FOV interference onboard the ISS, are represented as the "screening flags" and these flags are stored in the "status field" of each HDF file.

The NICT products of ozone is called SMILES NICT Level-2 (L2) version 2.1.5 product, which used the version 007 calibrated Level-1b (L1b) spectra. The detail of the evaluation of the $\mathrm{L} 1 \mathrm{~b}$ spectrum, retrieval procedure including the theoretical error analysis, and comparison/evaluation of the ozone vertical profile was shown in Kasai et al. (2013).

The public SMILES L2 and L3 (SMILES climatology) data are available from the Data ARchives and Transmission System (DARTS) in the Institute of Space and Astronautical Science (ISAS) of JAXA and from the NICT SMILES page (see Table 1d for URLs).

\subsection{Limb scattering instruments}

\subsubsection{SCIAMACHY}

The Scanning Imaging Absorption spectroMeter for Atmospheric CHartographY (SCIAMACHY) was a payload on Envisat launched in March 2002 (Burrows et al., 1995; Bovensmann et al., 1999, 2011). Due to the failure of communication to the Envisat platform, SCIAMACHY measurements ended in April 2012. SCIAMACHY is one of the newgeneration space-borne instruments capable of performing spectrally resolved measurements in several different modes: alternate nadir and limb observations of the solar radiation scattered in the atmosphere or reflected by the Earth's surface as well as observations of the light transmitted through the atmosphere during solar or lunar occultation. SCIAMACHY was a passive imaging spectrometer comprising eight spectral channels covering a wide spectral range from 214 to $2386 \mathrm{~nm}$. For the limb-scatter ozone profile retrieval selected wavelengths in the Hartley (ultraviolet) and Chappuis (visible) ozone bands are used (Sonkaew et al., 2009).

In the limb-scatter geometry, SCIAMACHY observed the atmosphere tangentially to the Earth's surface starting at $\approx 3 \mathrm{~km}$ below the horizon, i.e., when the Earth's surface is still within the field of view of the instrument, and then scanned vertically up to the top of the neutral atmosphere (about $100 \mathrm{~km}$ tangent height; Table 1a). The useful vertical range for ozone retrieval is about 10 to $60 \mathrm{~km}$ altitude and the vertical resolution of the retrieved ozone profiles is about $4 \mathrm{~km}$ (Table $1 \mathrm{~b}$ ). In the nominal mode about 100 measurements per orbit with 14 orbits per day were performed. Global coverage of the sunlit part of the earth was achieved in 6 days (Table 1c).

Similar to other limb-scattering instruments, pointing uncertainty is a major error source (von Savigny et al., 2005). The systematic uncertainty of the pointing for the whole limb scan is estimated to be about $200 \mathrm{~m}$. The relative pointing error between different tangent heights is negligible. Above $20 \mathrm{~km}$ measurements have uncertainties up to $15 \%$ (for a single profile), with a possible $8 \%$ systematic error. Extensive validation of the SCIAMACHY limb-scatter ozone profiles by comparisons with other satellites has been reported for an earlier retrieval version in Mieruch et al. (2012). A detailed error budget is provided in Rahpoe et al. (2013) and ozone trends during the last decade are reported in Gebhardt et al. (2014). Instrument calibration effects are largely removed by using ratios of the limb spectra at different tangent heights. SCIAMACHY version 2.5 data are available from the webpage of the Institute of Environmental Physics, University of Bremen, Germany (see Table 1d for URL).

An alternative retrieval of ozone profiles from SCIAMACHY limb observations is provided by the European Space Agency/DLR (Doicu et al., 2007).

\subsubsection{Odin-OSIRIS}

The Canadian-built, Optical Spectrograph and InfraRed Imaging System (OSIRIS) (Llewellyn et al., 2004) has been in routine operation on the Swedish spacecraft Odin (Murtagh et al., 2002) since the fall of 2001 (Fig. 2). OSIRIS measures vertically resolved profiles of spectrally dispersed limb scattered sunlight from $280 \mathrm{~nm}$ to $800 \mathrm{~nm}$ with approximately $1 \mathrm{~nm}$ resolution. Typically the Odin spacecraft rotates to scan the OSIRIS single line of sight through a tangent altitude range that extends from $10 \mathrm{~km}$ to $60 \mathrm{~km}$ (Table 1a). In the sunlit part of the orbit, a single vertical ozone profile is retrieved from a single Odin scan that typically takes $90 \mathrm{~s}$. This results in as many as 60 scans per orbit (Table 1c). The Odin scan speed along with the OSIRIS imaging rate and instantaneous field of view combine to give an approximately $1.5 \mathrm{~km}$ sampling resolution in the UTLS and $2 \mathrm{~km}$ at higher altitudes (Table 1b).

The retrieval scheme used to infer vertical ozone profiles from limb-scattered sunlight was developed at the University of Saskatchewan (Degenstein et al., 2009) and involves an adapted Multiplicative Algebraic Reconstruction Technique and the SASKTRAN (Bourassa et al., 2007) radiative transfer model. The vertical ozone profile within the SASKTRAN model is relaxed in a multiplicative fashion until the 
model and measurements agree to within a certain tolerance. This method is extremely stable, and because the OSIRIS noise values are very low, the retrieved data quality is very good. Overall uncertainties range from $5 \%$ between $25 \mathrm{~km}$ and $50 \mathrm{~km}, 15 \%$ below $20 \mathrm{~km}$ and $7 \%$ between $50 \mathrm{~km}$ and $55 \mathrm{~km}$.

Studies have shown that OSIRIS ozone compares well with coincident SAGE II ozone profiles with biases less than $3 \%$ from 18 to $50 \mathrm{~km}$ (Degenstein et al., 2009). OSIRIS retrievals are self-calibrating as the radiance data is normalized against both higher altitudes and non-absorbing wavelengths. These normalizations stabilize the retrieval to the majority of known factors; the exception being upwelling radiation from the ground and lower troposphere. Data are available from the Odin-OSIRIS webpage (see Table 1d for URL).

\subsection{Nadir-viewing instruments}

\subsubsection{SBUV}

The Solar Backscatter Ultraviolet (SBUV) instruments are nadir-viewing instruments that infer total column ozone and the ozone vertical profile by measuring sunlight scattered from the atmosphere in the middle ultraviolet. The instruments use Ebert-Fastie type double monochromators and measure at twelve discrete wavelengths from $252-340 \mathrm{~nm}$. The ratios of the backscattered radiance to direct solar irradiance are used to infer ozone concentration as a function of altitude. Optimal estimation techniques are used to invert the measurements and estimate ozone amounts as a function of pressure (Table 1a). The vertical resolution of SBUV is $6 \mathrm{~km}$ in the upper stratosphere $(\approx 3 \mathrm{hPa})$ and gets progressively worse at higher and lower altitudes, particularly in the tropics (Table 1b). Figure 9 in Bhartia et al. (2013) provides more details.

The SBUV record is the longest available for satellitebased profile ozone measurements from a single instrument type (McPeters et al., 2013). The record began with the launch of Nimbus-4 BUV in 1970. An improved version, SBUV, was launched in October 1978 on the Nimbus-7 satellite. In 1984 the first of seven SBUV/2 instruments was launched on the NOAA-9 satellite, with subsequent launches on the NOAA 11, 14, 16, 17, 18, and 19 satellites (Fig. 2).

The instruments are flown in sun-synchronous polar orbits to obtain global coverage. Since the measurements rely on backscattered sunlight, data are taken only on the daylight side of each orbit and no data are taken during polar winter. The NOAA polar orbiting satellites were not exactly sunsynchronous and consequently drifted from near-noon orbits with NOAAs 9-14 drifting the most. NOAA-11 for example, drifted from an initial 13:30 equator-crossing time to a 17:00 orbit in six years, returning as a morning orbit for the later part of the data record. Starting with NOAA-16, the orbital drift was partially mitigated, providing $\approx 5$ years of data before significant drift began. As the orbit drifts the solar zenith angle at which the measurements are made increases and latitude coverage decreases, which can be a problem for trend determination (Table 1c).

The most recent retrieval algorithm is Version 8.6 (Bhartia et al., 2013). Significant changes from Version 8 include new ozone (McPeters and Labow, 2012) and cloud climatologies (Joiner and Vasilkov, 2006), a change in ozone cross sections to Brion, Daumont, and Malicet, and updated instrument calibration (DeLand et al., 2012). The absolute calibrations of the individual instruments are adjusted at the radiance level to improve the consistency over the multi-instrument period. This is accomplished using coincident measurements during periods of overlap referred to as the "no local time" correction. Local solar time coincidence is required as well as spatial coincidence to account for real diurnal variations in ozone (DeLand et al., 2012). The instruments have been cross-calibrated during two time periods. The calibration of NOAA-17 SBUV/2 is used as the standard for NOAA-14, NOAA-16, and NOAA-18, while the NOAA-11 base calibration is used as the reference for the Nimbus- 7 and NOAA 9 absolute calibrations. No instrument overlaps Nimbus-4 BUV; its absolute calibration is based on comparisons with ground-based instruments and has not changed in Version 8.6.

The primary data product for time-series analysis is the monthly zonal-mean data, available at the NASA Goddard DISC webpage (see Table 1d for URL). Validation of SBUV monthly zonal-mean profiles (Kramarova et al., 2013b) shows that the mean biases and standard deviations are mostly within $5 \%$ in the stratosphere between 25 and $1 \mathrm{hPa}$. The SBUV vertical resolution decreases in the lower stratosphere and troposphere, and as a result the SBUV smoothing error, defined as the component of vertical ozone variability that the observation system cannot measure, increases from $<1 \%$ in the middle stratosphere up to $10-15 \%$ in the lower stratosphere and troposphere. Combining layers in the troposphere/lower stratosphere and above $1 \mathrm{hPa}$ is recommended to limit smoothing errors, as described in Kramarova et al. (2013a).

In order to make the SBUV measurements accessible for trend analysis, it is necessary to combine the data from the different NOAA satellites. Two versions of a "merged" data set are available (NASA Goddard, S. Frith, personal communication, 2013; NOAA CPC, J. Wild, personal communication, 2013). Both are described in more detail in the second and third $\mathrm{SI}^{2} \mathrm{~N}$ overview papers (Lambert et al., 2014; Harris et al., 2014).

\subsubsection{GOME/GOME-2}

The Global Ozone Monitoring Experiment (GOME) is a nadir-scanning ultraviolet and visible (UV-VIS) spectrometer. Its launch on board the European Remote Sensing 2 satellite in April 1995 started a new era of measuring Earth-reflected solar radiation with relatively high spectral 
resolution for UV-VIS wavelengths (Fig. 2). SCIAMACHY, GOME-2 and OMI followed the GOME heritage. The UVVIS spectrum between $270 \mathrm{~nm}$ and $340 \mathrm{~nm}$ is used for deriving global, height-resolved information on the ozone distribution in the atmosphere (Munro et al., 1998). As for SBUV, Optimal Estimation techniques (Rodgers, 2000) are used for the retrievals. GOME ozone profiles were extensively analyzed by Meijer et al. (2006) and when the OMI measurements became available these were validated by Kroon et al. (2011).

A common feature of nadir UV-VIS ozone profiles is their limited vertical resolution, estimated typically at $7-15 \mathrm{~km}$, with a considerable amount of vertical smoothing (Table 1b). Smoothing of the retrieved ozone profile is described by the averaging kernel, which is part of the retrieval results. Uncertainty of the retrieved ozone profile is determined by measurement error, a priori error and by smoothing error (about $30 \%$ in the troposphere, and $\approx 10 \%$ in the stratosphere). The ozone profile retrieval depends on the absolute calibration of the instruments and therefore it is sensitive to degradation effects. An offline degradation correction is needed in case of degradation of the instrument.

Within the climate change initiative (CCI) program of ESA, a new algorithm has been developed to generate highquality data for nadir ozone profiles from GOME, SCIAMACHY and GOME-2. Data are available from the EUMETSAT archive, and it is planned to make it accessible via CCI web portal (see Table 1d for URLs). Furthermore, GOME-2 profiles are retrieved on an operational basis by KNMI within the framework of EUMETSAT's Ozone and Atmospheric Chemistry Monitoring SAF (O3MSAF) (e.g. Mijling et al., 2010; van Peet et al., 2009) that can be accessed via the Eumetcast dissemination (see Table 1d for URL).

\subsubsection{OMI}

The Ozone Monitoring Instrument (OMI) is an imaging nadir viewing UV-VIS spectrometer on board of the Aura satellite mission (Levelt et al., 2006a, b). Due to the application of two-dimensional detectors OMI combines daily global coverage with a relative high spatial resolution of $13 \mathrm{~km} \times 24 \mathrm{~km}$ at nadir for wavelengths from 308 to $500 \mathrm{~nm}$ and $13 \mathrm{~km} \times 48 \mathrm{~km}$ for wavelengths below $308 \mathrm{~nm}$. The OMI science data record currently extents from October 2004 to present (Fig. 2). The OMI instrument is extremely stable radiometrically, with only a few percent of degradation even in the shortest ultraviolet channels, making it a unique data set for ozone monitoring. Since the beginning of 2009 part the OMI swath is affected by the so-called row anomaly (http://www.knmi.nl/omi/research/ product/rowanomaly-background.php).
The OMI instrument will be succeeded by the TROPOMI instrument on board of the Sentinel-5 Precursor satellite, planned for launch late 2015 (Veefkind et al., 2012). TROPOMI uses the same observation technique as OMI, and includes several improvements, including the signal-to-noise ratio, the spatial resolution and additional spectral bands. TROPOMI will have a separate spectral band from 270 to $320 \mathrm{~nm}$, which is expected to lead to improved ozone profile retrievals.

The ozone profile retrieval for OMI is based on the optimal estimation method (Rodgers, 2000). As discussed above in the GOME/GOME-2 section (Sect. 3.5.2), the vertical information is limited, especially in the UTLS and the troposphere (Table 1a-c). The OMI ozone profile data are available at the NASA Goddard DISC (see Table 1d for URL). The validation status of this product is described in Kroon et al. (2011) based on comparisons with ozonesondes and several satellite data products. Since the beginning of 2009 part of the OMI swath is affected by the so-called row anomaly (http://www.knmi.nl/omi/research/ product/rowanomaly-background.php). This has several effects on the data quality and some of these depend on the position in the orbit. Currently the effect of the row anomaly on the ozone profile quality in the Northern Hemisphere has not yet been fully quantified. In the future, further improvements to the OMI ozone profile product are planned using a new version of the retrieval algorithm including accurate flagging of the row anomaly. In addition to the product available at the NASA DISC, there is also a research product (Liu et al., 2010), with a strong focus on the retrieval of tropospheric ozone information.

\subsubsection{IASI}

The Infrared Atmospheric Sounding Interferometer (IASI) instrument is a nadir-viewing, Fourier transform spectrometer. It was first launched on board the sun-synchronous polar orbiting MetOp-A satellite on 19 October 2006 (Fig. 2). A second instrument was launched on 17 September 2012 on board Metop-B and, together with the forthcoming Metop-C, will ensure products continuity for at least 15 years.

IASI scans across track in 30 successive steps (four pixels are acquired simultaneously) either side of nadir, with a total swath of around $2000 \mathrm{~km}$ (Table 1c). This allows for global coverage twice a day. Each field of view has a typical footprint size of $12 \mathrm{~km}$ at nadir. IASI measures spectra in the thermal infrared between 645 and $2760 \mathrm{~cm}^{-1}$ at a spectral sampling of $0.25 \mathrm{~cm}^{-1}\left(0.5 \mathrm{~cm}^{-1}\right.$ resolution after apodization). The 8461 channels are distributed in 3 bands, which, due to their spectral coverage, allow for the retrieval of surface and cloud properties, temperature and humidity profiles as well as ozone and a number of other atmospheric constituents (e.g. $\mathrm{CO}, \mathrm{CH}_{4}, \mathrm{NH}_{3}, \mathrm{SO}_{2}$ ). The ozone profiles are retrieved in near-real time, using the FORLI-O3 (Fast Optimal Retrievals on Layers for IASI) software (Hurtmans 
et al., 2012), and will be available as part of the IASI Level 2 product processing facility (August et al., 2012, Table 1a-c). Validation was performed using ground-based (Antón et al., 2011; Dufour et al., 2012), aircraft (Parrington et al., 2012; Pommier et al., 2012), balloon (Gazeaux et al., 2013) and other satellite data (Scannell et al., 2012).

IASI is auto-calibrated, with high radiometric accuracy. Retrieval methods for profile measurements use standard Optimal Estimation Method (OEM) or regularization techniques. Overall uncertainties in the ozone profiles range from about $20-30 \%$ in the altitude range $0-6 \mathrm{~km}$, and are about $10-20 \%$ in the stratosphere and upper troposphere. At the moment, IASI ozone data are available from the IASI team on request. Data should be available via Eumetcast in 2014 (see Table 1d for more detail).

\subsection{Additional instruments}

Beyond the instruments/missions described in detail above, several other satellite instruments also provide ozone data. These will only be mentioned briefly in the following paragraphs since these instruments were either not used in any $\mathrm{SI}^{2} \mathrm{~N}$ activity (e.g. included in merged data sets, or updated and improved retrievals) or have their main focus on tropospheric rather than stratospheric measurements. However, for the sake of completeness we include them here.

The TES (Tropospheric Emission Sounder) instrument on board of Aura is a nadir-looking high-resolution infraredimaging Fourier transform spectrometer observing in nadir, which provides profiles of ozone and many other trace species in the troposphere and lowermost stratosphere. TES provides about 1000 observations a day, with a nadir footprint of $5 \mathrm{~km} \times 8 \mathrm{~km}$. The sensitivity of the measurements is highest in the mid-troposphere. The data record has been thoroughly validated (Worden et al., 2007).

The HIRDLS (High-Resolution Dynamics Limb Sounder) instrument is a 21 channel (from 6.12 to 17.76 microns) limb scanning infrared radiometer measuring emission from the Earth's limb onboard Aura. These measurements are inverted to yield global distributions of temperature, clouds, aerosols, and concentrations of ozone and other trace gases at high vertical and horizontal resolution from the upper troposphere into the mesosphere. After launch, activation of the HIRDLS instrument revealed that the optical path was blocked so that $20 \%$ of the aperture could view the Earth's atmosphere. Nevertheless, measurements at high vertical resolution could be made at one scan angle. Geographically the data extend from $63^{\circ} \mathrm{S}$ to $80^{\circ} \mathrm{N}$ with $1^{\circ}$ spacing, and cover the period from 29 January 2005 to 17 March 2008, with very few gaps. The estimated total accuracy is $1-10 \%$, varying with altitude and latitude, and 10 to $>50 \%$ in the tropical UTLS (Nardi et al., 2008).

The Sounding of the Atmosphere using Broadband Emission Radiometry (SABER) instrument provides volume mixing ratio profiles of ozone from $15-100 \mathrm{~km}$ retrieved from mid-infrared limb emission measurements (Russell III et al., 1999). The validation of the v1.07 ozone profiles in the middle and upper atmosphere $(\approx 15-70 \mathrm{~km})$ are described in Rong et al. (2009).

\section{Summary}

This paper describes long-term ozone profile data derived from five of the most common ground-based systems and 19 satellite-based instruments. The physical principles of measurements, specifics of data retrievals and uncertainties of measurements have been described in more detail in various publications and reports with relevant references given in this paper. Therefore, the goal of this paper is to provide an overview of well-established ozone records, while also offering updated information on recently reprocessed and newly available data sources. The summary includes links to data archives, lists uncertainties of measurements and retrievals, provides spatial and temporal characteristics of the data sets described above and indicates the latest released data version (see Table 1d, the numbers given are indicative or typical values). This overview does not represent a complete list of all available ozone profile measurements, but aims to provide the community with information about the latest improvements and recalculations of the most commonly used ozone profile time series data that are most relevant in the context of trend analysis, bundled in one place for easy access and comparison.

Although according to Figs. 2 and 3 (also Fig. 1 in Toohey et al., 2013), it appears that the ozone profile measurements are available globally for the entire 1960-2000 period, one needs to keep in mind that there are regions of the globe and times when data coverage is sparse. A small number of quasi-continuous ground-based measurements by the Umkehr method began in the early 1960s and only a few ozonesonde locations provide continuous records going back to the late 1960s; there is thus limited Northern Hemisphere mid-latitude information about ozone changes in the 1960s and throughout most of the 1970s and virtually no information for other parts of the globe. At the beginning of the 1990 high-quality ozone profile measurement at NDACC sites started providing reliable long-term information at selected locations. However, ground-based measurement stations are not uniformly distributed around the globe. The coverage of the ozone variability at high latitudes and, to some extent, in the tropics, were improved by various polar research projects and with the SHADOZ network. Nevertheless, there are still large regions with low-measurement frequency and sparse coverage.

More complete information for the global analysis of ozone changes only became available with the launch of the first satellite instruments. A BUV instrument operated for a limited period in the early 1970s with quasi-continuous satellite monitoring starting in the late 1970s. The period 
between the end of the SAGE I measurements and the beginning of the SAGE II measurements (see Fig. 2) has proven to be one of the most challenging obstacles for reliable, highly vertically resolved, global ozone trend detection, especially with the altitude registration problems reported for SAGE I measurements (Wang et al., 1996). SBUV measurements are available during this time, however, their coarse vertical resolution compared to the SAGE measurements severely limits their utility in tying the two SAGE records together, especially in the lower stratosphere. It is evident that the largest ozone decreases in the extra tropics occurred during the 1980s and, therefore, the beginning of this decade is often used as the starting point for trend analyses. However, correctly anchoring trends in this period is complicated and represents a challenge for long-term trend analysis (McPeters et al., 1994; Randel et al., 1999; Cunnold et al., 2000; Wang et al., 2002; Terao and Logan, 2007).

Another period of sparse global measurements resulted from the eruption of Mt. Pinatubo in June 1991. The increased aerosol loading in the stratosphere resulted in retrieval problems for several satellite instruments (and some ground-based instruments) measuring at that time (SAGE II, HALOE, SBUV), resulting in recommendations by some instrument science teams that some ozone data for multiple months after the Pinatubo eruption be discarded (Yu and She, 1995; Cunnold et al., 1996; Bhartia et al., 2013). This reduces the available lower stratospheric ozone measurements during that period to primarily ground-based instruments (ozonesondes).

One goal of the $\mathrm{SI}^{2} \mathrm{~N}$ Initiative is to make the measurement community aware of the increased demand for high-quality and consistent data sets with well-defined uncertainty estimates to fulfill requirements for advanced statistical methods used to detect small changes in stratospheric ozone variability. It is clear that ODS reductions in response to the Montreal Protocol has led to a reversal of the negative column ozone trends in the extra tropics (e.g. Ziemke and Chandra, 2012); however, the documentation of the beneficial effect on ozone profile changes is still challenging (in particular, in an atmosphere where greenhouse gas increases may also be playing a role). As stated earlier, this is the first of three initiative overview papers and provides a summary of available ozone profile measurements. The second overview paper (Lambert et al., 2014) focuses on comparison and validation of the different data sets and the different retrievals for the various instruments that are introduced here. A quantitative understanding of the offsets and drifts among data sets and their limitations is essential when merging them for timeseries analyses. The third overview paper (Harris et al., 2014) focuses on describing and characterizing data sets that have been derived from a combination of different data sources (multiple satellite instruments). Several of these combined data sets are compared to each other and a detailed evaluation of them is given.
Together, the three overview papers provide the scientific community with a source of information about the latest activities of ozone profile measurement groups, with the intention of providing needed background information and guidance for future ozone profile trend analysis. However, at this point it is also important to point out that there remains a significant need for high-quality stratospheric ozone measurements. Even with the reduction of ODSs in the stratosphere following the Montreal Protocol and its Amendments and Adjustments an exact attribution of stratospheric ozone recovery is not possible due to changes associated with increasing greenhouse gas concentrations. Only with highly stable and accurate profile ozone measurements will it be possible to separate and correctly attribute future ozone changes and verify ozone recovery.

Acknowledgements. We would like to thank the different agencies that support missions with instruments that measure stratospheric ozone profiles (ESA, NASA, NOAA, JAXA, NICT, CSA, SNSB, CNES, NSO, NIES, MOE, Eumetsat). We also would like to thank the different national and international agencies that fund groundbased measurements and several databases where ground-based measurements are stored and made accessible (NDACC, WOUDC, SHADOZ). The atmospheric chemistry experiment (ACE) is a Canadian-led mission mainly supported by the Canadian Space Agency and the Natural Sciences and Engineering Research Council of Canada. SCIAMACHY is jointly funded by Germany, the Netherlands and Belgium. Work at the Jet Propulsion Laboratory was performed under contract with the National Aeronautics and Space Administration. The IMK data analysis was co-funded by DLR under contract 50 EE 0901. Publication of this article was funded by the University of Colorado Boulder Libraries Open Access Fund and the SPARC-Office.

Edited by: R. Eckman

\section{References}

Antón, M., Loyola, D., Clerbaux, C., López, M., Vilaplana, J. M. Bañón, M., Hadji-Lazaro, J., Valks, P., Hao, N., Zimmer, W., Coheur, P. F., Hurtmans, D., and Alados-Arboledas, L.: Validation of the Metop-A total ozone data from GOME-2 and IASI using reference ground-based measurements at the Iberian Peninsula, Remote Sens. Environ., 115, 1380-1386, 2011.

Attmannspacher, A. and Dütsch, H. U.: International ozone sonde intercomparison at the Observatory Hohenpeissenberg, Ber. Dtsch. Wetterdienstes, 120, 1-85, 1970.

Attmannspacher, A. and Dütsch, H. U.: Second international ozone sonde intercomparison at the Observatory Hohenpeissenberg, Ber. Dtsch. Wetterdienstes, 157, 1-64, 1980.

August, T., Klaes, D., Schlüssel, P., Hultberg, T., Crapeau, M., Arriaga, A., O'Carroll, A., Coppens, D., Munro, R., and Calbet, X.: IASI on Metop-A: operational level 2 retrievals after five years in orbit, J. Quant. Spectrosc. Ra., 113, 1340-1371, doi:10.1016/j.jqsrt.2012.02.028, 2012.

Barath, F. T., Chavez, M. C., Cofield, R. E., Flower, D. A., Frerking, M. A., Gram, M. B., Harris, W. M., Holden, J. R., Jarnot, R. F., Kloezeman, W. G., Klose, G. J., Lau, G. K., 
Loo, M. S., Maddison, B. J., Mattauch, R. J., McKinney, R. P., Peckham, G. E., Pickett, H. M., Siebes, G., Soltis, F. S., Suttie, R. A., Tarsala, J. A., Waters, J. W., and Wilson, W. J.: The upper atmosphere research satellite microwave limb sounder instrument, J. Geophys. Res., 98, 10751-10762, doi:10.1029/93JD00798, 1993.

Baron, P., Urban, J., Sagawa, H., Möller, J., Murtagh, D. P., Mendrok, J., Dupuy, E., Sato, T. O., Ochiai, S., Suzuki, K., Manabe, T., Nishibori, T., Kikuchi, K., Sato, R., Takayanagi, M., Murayama, Y., Shiotani, M., and Kasai, Y.: The Level 2 research product algorithms for the Superconducting Submillimeter-Wave Limb-Emission Sounder (SMILES), Atmos. Meas. Tech., 4, 2105-2124, doi:10.5194/amt-4-2105-2011, 2011.

Barret, B., De Mazière, M., and Demoulin, P.: Retrieval and characterization of ozone profiles from solar infrared spectra at the Jungfraujoch, J. Geophys. Res., 107, 4788, doi:10.1029/2001JD001298, 2002.

Barret, B., De Mazière, M., and Demoulin, P.: Correction to "Retrieval and characterization of ozone profiles from solar infrared spectra at the Jungfraujoch", J. Geophys. Res., 108, 4372, doi:10.1029/2003JD003809, 2003.

Bernath, P.: Atmospheric Chemistry Experiment (ACE): analytical chemistry from orbit, TRAC-Trend, Anal. Chem., 25, 647-654, 2006.

Bernath, P. F., McElroy, C. T., Abrams, M. C., Boone, C. D., Butler, M., Camy-Peyret, C., Carleer, M., Clerbaux, C., Coheur, P.F., Colin, R., DeCola, P., DeMaziere, M., Drummond, J. R., Dufour, D., Evans, W. F. J., Fast, H., Fussen, D., Gilbert, K., Jennings, D. E., Llewellyn, E. J., Lowe, R. P., Mahieu, E., McConnell, J. C., McHugh, M., McLeod, S. D., Michaud, R., Midwinter, C., Nassar, R., Nichitiu, F., Nowlan, C., Rinsland, C. P., Rochon, Y. J., Rowlands, N., Semeniuk, K., Simon, P., Skelton, R., Sloan, J. J., Soucy, M.-A., Strong, K., Tremblay, P., Turnbull, D., Walker, K. A., Walkty, I., Wardle, D. A., Wehrle, V., Zander, R., and Zou, J.: Atmospheric Chemistry Experiment (ACE): mission overview, Geophys. Res. Lett., 32, L15S01, doi:10.1029/2005GL022386, 2005.

Bertaux, J. L., Kyrölä, E., Fussen, D., Hauchecorne, A., Dalaudier, F., Sofieva, V., Tamminen, J., Vanhellemont, F., Fanton d'Andon, O., Barrot, G., Mangin, A., Blanot, L., Lebrun, J. C., Pérot, K., Fehr, T., Saavedra, L., Leppelmeier, G. W., and Fraisse, R.: Global ozone monitoring by occultation of stars: an overview of GOMOS measurements on ENVISAT, Atmos. Chem. Phys., 10, 12091-12148, doi:10.5194/acp-1012091-2010, 2010.

Bhartia, P. K., McPeters, R. D., Flynn, L. E., Taylor, S., Kramarova, N. A., Frith, S., Fisher, B., and DeLand, M.: Solar Backscatter UV (SBUV) total ozone and profile algorithm, Atmos. Meas. Tech., 6, 2533-2548, doi:10.5194/amt-6-2533-2013, 2013.

Bodeker, G. E., Hassler, B., Young, P. J., and Portmann, R. W.: A vertically resolved, global, gap-free ozone database for assessing or constraining global climate model simulations, Earth Syst. Sci. Data, 5, 31-43, doi:10.5194/essd-5-31-2013, 2013.

Boone, C. D., Nassar, R., Walker, K. A., Rochon, Y., McLeod, S. D., Rinsland, C. P., and Bernath, P. F.: Retrievals for the Atmospheric Chemistry Experiment Fourier-Transform Spectrometer, Appl. Optics, 44, 7218-7231, 2005.
Boone, C. D., Walker, K. A., and Bernath, P. F.: Version 3 retrievals for the Atmospheric Chemistry Experiment Fourier Transform Spectrometer (ACE-FTS), in: The Atmospheric Chemistry Experiment ACE at 10: a Solar Occultation Anthology, A. Deepak Publishing, Hampton, Virginia, USA, 2013.

Bourassa, A. E., Degenstein, D. A., Llewellyn, E. J., and SASKTRAN: A spherical geometry radiative transfer code for efficient estimation of limb scattered sunlight, J. Quant. Spectrosc. Ra., 109, 52-73, doi:10.1016/j.jqsrt.2007.07.007, 2007.

Bovensmann, H., Burrows, J. P., Buchwitz, M., Frerick, J., Noel, S., Rozanov, V. V., Chance, K. V., and Goede, A. H. P.: SCIAMACHY - mission objectives and measurement modes, J. Atmos. Sci., 56, 127-150, 1999.

Bovensmann, H., Aben, I., van Roozendael, M., Kühl, S., Gottwald, M., von Savigny, C., Buchwitz, M., Richter, A., Frankenberg, C., Stammes, P., de Graaf, M., Wittrock, F., Sinnhuber, M., Sinnhuber, B.-M., Schönhardt, A., Beirle, S., Gloudemans, A., Schrijver, H., Bracher, A., Rozanov, A. V., Weber, M., and Burrows, J. P.: SCHIAMACHY's view of the changing earth's environment, in: SCIAMACHY - Exploring the Changing Atmosphere, Springer, Dordrecht, 175-216, doi:10.1007/978-90-481-9896-2_10, 2011.

Boyd, I. S., Parrish, A. D., Froidevaux, L., von Clarmann, T., Kyrölä, E., Russell III, J. M., and Zawodny, J. M.: Groundbased microwave ozone radiometer measurements compared with Aura-MLS v2.2 and other instruments at two network for detection of atmospheric composition change sites, J. Geophys. Res., 112, D24S33, doi:10.1029/2007JD008720, 2007.

Brewer, A. W. and Milford, J. R.: The Oxford-Kew ozone sonde, Proc. R. Soc. Lon.-Ser. A, 256, 470-495, 1960.

Brönnimann, S., Bhend, J., Franke, J., Flückiger, S., Fischer, A. M., Bleisch, R., Bodeker, G., Hassler, B., Rozanov, E., and Schraner, M.: A global historical ozone data set and prominent features of stratospheric variability prior to 1979, Atmos. Chem. Phys., 13, 9623-9639, doi:10.5194/acp-13-9623-2013, 2013.

Brühl, C., Drayson, S. R., Russel III, J. M., Crutzen, P. J., McInerney, J. M., Purcell, P. N., Claude, H., Gernandt, H., McGee, T. J., McDermid, I. S., and Gunson, M. R.: Halogen Occultation Experiment ozone channel validation, J. Geophys. Res., 101, 10217-10240, 1996.

Burrows, J. P., Hölzle, E., Goede, A. P. H., Visser, H., and Fricke, W.: SCIAMACHY - Scanning Imaging Absorption Spectrometer for Atmospheric Chartography, Acta Astronaut., 35, 445-451, 1995.

Calisesi, Y.: Monitoring of stratospheric and mesospheric ozone with a ground-based microwave radiometer: data retrieval, analysis, and applications, $\mathrm{PhD}$ thesis, University of Bern, Institute of Applied Physics, Bern, Switzerland, available at: http://www.iap. unibe.ch/publications/pub-detail.php?lang=en\&id=149 (last access: 9 May 2014), 2000.

Carlotti, M., Brizzi, G., Papandrea, E., Prevedelli, M., Ridolfi, M., Dinelli, B. M., and Magnani, L.: GMTR: two-dimensional multitarget retrieval model for MIPAS-ENVISAT observations, Appl. Optics, 45, 716-727, 2006.

Casadio, S., Castelli, E., Dinelli, B. M., De Laurentis, M., Papandrea, E., Burini, A., and Carlotti, M.: MIPAS2D, MLS and ACEFTS inter-comparison of stratospheric profiles, in: ESA Living Planet Symposium, Edinburgh, Scottland, 9-13 September 2013, 2-P-300, 2013. 
Cionni, I., Eyring, V., Lamarque, J. F., Randel, W. J., Stevenson, D. S., Wu, F., Bodeker, G. E., Shepherd, T. G., Shindell, D. T., and Waugh, D. W.: Ozone database in support of CMIP5 simulations: results and corresponding radiative forcing, Atmos. Chem. Phys., 11, 11267-11292, doi:10.5194/acp11-11267-2011, 2011.

Connor, B. J., Parrish, A., Tsou, J. J., and McCormick, M. P.: Error analysis for the ground-based microwave ozone measurements during STOIC, J. Geophys. Res., 100, 9283-9291, 1995.

Cortesi, U., Lambert, J. C., De Clercq, C., Bianchini, G., Blumenstock, T., Bracher, A., Castelli, E., Catoire, V., Chance, K. V., De Mazière, M., Demoulin, P., Godin-Beekmann, S., Jones, N., Jucks, K., Keim, C., Kerzenmacher, T., Kuellmann, H., Kuttippurath, J., Iarlori, M., Liu, G. Y., Liu, Y., McDermid, I. S., Meijer, Y. J., Mencaraglia, F., Mikuteit, S., Oelhaf, H., Piccolo, C., Pirre, M., Raspollini, P., Ravegnani, F., Reburn, W. J., Redaelli, G., Remedios, J. J., Sembhi, H., Smale, D., Steck, T., Taddei, A., Varotsos, C., Vigouroux, C., Waterfall, A., Wetzel, G., and Wood, S.: Geophysical validation of MIPASENVISAT operational ozone data, Atmos. Chem. Phys., 7, 48074867, doi:10.5194/acp-7-4807-2007, 2007.

Cunnold, D. M., Wang, H., Chu, W. P., and Froidevaux, L.: Comparison between Stratospheric Aerosol and Gas Experiment II and microwave limb sounder ozone measurements and aliasing of SAGE II ozone trends in the lower stratosphere, J. Geophys. Res., 101, 10061-10075, 1996.

Cunnold, D. M., Wang, H. J., Thomason, L. W., Zawodny, J. M., Logan, J. A., and Megretskaia, I. A.: SAGE (version 5.96) ozone trends in the lower stratosphere, J. Geophys. Res., 105, 44454457, 2000.

Damadeo, R. P., Zawodny, J. M., Thomason, L. W., and Iyer, N.: SAGE version 7.0 algorithm: application to SAGE II, Atmos. Meas. Tech., 6, 3539-3561, doi:10.5194/amt-6-3539-2013, 2013

De Backer, H., De Muer, D., and De Sadelaer, G.: Comparison of ozone profiles obtained with Brewer-Mast and Z-ECC sensors during simultaneous ascents, J. Geophys. Res., 103, 1964119648, 1998.

Degenstein, D. A., Bourassa, A. E., Roth, C. Z., and Llewellyn, E. J.: Limb scatter ozone retrieval from 10 to $60 \mathrm{~km}$ using a multiplicative algebraic reconstruction technique, Atmos. Chem. Phys., 9, 6521-6529, doi:10.5194/acp-9-65212009, 2009.

DeLand, M. T., Taylor, S. L., Huang, L. K., and Fisher, B. L.: Calibration of the SBUV version 8.6 ozone data product, Atmos. Meas. Tech., 5, 2951-2967, doi:10.5194/amt-5-2951-2012, 2012

Deshler, T., Mercer, J., Smit, H. G. J., Stubi, R., Levrat, G., Johnson, B. J., Oltmans, S. J., Kivi, R., Davies, J., Thompson, A. M., Witte, J., Schmidlin, F. J., Brothers, G., and Sasaki, T.: Atmospheric comparison of electrochemical cell ozonesondes from different manufacturers, and with different cathode solution strengths: the Balloon Experiment on Standards for Ozonesondes, J. Geophys. Res., 113, D04307, doi:10.1029/2007JD008975, 2008.

Dinelli, B. M., Arnone, E., Brizzi, G., Carlotti, M., Castelli, E., Magnani, L., Papandrea, E., Prevedelli, M., and Ridolfi, M.: The MIPAS2D database of MIPAS/ENVISAT measurements retrieved with a multi-target 2-dimensional tomographic approach,
Atmos. Meas. Tech., 3, 355-374, doi:10.5194/amt-3-355-2010, 2010.

Dinelli, B. M., Arnone, E., and Castelli, E.: MIPAS2D - 10 years of MIPAS/Envisat measurements analyzed with a 2-D tomographic approach, in: ESA publications SP-708 Advances in Atmospheric Science and Applications, Noordwijk, ESA Communications, ISBN 978-92-9092-272-8, 2012.

Doicu, A., Schreier, F., Hilgers, S., von Bargen, A., Slijkhuis, S., Hess, M., and Aberle, B.: An efficient inversion algorithm for atmospheric remote sensing with application to UV limb observations, J. Quant. Spectrosc. Ra., 103, 193-208, doi:10.1016/j.jqsrt.2006.05.007, 2007.

Dufour, G., Eremenko, M., Griesfeller, A., Barret, B., LeFlochmoën, E., Clerbaux, C., Hadji-Lazaro, J., Coheur, P.-F., and Hurtmans, D.: Validation of three different scientific ozone products retrieved from IASI spectra using ozonesondes, Atmos. Meas. Tech., 5, 611-630, doi:10.5194/amt-5-611-2012, 2012.

Dupuy, E., Walker, K. A., Kar, J., Boone, C. D., McElroy, C. T., Bernath, P. F., Drummond, J. R., Skelton, R., McLeod, S. D., Hughes, R. C., Nowlan, C. R., Dufour, D. G., Zou, J., Nichitiu, F., Strong, K., Baron, P., Bevilacqua, R. M., Blumenstock, T., Bodeker, G. E., Borsdorff, T., Bourassa, A. E., Bovensmann, H., Boyd, I. S., Bracher, A., Brogniez, C., Burrows, J. P., Catoire, V., Ceccherini, S., Chabrillat, S., Christensen, T., Coffey, M. T., Cortesi, U., Davies, J., De Clercq, C., Degenstein, D. A., De Mazi Dupuy, E., Walker, K. A., Kar, J., Boone, C. D., McElroy, C. T., Bernath, P. F., Drummond, J. R., Skelton, R., McLeod, S. D., Hughes, R. C., Nowlan, C. R., Dufour, D. G., Zou, J., Nichitiu, F., Strong, K., Baron, P., Bevilacqua, R. M., Blumenstock, T., Bodeker, G. E., Borsdorff, T., Bourassa, A. E., Bovensmann, H., Boyd, I. S., Bracher, A., Brogniez, C., Burrows, J. P., Catoire, V., Ceccherini, S., Chabrillat, S., Christensen, T., Coffey, M. T., Cortesi, U., Davies, J., De Clercq, C., Degenstein, D. A., De Maziere, M., Demoulin, P., Dodion, J., Firanski, B., Fischer, H., Forbes, G., Froidevaux, L., Fussen, D., Gerard, P., Godin-Beekmann, S., Goutail, F., Granville, J., Griffith, D., Haley, C. S., Hannigan, J. W., Höpfner, M., Jin, J. J., Jones, A., Jones, N. B., Jucks, K., Kagawa, A., Kasai, Y., Kerzenmacher, T. E., Kleinböhl, A., Klekociuk, A. R., Kramer, I., Küllmann, H., Kuttippurath, J., Kyrölä, E., Lambert, J.-C., Livesey, N. J., Llewellyn, E. J., Lloyd, N. D., Mahieu, E., Manney, G. L., Marshall, B. T., McConnell, J. C., McCormick, M. P., McDermid, I. S., McHugh, M., McLinden, C. A., Mellqvist, J., Mizutani, K., Murayama, Y., Murtagh, D. P., Oelhaf, H., Parrish, A., Petelina, S. V., Piccolo, C., Pommereau, J.-P., Randall, C. E., Robert, C., Roth, C., Schneider, M., Senten, C., Steck, T., Strandberg, A., Strawbridge, K. B., Sussmann, R., Swart, D. P. J., Tarasick, D. W., Taylor, J. R., Tétard, C., Thomason, L. W., Thompson, A. M., Tully, M. B., Urban, J., Vanhellemont, F., Vigouroux, C., von Clarmann, T., von der Gathen, P., von Savigny, C., Waters, J. W., Witte, J. C., Wolff, M., and Zawodny, J. M.: Validation of ozone measurements from the Atmospheric Chemistry Experiment (ACE), Atmos. Chem. Phys., 9, 287-343, doi:10.5194/acp-9-287-2009, 2009.

Eckert, E., von Clarmann, T., Kiefer, M., Stiller, G. P., Lossow, S., Glatthor, N., Degenstein, D. A., Froidevaux, L., GodinBeekmann, S., Leblanc, T., McDermid, S., Pastel, M., Steinbrecht, W., Swart, D. P. J., Walker, K. A., and Bernath, P. F.: Drift-corrected trends and periodic variations in MIPAS 
IMK/IAA ozone measurements, Atmos. Chem. Phys., 14, 25712589, doi:10.5194/acp-14-2571-2014, 2014.

Fischer, H., Birk, M., Blom, C., Carli, B., Carlotti, M., von Clarmann, T., Delbouille, L., Dudhia, A., Ehhalt, D., Endemann, M., Flaud, J. M., Gessner, R., Kleinert, A., Koopman, R., Langen, J., López-Puertas, M., Mosner, P., Nett, H., Oelhaf, H., Perron, G., Remedios, J., Ridolfi, M., Stiller, G., and Zander, R.: MIPAS: an instrument for atmospheric and climate research, Atmos. Chem. Phys., 8, 2151-2188, doi:10.5194/acp-8-2151-2008, 2008.

Froidevaux, L., Read, W. G., Lungu, T. A., Cofield, R. E., Fishbein, E. F., Flower, D. A., Jarnot, R. F., Ridenoure, B. P., Shippony, Z., Waters, J. W., Margitan, J. J., McDermid, I. S., Stachnik, R. A., Peckham, G. E., Braathen, G., Deshler, T., Fishman, J., Hofmann, D. J., and Oltmans, S. J.: Validation of UARS Microwave Limb Sounder ozone measurements, J. Geophys. Res., 101, 10017-10060, 1996.

Froidevaux, L., Jiang, Y. B., Lambert, A., Livesey, N. J., Read, W. G., Waters, J. W., Browell, E. V., Hair, J. W., Avery, M. A., McGee, T. J., Twigg, L. W., Sumnicht, G. K., Jucks, K. W., Margitan, J. J., Sen, B., Stachnik, R. A., Toon, G. C., Bernath, P. F., Boone, C. D., Walker, K. A., Filipiak, M. J., Harwood, R. S., Fuller, R. A., Manney, G. L., Schwartz, M. J., Daffer, W. H., Drouin, B. J., Cofield, R. E., Cuddy, D. T., Jarnot, R. F., Knosp, B. W., Perun, V. S., Snyder, W. V., Stek, P. C., Thurstans, R. P., and Wagner, P. A.: Validation of Aura Microwave Limb Sounder stratospheric ozone measurements, J. Geophys. Res., 113, D15S20, doi:10.1029/2007JD008771, 2008.

García, O. E., Schneider, M., Redondas, A., González, Y., Hase, F., Blumenstock, T., and Sepúlveda, E.: Investigating the longterm evolution of subtropical ozone profiles applying groundbased FTIR spectrometry, Atmos. Meas. Tech., 5, 2917-2931, doi:10.5194/amt-5-2917-2012, 2012.

Gazeaux, J., Clerbaux, C., George, M., Hadji-Lazaro, J., Kuttippurath, J., Coheur, P.-F., Hurtmans, D., Deshler, T., Kovilakam, M., Campbell, P., Guidard, V., Rabier, F., and Thépaut, J.-N.: Intercomparison of polar ozone profiles by IASI/MetOp sounder with 2010 Concordiasi ozonesonde observations, Atmos. Meas. Tech., 6, 613-620, doi:10.5194/amt-6-613-2013, 2013.

Gebhardt, C., Rozanov, A., Hommel, R., Weber, M., Bovensmann, H., Burrows, J. P., Degenstein, D., Froidevaux, L., and Thompson, A. M.: Stratospheric ozone trends and variability as seen by SCIAMACHY during the last decade, Atmos. Chem. Phys., 14, 831-846, doi:10.5194/acp-14-831-2014, 2014.

Gille, J. and Russell III, J.: The limb infrared monitor of the stratosphere (LIMS): experiment description, performance and results, J. Geophys. Res., 89, 1525-1540, 1984.

Godin, S., Mégie, G., and Pelon, J.: Systematic lidar measurements of the stratospheric ozone vertical distribution, Geophys. Res. Lett., 16, 547-550, 1989.

Godin-Beekmann, S., Porteneuve, J., and Garnier, A.: Systematic DIAL ozone measurements at Observatoire de HauteProvence, J. Environ. Monitor., 5, 57-67, 2003.

Harris, N. R. P., et al.: Past changes in the Vertical Distribution of Ozone, Part III: Analysis and Interpretation of Trends, $\mathrm{SI}^{2} \mathrm{~N}$ special issue, in preparation, 2014.

Hase, F.: Inversion von Spurengasprofilen aus hochaufgelösten bodengebundenen FTIR-Messungen in Absorption, Wissenschaftliche Berichte Forschungszentrum Karlsruhe, FZKA
6512, Karlsruhe, Forschungszentrum Karlsruhe GmbH, ISSN 0947-8620, 2000.

Hase, F., Blumenstock, T., and Paton-Walsh, C.: Analysis of the instrumental line shape of high-resolution Fourier transform IR spectrometers with gas cell measurements and new retrieval software, Appl. Optics, 38, 3417-3422, 1999.

Hassler, B., Bodeker, G. E., Cionni, I., and Dameris, M.: A vertically resolved, monthly mean, ozone database from 1979 to 2100 for constraining global climate model simulations, Int. J. Remote Sens., 30, 4009-4018, 2009.

Hassler, B., Daniel, J. S., Johnson, B. J., Solomon, S., and Oltmans, S. J.: An assessment of changing ozone loss rates at South Pole: twenty-five years of ozonesonde measurements, J. Geophys. Res, 116, D22301, doi:10.1029/2011JD016353, 2011.

Hocke, K., Kämpfer, N., Ruffieux, D., Froidevaux, L., Parrish, A., Boyd, I., von Clarmann, T., Steck, T., Timofeyev, Y. M., Polyakov, A. V., and Kyrölä, E.: Comparison and synergy of stratospheric ozone measurements by satellite limb sounders and the ground-based microwave radiometer SOMORA, Atmos. Chem. Phys., 7, 4117-4131, doi:10.5194/acp-7-4117-2007, 2007.

Hurtmans, D., Coheur, P.-F., Wespes, C., Clarisse, L., Scharf, O., Clerbaux, C., Hadji-Lazaro, J., George, M., and Turquety, S.: FORLI radiative transfer and retrieval code for IASI, J. Quant. Spectrosc. Ra., 113, 1391-1408, 2012.

Imai, K., Manago, N., Mitsuda, C., Naito, Y., Nishimoto, E., Sakazki, T., Fujiwara, M., Froidevaux, L., von Clarmann, T., Stiller, G., Murtagh, D., Rong, P.-P., Mlynczak, M., Walker, K. A., Kinnison, D., Akiyoshi, H., Nakamura, T., Miyasaka, T., Nishibori, T., Mizobuchi, S., Kikuchi, K., Ozeki, H., Takahashi, C., Hayashi, H., Sano, T., Suzuki, M., Takayanagi, M., and Shiotani, M.: Validation of ozone data from the Superconducting Submillimeter-Wave Limb-Emission Sounder (SMILES), J. Geophys. Res., 118, 5750-5769, doi:10.1002/jgrd.50434, 2013.

Intergovernmental Panel on Climate Change/Technology and Economic Assessment Panel (IPCC/TEAP): Safeguarding the Ozone Layer and the Global Climate System: Issues Related to Hydrofluorocarbons and Perfluorocarbons, Cambridge University Press, UK, 478 pp., 2005.

Jégou, F., Urban, J., de La Noë, J., Ricaud, P., Le Flochmoën, E., Murtagh, D. P., Eriksson, P., Jones, A., Petelina, S., Llewellyn, E. J., Lloyd, N. D., Haley, C., Lumpe, J., Randall, C., Bevilacqua, R. M., Catoire, V., Huret, N., Berthet, G., Renard, J. B., Strong, K., Davies, J., Mc Elroy, C. T., Goutail, F., and Pommereau, J. P.: Technical Note: Validation of Odin/SMR limb observations of ozone, comparisons with OSIRIS, POAM III, ground-based and balloon-borne instruments, Atmos. Chem. Phys., 8, 3385-3409, doi:10.5194/acp-8-3385-2008, 2008.

Johnson, B. J., Oltmans, S. J., Voemel, H., Smit, H. G. J., Deshler, T., and Kroeger, C.: ECC Ozonesonde pump efficiency measurements and tests on the sensitivity to ozone of buffered and unbuffered ECC sensor cathode solutions, J. Geophys. Res., 107, 4393, doi:10.1029/2001JD000557, 2002.

Joiner, J. and Vasilkov, A. P.: First results from the OMI rotational Raman scattering cloud pressure algorithm, IEEE T. Geosci. Remote, 44, 1272-1282, 2006. 
Jones, A., Murtagh, D., Urban, J., Eriksson, P., and Rösevall, J.: Inter-comparison of Odin/SMR ozone measurements with MIPAS and balloon sonde data, Can. J. Phys., 85, 1111-1123, 2007.

Jones, A., Urban, J., Murtagh, D. P., Eriksson, P., Brohede, S., Haley, C., Degenstein, D., Bourassa, A., von Savigny, C., Sonkaew, T., Rozanov, A., Bovensmann, H., and Burrows, J.: Evolution of stratospheric ozone and water vapour time series studied with satellite measurements, Atmos. Chem. Phys., 9, 6055-6075, doi:10.5194/acp-9-6055-2009, 2009.

Kar, J., McElroy, C. T., Drummond, J. R., Zhou, J., Nichitiu, F., Walker, K. A., Randall, C. E., Nowlan, C. R., Dufour, D. G., Boone, C. D., Bernath, P. F., Trepte, C. R., Thomason, L. W., and McLinden, C.: Initial comparison of ozone and $\mathrm{NO}_{2}$ profiles from ACE-MAESTRO with balloon and satellite data, J. Geophys. Res., 112, D16301, doi:10.1029/2006JD008242, 2007.

Kasai, Y., Sagawa, H., Kreyling, D., Dupuy, E., Baron, P., Mendrok, J., Suzuki, K., Sato, T. O., Nishibori, T., Mizobuchi, S., Kikuchi, K., Manabe, T., Ozeki, H., Sugita, T., Fujiwara, M., Irimajiri, Y., Walker, K. A., Bernath, P. F., Boone, C., Stiller, G., von Clarmann, T., Orphal, J., Urban, J., Murtagh, D., Llewellyn, E. J., Degenstein, D., Bourassa, A. E., Lloyd, N. D., Froidevaux, L., Birk, M., Wagner, G., Schreier, F., Xu, J., Vogt, P., Trautmann, T., and Yasui, M.: Validation of stratospheric and mesospheric ozone observed by SMILES from International Space Station, Atmos. Meas. Tech., 6, 2311-2338, doi:10.5194/amt-6-2311-2013, 2013.

Kerr, J. B., Fast, H., McElroy, C. T., Oltmans, S. J., Lathrop, J. A., Kyrö, E., Paukkunen, A., Claude, H., Köhler, U., Sreedharan, C. R., Takao, T., and Tsukagoshi, Y.: The 1991 WMO international ozonesonde intercomparison at Vanscoy, Canada, Atmos. Ocean, 32, 685-716, 1994.

Kikuchi, K., Nishibori, T., Ochiai, S., Ozeki, H., Irimajiri, Y., Kasai, Y., Koike, M., Manabe, T., Mizukoshi, K., Murayama, Y., Nagahama, T., Sano, T., Sato, R., Seta, M., Takahashi, C., Takayanagi, M., Masuko, H., Inatani, J., Suzuki, M., and Shiotani, M.: Overview and early results of the Superconducting Submillimeter-Wave Limb-Emission Sounder (SMILES), J. Geophys. Res., 115, D23306, doi:10.1029/2010JD014379, 2010.

Kobayashi, J. and Toyama, Y.: On various methods of measuring the vertical distribution of atmospheric ozone (III) - carbon iodine type chemical ozonesonde, Pap. Meteorol. Geophys., 17, 113126, 1996.

Komhyr, W. D.: Electrochemical concentration cells for gas analysis, Ann. Geophys., 25, 203-210, 1969,

http://www.ann-geophys.net/25/203/1969/.

Kramarova, N. A., Bhartia, P. K., Frith, S. M., McPeters, R. D., and Stolarski, R. S.: Interpreting SBUV smoothing errors: an example using the quasi-biennial oscillation, Atmos. Meas. Tech., 6, 2089-2099, doi:10.5194/amt-6-2089-2013, 2013a.

Kramarova, N. A., Frith, S. M., Bhartia, P. K., McPeters, R. D., Taylor, S. L., Fisher, B. L., Labow, G. J., and DeLand, M. T.: Validation of ozone monthly zonal mean profiles obtained from the version 8.6 Solar Backscatter Ultraviolet algorithm, Atmos. Chem. Phys., 13, 6887-6905, doi:10.5194/acp-13-6887-2013, 2013b.

Kreyling, D., Sagawa, H., Wohltmann, I., Lehmann, R., and Kasai, Y.: SMILES zonal and diurnal variation climatology of strato- and mesospheric trace gases: $\mathrm{O}_{3}, \mathrm{HCl}, \mathrm{HNO}_{3}, \mathrm{ClO}, \mathrm{BrO}$, $\mathrm{HOCl}, \mathrm{HO}_{2}$, and temperature, J. Geophys. Res., 118, 1-16, doi:10.1002/2012JD019420, 2013.
Kroon, M., de Haan, J. F., Veefkind, J. P., Froidevaux, L., Wang, R., Kivi, R., and Hakkarainen, J. J.: Validation of operational ozone profiles from the ozone monitoring instrument, J. Geophys. Res., 116, D18305, doi:10.1029/2010JD015100, 2011.

Kuttippurath, J., Lefèvre, F., Pommereau, J.-P., Roscoe, H. K., Goutail, F., Pazmiño, A., and Shanklin, J. D.: Antarctic ozone loss in 1979-2010: first sign of ozone recovery, Atmos. Chem. Phys., 13, 1625-1635, doi:10.5194/acp-13-1625-2013, 2013.

Kyrölä, E., Tamminen, J., Sofieva, V., Bertaux, J. L., Hauchecorne, A., Dalaudier, F., Fussen, D., Vanhellemont, F., Fanton d'Andon, O., Barrot, G., Guirlet, M., Mangin, A., Blanot, L., Fehr, T., Saavedra de Miguel, L., and Fraisse, R.: Retrieval of atmospheric parameters from GOMOS data, Atmos. Chem. Phys., 10, 11881-11903, doi:10.5194/acp-10-118812010, 2010.

Kyrölä, E., Laine, M., Sofieva, V., Tamminen, J., Päivärinta, S.-M., Tukiainen, S., Zawodny, J., and Thomason, L.: Combined SAGE II-GOMOS ozone profile data set for 1984-2011 and trend analysis of the vertical distribution of ozone, Atmos. Chem. Phys., 13, 10645-10658, doi:10.5194/acp-13-10645-2013, 2013.

Laeng, A., Hubert, D., Verhoelst, T., von Clarmann, T., Dinelli, B. M., Dudhia, A., Raspollini, P., Stiller, G., Grabowski, U., Keppens, A., Kiefer, M., Sofieva, V., Froidevaux, L., Walker, K. A., Lambert, J.-C., and Zehner, C.: The ozone climate change initiative: comparison of four level 2 processors for the Michelson Interferometer for Passive Atmospheric Sounding (MIPAS), Remote Sens. Environ., under review, 2014.

Lambert, J.-C., et al.: Past changes in the Vertical Distribution of Ozone, Part II: Measurement Intercomparisons, $\mathrm{SI}^{2} \mathrm{~N}$ special issue, in preparation, 2014.

Levelt, P. F., Hilsenrath, E., Leppelmeier, G. W., Van Den Oord, G. H. J., Bhartia, P. K., Tamminen, J., de Haan, J. F., and Veefkind, J. P.: Science objectives of the ozone monitoring instrument, IEEE T. Geosci. Remote, 44, 1199-1208, doi:10.1109/TGRS.2006.872336, 2006a.

Levelt, P. F., van den Oord, G. H. J., Dobber, M. R., Malkki, A., Visser, H., de Vries, J., Stammes, P., Lundell, J. O., and Saari, H.: The ozone monitoring instrument, IEEE T. Geosci. Remote, 44, 1093-1101, 2006b.

Liu, G, Tarasick, D. W., Fioletov, V. E., Sioris, C. E., and Rochon, Y. J.: Ozone correlation lengths and measurement uncertainties from analysis of historical ozonesonde data in North America and Europe, J. Geophys. Res., 114, D04112, doi:10.1029/2008JD010576, 2009.

Liu, X., Bhartia, P. K., Chance, K., Spurr, R. J. D., and Kurosu, T. P.: Ozone profile retrievals from the Ozone Monitoring Instrument, Atmos. Chem. Phys., 10, 2521-2537, doi:10.5194/acp-10-25212010, 2010.

Livesey, N. J. and Read, W. G.: Direct retrieval of line-of-sight atmospheric structure from limb sounding observations, Geophys. Res. Lett., 27, 891-894, 2000.

Livesey, N. J., Read, W. G., Froidevaux, L., Waters, J. W., Pumphrey, H. C., Wu, D. L., Santee, M. L., Shippony, Z., and Jarnot, R. F.: The UARS Microwave Limb Sounder version 5 dataset: theory, characterization and validation, J. Geophys. Res., 108, 4378, doi:10.1029/2002JD002273, 2003. 
Livesey, N. J., Snyder, W. V., Read, W. G., and Wagner, P. A.: Retrieval algorithms for the EOS Microwave Limb Sounder (MLS) instrument, IEEE T. Geosci. Remote, 44, 1144-1155, 2006.

Llewellyn, E. J., Lloyd, N. D., Degenstein, D. A., Gattinger, R. L., Petelina, S. V., Bourassa, A. E., Wiensz, J. T., Ivanov, E. V., McDade, I. C., Solheim, B. H., McConnell, J. C., Haley, C. S., von Savigny, C., Sioris, C. E., McLinden, C. A., Griffioen, E., Kaminski, J., Evans, W. F. J., Puckrin, E., Strong, K., Wehrle, V., Hum, R. H., Kendall, D. J. W., Matsushita, J., Murtagh, D. P., Brohede, S., Stegman, J., Witt, G., Barnes, G., Payne, W. F., Piché, L., Smith, K., Warshaw, G., Deslauniers, D.-L., Marchand, P., Richardson, E. H., King, R. A., Wevers, I., McCreath, W., Kyrölä, E., Oikarinen, L., Leppelmeier, G. W., Auvinen, H., Mégie, G., Hauchecorne, A., Lefèvre, F., de La Nöe, J., Ricaud, P., Frisk, U., Sjoberg, F., von Schéele, F., and Nordh, L.: The OSIRIS instrument on the Odin Spacecraft, Can. J. Phys., 82, 411-422, 2004.

Lucke, R. L., Korwan, D. R., Bevilacqua, R. M., Hornstein, J. S., Shettle, E. P., Chen, D. T., Daehler, M., Lumpe, J. D., Fromm, M. D., Debrestian, D., Neff, B., Squire, M., KönigLanglo, G., and Davies, J.: The Polar Ozone and Aerosol Measurement (POAM) III instrument and early validation results, J. Geophys. Res., 104, 18785-18799, 1999.

Lumpe, J. D., Bevilacqua, R. M., Hoppel, K. W., and Randall, C. E.: POAM III retrieval algorithm and error analysis, J. Geophys. Res., 107, 4575, doi:10.1029/2002JD002137, 2002.

Mäder, J. A., Staehelin, J., Peter, T., Brunner, D., Rieder, H. E., and Stahel, W. A.: Evidence for the effectiveness of the Montreal Protocol to protect the ozone layer, Atmos. Chem. Phys., 10, 12161-12171, doi:10.5194/acp-10-12161-2010, 2010.

Maillard-Barras, E., Ruffieux, D., and Hocke, K.: Stratospheric ozone profiles over Switzerland measured by SOMORA, ozonesonde, and MLS/Aura satellite, Int. J. Remote Sens., 30, 4033-4041, 2009.

McDermid, I. S., Godin, S. M., and Lindquist, L. O.: Ground-based laser DIAL system for long-term measurements of stratospheric ozone, Appl. Optics, 29, 3603-3612, 1990.

McDermid, I. S., Bergwerff, J. B., Bodeker, G., Boyd, I. S., Brinksma, E. J., Connor, B. J., Farmer, R., Gross, M. R., Kimvilakani, P., Matthews, W. A., McGee, T. J., Ornel, F. T., Parrish, A., Singh, U., Swart, D. P. J., Tsou, J. J., Wang, P. H., and Zawodny, J.: OPAL: Network for the detection of stratospheric change ozone profiler assessment at Lauder, New Zealand. II. Intercomparison of revised results, J. Geophys. Res., 103, 2869328699, 1998a.

McDermid, I. S., Bergwerff, J. B., Bodeker, G., Boyd, I. S., Brinksma, E. J., Connor, B. J., Farmer, R., Gross, M. R., Kimvilakani, P., Matthews, W. A., McGee, T. J., Ormel, F. T., Parrish, A., Singh, U., Swart, D. P. J., Tsou, J. J., Wang, P. H., and Zawodny, J.: OPAL: Network for the detection of stratospheric change ozone profiler assessment at Lauder, New Zealand. I. Blind intercomparison, J. Geophys. Res., 103, 28683-28692, 1998b.

McElroy, C. T., Nowlan, C. R., Drummond, J. R., Bernath, P. F., Barton, D. V., Dufour, D. G., Midwinter, C., Hall, R. B., Ogyu, A., Ullberg, A., Wardle, D. I., Kar, J., Zou, J., Nichitiu, F., Boone, C. D., Walker, K. A., and Rowlands, N.: The ACEMAESTRO instrument on SCISAT: description, performance, and preliminary results, Appl. Optics, 46, 20, 4341-4356, 2007.
McGee, T. J., Gross, M., Ferrare, R., Heaps, W. S., and Singh, U. N.: Raman DIAL measurements of stratospheric ozone in the presence of volcanic aerosols, Geophys. Res. Lett., 20, 955-958, 1993.

McLandress, C., Jonsson, A. I., Plummer, D. A., Reader, M. C., Scinocca, J. F., and Shepherd, T. G.: Separating the dynamical effects of climate change and ozone depletion. Part I Southern Hemisphere stratosphere, J. Climate, 23, 5002-5020, doi:10.1175/2010JCLI3586.1, 2010.

McPeters, R. D. and Labow, G.: Climatology 2011: an MLS-derived ozone climatology for satellite retrieval algorithms, J. Geophys. Res., 117, D10303, doi:10.1029/2011JD017006, 2012.

McPeters, R. D., Miles, T., Flynn, L. E., Wellenmeyer, C. G., and Zawodny, J. M.: Comparison of SBUV and SAGE II profiles: implications for ozone trends, J. Geophys. Res., 99, 20513-20524, 1994.

McPeters, R. D., Hofmann, D. J., Clark, M., Froidevaux, L., Gross, M., Johnson, B., Koenig, G., McDermid, S., Murcray, F., Oltmans, S., Parrish, A., Singh, U., Tsou, J. J., and Zawodny, J.: Results from the 1995 stratospheric ozone profile intercomparison at Mauna Loa, J. Geophys. Res., 104, 30505-30514, 1999.

McPeters, R. D., Bhartia, P. K., Haffner, D., Labow, G. J., and Flynn, L.: The version 8.6 SBUV ozone data record: an overview, J. Geophys. Res., 118, 8032-8039, doi:10.1002/jgrd.50597, 2013.

Meijer, Y. J., Swart, D. P. J., Allaart, M., Andersen, S. B., Bodeker, G., Boyd, I., Braathena, G., Calisesia, Y., Claude, H., Dorokhov, V., von der Gathen, P., Gil, M., Godin-Beekmann, S., Goutail, F., Hansen, G., Karpetchko, A., Keckhut, P., Kelder, H. M., Koelemeijer, R., Kois, B., Koopman, R. M., Lambert, J.-C., Leblanc, T., McDermid, I. S., Pal, S., Kopp, G., Schets, H., Stubi, R., Suortti, T., Visconti, G., and Yela, M.: Pole-to-pole validation of ENVISAT/GOMOS ozone profiles using data from ground-based and balloon-sonde measurements, J. Geophys. Res., 109, D23305, doi:10.1029/2004JD004834, 2004.

Meijer, Y. J., Kelder, H. M., van der A, R. J., and van Oss, R. F.: Evaluation of Global Ozone Monitoring Experiment (GOME) ozone profiles from nine different algorithms, J. Geophys. Res., 111, D21306, doi:10.1029/2005JD006778, 2006.

Mieruch, S., Weber, M., von Savigny, C., Rozanov, A., Bovensmann, H., Burrows, J. P., Bernath, P. F., Boone, C. D., Froidevaux, L., Gordley, L. L., Mlynczak, M. G., Russell III, J. M., Thomason, L. W., Walker, K. A., and Zawodny, J. M.: Global and long-term comparison of SCIAMACHY limb ozone profiles with correlative satellite data (2002-2008), Atmos. Meas. Tech., 5, 771-788, doi:10.5194/amt-5-771-2012, 2012.

Mijling, B., Tuinder, O. N. E., van Oss, R. F., and van der A, R. J.: Improving ozone profile retrieval from spaceborne UV backscatter spectrometers using convergence behaviour diagnostics, Atmos. Meas. Tech., 3, 1555-1568, doi:10.5194/amt-3-1555-2010, 2010.

Mitsuda, C., Suzuki, M., Iwata, Y., Manago, N., Naito, Y., Takahashi, C., Imai, K., Nishimoto, E., Hayashi, H., Shiotani, M., Sano, T., Takayanagi, M., and Taniguchi, H.: Current status of level 2 product of Superconducting Submillimeter-Wave Limb-Emission Sounder (SMILES), Proc. SPIE, 8176, 81760M, doi:10.1117/12.898135, 2011. 
Miyagawa, K., Sasaki, T., Nakane, H., Petropavlovskikh, I., and Evans, R. D.: Reevaluation of long-term Umkehr data and ozone profiles at Japanese stations, J. Geophys. Res., 114, D07108, doi:10.1029/2008JD010658, 2009.

Moore, D. P. and Remedios, J. J.: Seasonality of Peroxyacetyl nitrate (PAN) in the upper troposphere and lower stratosphere using the MIPAS-E instrument, Atmos. Chem. Phys., 10, 6117-6128, doi:10.5194/acp-10-6117-2010, 2010.

Munro, R., Siddans, R., Reburn, W. J., and Kerridge, B. J.: Direct measurement of tropospheric ozone distributions from space, Nature, 392, 168-171, doi:10.1038/32392, 1998.

Murtagh, D., Frisk, U., Merino, F., Ridal, M., Jonsson, A., Stegman, J., Witt, G., Eriksson, P., Jiménez, C., Megie, G., de la Nöe, J., Ricaud, P., Baron, P., Hauchcorne, A., Llewellyn, E. J., Degenstein, D. A., Gattinger, R. L., Lloyd, N. D., Evans, W. F. J., McDade, I. C., Haley, C. S., Sioris, C., von Savigny, C., Solheim, B. H., McConnell, J. C., Strong, K., Richardson, E. H., Leppelmeier, G. W., Kyrölä, E., Auvinen, H., and Oikarinen, L.: An overview of the Odin Atmospheric Mission, Can. J. Phys., 80, 309-319, 2002.

Nair, P. J., Godin-Beekmann, S., Pazmino, A., Hauchecorne, A., Ancellet, G., Petropavlovskikh, I., Flynn, L. E., and Froidevaux, L.: Coherence of long-term stratospheric ozone vertical distribution time series used for the study of ozone recovery at a northern mid-latitude station, Atmos. Chem. Phys., 11, 49574975, doi:10.5194/acp-11-4957-2011, 2011.

Nair, P. J., Godin-Beekmann, S., Kuttippurath, J., Ancellet, G., Goutail, F., Pazmiño, A., Froidevaux, L., Zawodny, J. M., Evans, R. D., Wang, H. J., Anderson, J., and Pastel, M.: Ozone trends derived from the total column and vertical profiles at a northern mid-latitude station, Atmos. Chem. Phys., 13, 1037310384, doi:10.5194/acp-13-10373-2013, 2013.

Nakajima, H.: Preface to special section on ILAS-II: The Improved Limb Atmospheric Spectrometer-II, J. Geophys. Res., 111, D20S90, doi:10.1029/2006JD007412, 2006.

Nardi, B., Gille, J. C., Barnett, J. J., Randall, C. E., Harvey, V. L., Waterfall, A., Reburn, W. J., Leblanc, T., McGee, T. J., Twigg, L. W., Thompson, A. M., Godin-Beekmann, S., Bernath, P. F., Bojkov, B. R., Boone, C. D., Cavanaugh, C., Coffey, M. T., Craft, J., Craig, C., Dean, V., Eden, T. D., Francis, G., Froidevaux, L., Halvorson, C., Hannigan, J. W., Hepplewhite, C. L., Kinnison, D. E., Khosravi, R., Krinsky, C., Lambert, A., Lee, H., Loh, J., Massie, S. T., McDermid, I. S., Packman, D., Torpy, B., Valverde-Canossa, J., Walker, K. A., Whiteman, D. N., Witte, J. C., and Young, G.: Validation of HIRDLS ozone measurements, J. Geophys. Res., 113, D16S36, doi:10.1029/2007JD008837, 2008.

Newman, P. A., Nash, E. R., Kawa, S. R., Montzka, S. A., and Schauffler, S. M.: When will the Antarctic ozone hole recover?, Geophys. Res. Lett., 33, L12814, doi:10.1029/2005GL025232, 2006.

Nowlan, C. R., McElroy, C. T., and Drummond, J. R.: Measurements of the $\mathrm{O}_{2} \mathrm{~A}$ - and $\mathrm{B}$-bands for determining temperature and pressure profiles from ACE-MAESTRO: forward model and retrieval algorithm, J. Quant. Spectrosc. Ra., 108, 371-388, 2007.

Ochiai, S., Kikuchi, K., Nishibori, T., Manabe, T., Ozeki, H., Mizobuchi, S., and Irimajiri, Y.: Receiver performance of the Superconducting Submillimeter-Wave Limb-Emission Sounder (SMILES) on the international space station, IEEE T. Geosci.
Remote, 51, 3791-3802, doi:10.1109/TGRS.2012.2227758, 2013.

Palm, M., Melsheimer, C., Noël, S., Heise, S., Notholt, J., Burrows, J., and Schrems, O.: Integrated water vapor above $\mathrm{Ny}$ Ålesund, Spitsbergen: a multi-sensor intercomparison, Atmos. Chem. Phys., 10, 1215-1226, doi:10.5194/acp-10-1215-2010, 2010.

Parrington, M., Palmer, P. I., Henze, D. K., Tarasick, D. W., Hyer, E. J., Owen, R. C., Helmig, D., Clerbaux, C., Bowman, K. W., Deeter, M. N., Barratt, E. M., Coheur, P.-F., Hurtmans, D., Jiang, Z., George, M., and Worden, J. R.: The influence of boreal biomass burning emissions on the distribution of tropospheric ozone over North America and the North Atlantic during 2010, Atmos. Chem. Phys., 12, 2077-2098, doi:10.5194/acp-122077-2012, 2012.

Parrish, A., Connor, B. J., Tsou, J. J., Mcdermid, I. S., and Chu, W. P.: Ground-based microwave monitoring of stratospheric ozone, J. Geophys. Res., 97, 2541-2546, 1992.

Parrish, A., Boyd, I. S., Nedoluha, G. E., Bhartia, P. K., Frith, S. M., Kramarova, N. A., Connor, B. J., Bodeker, G. E., Froidevaux, L., Shiotani, M., and Sakazaki, T.: Diurnal variations of stratospheric ozone measured by ground-based microwave remote sensing at the Mauna Loa NDACC site: measurement validation and GEOSCCM model comparison, Atmos. Chem. Phys. Discuss., 13, 31855-31890, doi:10.5194/acpd-13-31855-2013, 2013.

Pelon, J., Godin, S., and Megie, G.: Upper stratospheric (30-50 km) lidar observations of the ozone vertical distribution, J. Geophys. Res., 91, 8666-8671, 1986.

Petropavlovskikh, I., Bhartia, P. K., and DeLuisi, J.: New Umkehr ozone profile retrieval algorithm optimized for climatological studies, Geophys. Res. Lett., 32, L16808, doi:10.1029/2005GL023323, 2005.

Petropavlovskikh, I., Evans, R., McConville, G., Oltmans, S., Quincy, D., Lantz, K., Disterhoft, P., Stanek, M., and Flynn, L.: Sensitivity of Dobson and Brewer Umkehr ozone profile retrievals to ozone cross-sections and stray light effects, Atmos. Meas. Tech., 4, 1841-1853, doi:10.5194/amt-4-1841-2011, 2011.

Polvani, L. M., Waugh, D. W., Correa, G. J. P., and Son, S. W.: Stratospheric ozone depletion: the main driver of twentiethcentury atmospheric circulation changes in the Southern Hemisphere, J. Climate, 24, 795-812, doi:10.1175/2010JCLI3772.1, 2011.

Pommier, M., Clerbaux, C., Law, K. S., Ancellet, G., Bernath, P., Coheur, P.-F., Hadji-Lazaro, J., Hurtmans, D., Nédélec, P., Paris, J.-D., Ravetta, F., Ryerson, T. B., Schlager, H., and Weinheimer, A. J.: Analysis of IASI tropospheric $\mathrm{O}_{3}$ data over the Arctic during POLARCAT campaigns in 2008, Atmos. Chem. Phys., 12, 7371-7389, doi:10.5194/acp-12-7371-2012, 2012.

Pougatchev, N. S., Connor, B. J., and Rinsland, C. P.: Infrared measurements of the ozone vertical distribution above Kitt Peak, J. Geophys. Res., 100, 16689-16697, 1995.

Rahpoe, N., von Savigny, C., Weber, M., Rozanov, A. V., Bovensmann, H., and Burrows, J. P.: Error Budget Analysis of the Limb Ozone Profiles using the SCIATRAN Model, Atmos. Meas. Tech., 6, 2825-2837, doi:10.5194/amt-6-2825-2013, 2013.

Randall, C. E., Rusch, D. W., Bevilacqua, R. M., Hoppel, K. W., Lumpe, J. D., Shettle, E., Thompson, E., Deaver, L., Zawodny, J., 
Kyrö, E., Johnson, B., Kelder, H., Dorokhov, V. M., KönigLanglo, G., and Gil, M.: Validation of POAM III ozone: comparisons with ozonesonde and satellite data, J. Geophys. Res., 108, 4367, doi:10.1029/2002JD002944, 2003.

Randel, W. J. and Wu, F.: A stratospheric ozone profile data set for 1979-2005: variability, trends, and comparisons with column ozone data, J. Geophys. Res., 112, D06313, doi:10.1029/2006JD007339, 2007.

Randel, W. J., Wu, F., Russell III, J. M., and Waters, J.: Spacetime patterns of trends in stratospheric constituents derived from UARS measurements, J. Geophys. Res., 104, 3711-3727, 1999.

Raspollini, P., Belotti, C., Burgess, A., Carli, B., Carlotti, M., Ceccherini, S., Dinelli, B. M., Dudhia, A., Flaud, J.-M., Funke, B., Höpfner, M., López-Puertas, M., Payne, V., Piccolo, C., Remedios, J. J., Ridolfi, M., and Spang, R.: MIPAS level 2 operational analysis, Atmos. Chem. Phys., 6, 5605-5630, doi:10.5194/acp6-5605-2006, 2006.

Raspollini, P., Arnone, E., Barbara, F., Carli, B., Castelli, E., Ceccherini, S., Dinelli, B. M., Dudhia, A., Kiefer, M., Papandrea, E., and Ridolfi, M.: Comparison of the MIPAS products obtained by four different level 2 processors, Annals of Geophysics, 56, Fast Track-1, doi:10.4401/ag-6338, 2013a.

Raspollini, P., Carli, B., Carlotti, M., Ceccherini, S., Dehn, A., Dinelli, B. M., Dudhia, A., Flaud, J.-M., López-Puertas, M., Niro, F., Remedios, J. J., Ridolfi, M., Sembhi, H., Sgheri, L., and von Clarmann, T.: Ten years of MIPAS measurements with ESA Level 2 processor V6 - Part 1: Retrieval algorithm and diagnostics of the products, Atmos. Meas. Tech., 6, 2419-2439, doi:10.5194/amt-6-2419-2013, 2013b.

Reber, C. A., Trevathan, C. E., McNeal, R. J., and Luther, M. R.: The Upper Atmosphere Research Satellite (UARS) mission, J. Geophys. Res., 98, 10643-10647, 1993.

Remsberg, E., Gordley, L. L., Marshall, B. T., Thompson, R. E., Burton, J., Bhatt, P., Harvey, V. L., Lingenfelser, G., and Natarajan, M.: The Nimbus 7 LIMS version 6 radiance conditioning and temperature retrieval methods and results, J. Quant. Spectrosc. Ra., 86, 395-424, doi:10.1016/j.jqsrt.2003.12.007, 2004.

Remsberg, E., Lingenfelser, G., Natarajan, M., Gordley, L., Marshall, B. T., and Thompson, E.: On the quality of the Nimbus 7 LIMS version 6 ozone for studies of the middle atmosphere, J. Quant. Spectrosc. Ra., 105, 492-518, doi:10.1016/j.jqsrt.2006.12.005, 2007.

Remsberg, E., Natarajan, M., Fairlie, T. D., Pawson, S., Wargan, K., Coy, L., Lingenfelser, G., and Kim, G.: On the inclusion of limb infrared monitor of the stratosphere (LIMS) ozone in a data assimilation system, J. Geophys. Res., 118, 7982-8000, doi:10.1002/jgrd.50566, 2013.

Ridolfi, M., Carli, B., Carlotti, M., von Clarmann, T., Dinelli, B. M., Dudhia, A., Flaud, J. M., Höpfner, M., Morris, P. E., Raspollini, P., Stiller, G., and Wells, R. J.: Optimized forward model and retrieval scheme for MIPAS near-real-time data processing, Appl. Optics, 39, 1323-1340, 2000.

Rodgers, C. D.: Retrieval of atmospheric temperature and composition from remote measurements of thermal radiation, Rev. Geophys., 14, 609-624, doi:10.1029/RG014i004p00609, 1976.

Rodgers, C. D.: Inverse Methods for Atmospheric Sounding: Theory and Practice, Series on Atmospheric, Oceanic and Planetary Physics, Vol. 2, World Scientific Publishing Co., Singapore, 2000 .
Rong, P. P., Russell III, J. M., Mlynczak, M. G., Remsberg, E. E., Marshall, B. T., Gordley, L. L., and López-Puertas, M.: Validation of Thermosphere Ionosphere Mesosphere Energetics and Dynamics/Sounding of the Atmosphere using Broadband Emission Radiometry (TIMED/SABER) v1.07 ozone at $9.6 \mu \mathrm{m}$ in altitude range 15-70 km, J. Geophys. Res., 114, D04306, doi:10.1029/2008JD010073, 2009.

Rothman, L. S., Jacquemart, D., Barbe, A., Chris Benner, D., Birk, M., Brown, L. R., Carleer, M. R., Chackerian, C., Chance, K., Coudert, L. H., Dana, V., Devi, V. M., Flaud, J.-M., Gamache, R. R., Goldman, A., Hartmann, J.-M., Jucks, K. W., Maki, A. G., Mandin, J.-Y., Massie, S. T., Orphal, J., Perrin, A., Rinsland, C. P., Smith, M. A. H., Tennyson, J., Tolchenov, R. N., Toth, R. A., Vander Auwera, J., Varanasi, P., and Wagner, G.: The HITRAN 2004 molecular spectroscopic database, J. Quant. Spectrosc. Ra., 96, 139-204, doi:10.1016/j.jqsrt.2004.10.008, 2005.

Rothman, L. S., Gordon, I. E., Barbe, A., Chris Benner, D., Bernath, P. F., Birk, M., Boudon, V., Brown, L. R., Campargue, A., Champion, J.-P., Chance, K., Coudert, L. H., Dana, V., Devi, V. M., Fally, S., Flaud, J.-M., Gamache, R. R., Goldman, A., Jacquemart, D., Kleiner, I., Lacome, N., Lafferty, W. J., Mandin, J.-Y., Massie, S. T., Mikhailenko, S. N., Miller, C. E., Moazzen-Ahmadi, N., Naumenko, O. V., Nikitin, A. V., Orphal, J., Perevalov, V. I., Perrin, A., Predoi-Cross, A., Rinsland, C. P., Rotger, M., Šimečková, M., Smith, M. A. H., Sung, K., Tashkun, S. A., Tennyson, J., Toth, R. A., Vandaele, A. C., and Vander Auwera, J.: The HITRAN 2008 molecular spectroscopic database, J. Quant. Spectrosc. Ra., 110, 533572, doi:10.1016/j.jqsrt.2009.02.013, 2009.

Russell III, J. M., Gordley, L. L., Park, J. H., Drayson, S. R., Tuck, A. F., Harries, J. E., Cicerone, R. J., Crutzen, P. J., and Frederick, J. E.: The Halogen Occultation Experiment, J. Geophys. Res., 98, 10777-10797, 1993.

Russell III, J. M., Mlynczak, M. G., Gordley, L. L., Tansock Jr., J. J., and Esplin, R.: Overview of the SABER experiment and preliminary calibration results, Proc. SPIE Int. Soc. Opt. Eng., 3756, 277-288, 1999.

Sakazaki, T., Fujiwara, M., Mitsuda, C., Imai, K., Manago, N., Naito, Y., Nakamura, T., Akiyoshi, H., Kinnison, D., Sano, T., Suzuki, M., and Shiotani, M.: Diurnal ozone variations in the stratosphere revealed in observations from the Superconducting Submillimeter-Wave Limb-Emission Sounder (SMILES) on board the International Space Station (ISS), J. Geophys. Res.Atmos., 118, 2991-3006, doi:10.1002/jgrd.50220, 2013.

Sasano, Y.: Preface, J. Geophys. Res., 107, 8204, doi:10.1029/2002JD002155, 2002.

Scannell, C., Hurtmans, D., Boynard, A., Hadji-Lazaro, J., George, M., Delcloo, A., Tuinder, O., Coheur, P.-F., and Clerbaux, C.: Antarctic ozone hole as observed by IASI/MetOp for 2008-2010, Atmos. Meas. Tech., 5, 123-139, doi:10.5194/amt5-123-2012, 2012.

Schneider, M., Hase, F., Blumenstock, T., Redondas, A., and Cuevas, E.: Quality assessment of $\mathrm{O}_{3}$ profiles measured by a state-of-the-art ground-based FTIR observing system, Atmos. Chem. Phys., 8, 5579-5588, doi:10.5194/acp-8-5579-2008, 2008. 
Smit, H. G. J.: Ozonesondes, in: Encyclopedia of Atmospheric Sciences, edited by: Holton, J., Pyle, J., and Curry, J., Academic Press, London, 1469-1476, 2002.

Smit, H. G. J. and Kley, D.: JOSIE: The 1996 WMO International intercomparison of ozonesondes under quasi flight conditions in the environmental simulation chamber at Jülich, WMO Global Atmosphere Watch Report No. 130, WMO TD No. 926, World Meteorological Organization, Geneva, 1998.

Smit, H. G. J. and Straeter, W.: JOSIE-2000, Jülich Ozone Sonde Intercomparison Experiment 2000, The 2000 WMO international intercomparison of operating procedures for ECC-ozonesondes at the environmental simulation facility at Jülich, WMO Global Atmosphere Watch Report No. 158, WMO TD No. 1225, World Meteorological Organization, Geneva, 2004.

Smit, H. G. J., Sträter, W., Johnson, B., Oltmans, S., Davies, J., Tarasick, D. W., Hoegger, B., Stubi, R., Schmidlin, F., Northam, T., Thompson, A., Witte, J., Boyd, I., and Posny, F.: Assessment of the performance of ECC-ozonesondes under quasi-flight conditions in the environmental simulation chamber: insights from the Jülich Ozone Sonde Intercomparison Experiment (JOSIE), J. Geophys. Res., 112, D19306, doi:10.1029/2006JD007308, 2007.

Smit, H. G. J. and ASOPOS-panel: Quality Assurance and Quality Control for Ozonesonde Measurements in GAW, WMO Global Atmosphere Watch report series, No. 201, World Meteorological Organization, Geneva, available at: http://www.wmo.int/ pages/prog/arep/gaw/documents/GAW_201_30_Sept.pdf (last access:8 Novembe 2013), 2012.

Sofieva, V. F., Rahpoe, N., Tamminen, J., Kyrölä, E., Kalakoski, N., Weber, M., Rozanov, A., von Savigny, C., Laeng, A., von Clarmann, T., Stiller, G., Lossow, S., Degenstein, D., Bourassa, A., Adams, C., Roth, C., Lloyd, N., Bernath, P., Hargreaves, R. J., Urban, J., Murtagh, D., Hauchecorne, A., Dalaudier, F., van Roozendael, M., Kalb, N., and Zehner, C.: Harmonized dataset of ozone profiles from satellite limb and occultation measurements, Earth Syst. Sci. Data, 5, 349-363, doi:10.5194/essd-5-349-2013, 2013.

Sonkaew, T., Rozanov, V. V., von Savigny, C., Rozanov, A., Bovensmann, H., and Burrows, J. P.: Cloud sensitivity studies for stratospheric and lower mesospheric ozone profile retrievals from measurements of limb-scattered solar radiation, Atmos. Meas. Tech., 2, 653-678, doi:10.5194/amt-2-653-2009, 2009.

SPARC: SPARC-IOC-GAW Assessment of Trends in the Vertical Distribution of Ozone, SPARC Report No. 1, WMO Global Ozone Research and Monitoring Project Report No. 43, World Meteorological Organization, Geneva, 1998.

Steck, T., von Clarmann, T., Fischer, H., Funke, B., Glatthor, N., Grabowski, U., Höpfner, M., Kellmann, S., Kiefer, M., Linden, A., Milz, M., Stiller, G. P., Wang, D. Y., Allaart, M., Blumenstock, Th., von der Gathen, P., Hansen, G., Hase, F., Hochschild, G., Kopp, G., Kyrö, E., Oelhaf, H., Raffalski, U., Redondas Marrero, A., Remsberg, E., Russell III, J., Stebel, K., Steinbrecht, W., Wetzel, G., Yela, M., and Zhang, G.: Bias determination and precision validation of ozone profiles from MIPASEnvisat retrieved with the IMK-IAA processor, Atmos. Chem. Phys., 7, 3639-3662, doi:10.5194/acp-7-3639-2007, 2007.

Steinbrecht, W., Claude, H., Schönenborn, F., McDermid, I. S., Leblanc, T., Godin-Beekmann, S., Keckhut, P., Hauchecorne, A., van Gijsel, J. A. E., Swart, D. P. J., Bodeker, G. E., Parrish, A., Boyd, I. S., Kämpfer, N., Hocke, K., Stolarski, R. S.,
Frith, S. M., Thomason, L. W., Remsberg, E. E., von Savigny, C., Rozanov, A., and Burrows, J. P.: Ozone and temperature trends in the upper stratosphere at five stations of the Network for the Detection of Atmospheric Composition Change, Int. J. Remote Sens., 30, 3875-3886, doi:10.1080/01431160902821841, 2009.

Stiller, G. P., Kiefer, M., Eckert, E., von Clarmann, T., Kellmann, S., García-Comas, M., Funke, B., Leblanc, T., Fetzer, E., Froidevaux, L., Gomez, M., Hall, E., Hurst, D., Jordan, A., Kämpfer, N., Lambert, A., McDermid, I. S., McGee, T., Miloshevich, L., Nedoluha, G., Read, W., Schneider, M., Schwartz, M., Straub, C., Toon, G., Twigg, L. W., Walker, K., and Whiteman, D. N.: Validation of MIPAS IMK/IAA temperature, water vapor, and ozone profiles with MOHAVE-2009 campaign measurements, Atmos. Meas. Tech., 5, 289-320, doi:10.5194/amt-5289-2012, 2012.

Studer, S., Hocke, K., Pastel, M., Godin-Beekmann, S., and Kämpfer, N.: Intercomparison of stratospheric ozone profiles for the assessment of the upgraded GROMOS radiometer at Bern, Atmos. Meas. Tech. Discuss., 6, 6097-6146, doi:10.5194/amtd6-6097-2013, 2013.

Stübi, R., Levrat, G., Hoegger, B., Viatte, P., Staehelin, J., and Schmidlin, F. J.: In-flight comparison of Brewer-Mast and electrochemical concentration cell ozonesondes, J. Geophys. Res., 113, D13302, doi:10.1029/2007JD009091, 2008.

Sugita, T., Yokota, T., Nakajima, H., Kanzawa, H., Nakane, H., Gernandt, H., Yushkov, V., Shibasaki, K., Deshler, T., Kondo, Y., Godin, S., Goutail, F., Pommereau, J.-P., Camy-Peyret, C., Payan, S., Jeseck, P., Renard, J.-B., Bösch, H., Fitzenberger, R., Pfeilsticker, K., von König, M., Bremer, H., Küllmann, H., Schlager, H., Margitan, J. J., Stachnik, B., Toon, G. C., Jucks, K., Traub, W. A., Johnson, D. G., Murata, I., Fukunishi, H., and Sasano, Y.: Validation of ozone measurements from the Improved Limb Atmospheric Spectrometer, J. Geophys. Res., 107, 8212, doi:10.1029/2001JD000602, 2002.

Sugita, T., Nakajima, H., Yokota, T., Kanzawa, H., Gernandt, H., Herber, A., von der Gathen, P., König-Langlo, G., Sato, K., Dorokhov, V., Yushkov, V. A., Murayama, Y., Yamamori, M., Godin-Beekmann, S., Goutail, F., Roscoe, H. K., Deshler, T., Yela, M., Taalas, P., Kyrö, E., Oltmans, S. J., Johnson, B. J., Allaart, M., Litynska, Z., Klekociuk, A., Andersen, S. B., Braathen, G. O., De Backer, H., Randall, C. E., Bevilacqua, R. M., Taha, G., Thomason, L. W., Irie, H., Ejiri, M. K., Saitoh, N., Tanaka, T., Terao, Y., Kobayashi, H., and Sasano, Y.: Ozone profiles in the high-latitude stratosphere and lower mesosphere measured by the Improved Limb Atmospheric Spectrometer (ILAS)II: comparison with other satellite sensors and ozonesondes, J. Geophys. Res., 111, D11S02, doi:10.1029/2005JD006439, 2006.

Tamminen, J., Kyrölä, E., Sofieva, V. F., Laine, M., Bertaux, J.-L., Hauchecorne, A., Dalaudier, F., Fussen, D., Vanhellemont, F., Fanton-d'Andon, O., Barrot, G., Mangin, A., Guirlet, M., Blanot, L., Fehr, T., Saavedra de Miguel, L., and Fraisse, R.: GOMOS data characterisation and error estimation, Atmos. Chem. Phys., 10, 9505-9519, doi:10.5194/acp-10-9505-2010, 2010.

Tarasick, D. W. and Slater, R.: Ozone in the troposphere: measurements, climatology, budget, and trends, Atmos. Ocean, 46, 93115, doi:10.3137/ao.460105, 2008.

Tegtmeier, S., Hegglin, M. I., Anderson, J., Bourassa, A., Brohede, S., Degenstein, D., Froidevaux, L., Fuller, R., Funke, B., Gille, J., Jones, A., Kasai, Y., Krüger, K., Kyrölä, E., Lin- 
genfelser, G., Lumpe, J., Nardi, B., Neu, J., Pendlebury, D., Remsberg, E., Rozanov, A., Smith, L., Toohey, M., Urban, J., von Clarmann, T., Walker, K. A., and Wang, R. H. J.: SPARC Data Initiative: A comparison of ozone climatologies from international satellite limb sounders, J. Geophys. Res., 118, 1-19, doi:10.1002/2013JD019877, 2013.

Terao, Y. and Logan, J. A.: Consistency of time series and trends of stratospheric ozone as seen by ozonesonde, SAGE II, HALOE, and SBUV(/2), J. Geophys. Res., 112, D06310, doi:10.1029/2006JD007667, 2007.

Tikhonov, A. N.: On the solution of incorrectly stated problems and a method of regularization, Dokl. Acad. Nauk SSSR, Vol. 151, p. 501, 1963.

Toohey, M., Hegglin, M. I., Tegtmeier, S., Anderson, J., Anel, J. A., Bourassa, A., Brohede, S., Degenstein, D., Froidevaux, L., Fuller, R., Funke, B., Gille, J., Jones, A., Kasai, Y., Kruger, K., Kyrölä, E., Neu, J. L., Rozanov, A., Smith, L., Urban. J., von Clarmann, T., Walker, K. A., and Wang, R.: Characterizing sampling biases in the trace gas climatologies of the SPARC Data Initiative, J. Geophys. Res., 118, 11847-11862, doi:10.1002/jgrd.50874, 2013.

Tsou, J. J., Connor, B. J., Parrish, A., McDermid, I. S., Pierce, R. B., Boyd, I. S., Bodeker, G. E., Chu, W. P., Russell III, J. M., Swart, D. P. J., and McGee, T. J.: NDSC millimeter save observations at Lauder, New Zealand, 1992-1998, improved methodology, validation, and variation study, J. Geophys. Res., 105, 24263-24281, 2000.

Tukiainen, S., Kyrölä, E., Verronen, P. T., Fussen, D., Blanot, L., Barrot, G., Hauchecorne, A., and Lloyd, N.: Retrieval of ozone profiles from GOMOS limb scattered measurements, Atmos. Meas. Tech., 4, 659-667, doi:10.5194/amt-4-659-2011, 2011.

Urban, J., Lautié, N., Jimènez, C., Le Flochmoën, E., Dupuy, E., Eriksson, P., Frisk, U., Murtagh, D., de La Noë, J., Olberg, M., and Ricaud, P.: Odin/SMR limb observations of stratospheric trace gases: level-2 processing of $\mathrm{ClO}, \mathrm{N}_{2} \mathrm{O}, \mathrm{O}_{3}$, and $\mathrm{HNO}_{3}$, J. Geophys. Res., 110, D14307, doi:10.1029/2004JD005741, 2005.

Urban, J., Murtagh, D., Lautié, N., Barret, B., Dupuy, E., de La Noë, J., Eriksson, P., Frisk, U., Jones, A., Le Flochmoë, E., Olberg, M., Piccolo, C., Ricaud, P., and Rösevall, J.: Odin/SMR limb observations of trace gases in the Polar lower stratosphere during 2004-2005, in: Proc. ESA Atmospheric Science Conference, European Space Agency publications ESA-SP-628, Frascati, Italy, 8-12 May 2006, ISBN-92-9092-939-1, ISSN-1609042X, 2006.

van Gijsel, J. A. E., Swart, D. P. J., Baray, J.-L., Bencherif, H., Claude, H., Fehr, T., Godin-Beekmann, S., Hansen, G. H., Keckhut, P., Leblanc, T., McDermid, I. S., Meijer, Y. J., Nakane, H., Quel, E. J., Stebel, K., Steinbrecht, W., Strawbridge, K. B., Tatarov, B. I., and Wolfram, E. A.: GOMOS ozone profile validation using ground-based and balloon sonde measurements, Atmos. Chem. Phys., 10, 10473-10488, doi:10.5194/acp-1010473-2010, 2010.

Van Peet, J. C. A., van der A, R. J., de Laat, A. T. J., Tuinder, O. N. E., Koenig-Langlo, G., and Wittig, J.: Height resolved ozone hole structure as observed by the Global Ozone Monitoring Experiment-2, Geophys. Res. Lett., 36, L11816, doi:10.1029/2009GL038603, 2009.

Veefkind, J. P., Aben, I., McMullan, K., Förster, H., de Vries, J., Otter, G., Claas, J., Eskes, H. J., de Haan, J. F., Kleipool, Q., van Weele, M., Hasekamp, O., Hoogeveen, R., Landgraf, J., Snel, R., Tol, P., Ingmann, P., Voors, R., Kruizinga, B., Vink, R., Visser, H., Levelt, P. F.: TROPOMI on the ESA sentinel-5 precursor: a GMES mission for global observations of the atmospheric composition for climate, air quality and ozone layer applications, Remote Sens. Environ., 120, 70-83, doi:10.1016/j.rse.2011.09.027, 2012.

Vigouroux, C., De Mazi Vigouroux, C., De Maziere, M., Demoulin, P., Servais, C., Hase, F., Blumenstock, T., Kramer, I., Schneider, M., Mellqvist, J., Strandberg, A., Velazco, V., Notholt, J., Sussmann, R., Stremme, W., Rockmann, A., Gardiner, T., Coleman, M., and Woods, P.: Evaluation of tropospheric and stratospheric ozone trends over Western Europe from ground-based FTIR network observations, Atmos. Chem. Phys., 8, 6865-6886, doi:10.5194/acp-8-6865-2008, 2008.

Von Clarmann, T., Glatthor, N., Grabowski, U., Höpfner, M., Kellmann, S., Kiefer, M., Linden, A., Tsidu, G. M., Milz, M., Steck, T., Stiller, G. P., Wang, D. Y., and Fischer, H.: Retrieval of temperature and tangent altitude pointing from limb emission spectra recorded from space by the Michelson Interferometer for Passive Atmospheric Sounding (MIPAS), J. Geophys. Res., 108, 4736, doi:10.1029/2003JD003602, 2003.

von Clarmann, T., Höpfner, M., Kellmann, S., Linden, A., Chauhan, S., Funke, B., Grabowski, U., Glatthor, N., Kiefer, M., Schieferdecker, T., Stiller, G. P., and Versick, S.: Retrieval of temperature, $\mathrm{H}_{2} \mathrm{O}, \mathrm{O}_{3}, \mathrm{HNO}_{3}, \mathrm{CH}_{4}, \mathrm{~N}_{2} \mathrm{O}, \mathrm{ClONO}_{2}$ and $\mathrm{ClO}$ from MIPAS reduced resolution nominal mode limb emission measurements, Atmos. Meas. Tech., 2, 159-175, doi:10.5194/amt-2-159-2009, 2009.

von Clarmann, T., Stiller, G., Grabowski, U., Eckert, E., and Orphal, J.: Technical Note: Trend estimation from irregularly sampled, correlated data, Atmos. Chem. Phys., 10, 6737-6747, doi:10.5194/acp-10-6737-2010, 2010.

von Savigny, C., Kaiser, J. W., Bovensmann, H., Burrows, J. P., McDermid, I. S., and Leblanc, T.: Spatial and temporal characterization of SCIAMACHY limb pointing errors during the first three years of the mission, Atmos. Chem. Phys., 5, 2593-2602, doi:10.5194/acp-5-2593-2005, 2005.

Wang, H. J., Cunnold, D. M., and Bao, X.: A critical analysis of stratospheric aerosol and gas experiment ozone trends, J. Geophys. Res., 101, 12495-12514, 1996.

Wang, H. J., Cunnold, D. M., Thomason, L. W., Zawodny, J. M., and Bodeker, G. E.: Assessment of SAGE version 6.1 ozone data quality, J. Geophys. Res., 107, 4691, doi:10.1029/2002JD002418, 2002.

Waters, J. W.: Microwave limb sounding, in: Atmospheric Remote Sensing by Microwave Radiometry, edited by: Janssen, M. A., chap. 8, J. Wiley, New York, USA, 383-434, 1993.

Waters, J. W., Froidevaux, L., Harwood, R. S., Jarnot, R. F., Pickett, H. M., Read, W. G., Siegel, P. H., Cofield, R. E., Filipiak, M. J., Flower, D. A., Holden, J. R., Lau, G. K., Livesey, N. J., Manney, G. L., Pumphrey, H. C., Santee, M. L., Wu, D. L., Cuddy, D. T., Lay, R. R., Loo, M. S., Perun, V. S., Schwartz, M. J., Stek, P. C., Thurstans, R. P., Boyles, M. A., Chandra, S., Chavez, M. C., Chen, G.-S., Chudasama, B. V., Dodge, R., Fuller, R. A., Girard, M. A., Jiang, J. H., Jiang, Y., Knosp, B. W., LaBelle, R. C., Lam, J. C., Lee, K. A., Miller, D., Oswald, J. E., Patel, N. C., Pukala, D. M., Quintero, O., Scaff, D. M., Snyder, W. V., Tope, M. C., Wagner, P. A., and 
Walch, M. J.: The Earth Observing System Microwave Limb Sounder (EOS MLS) on the Aura satellite, IEEE T. Geosci. Remote, 44, 1075-1092, doi:10.1109/TGRS.2006.873771, 2006.

Waymark, C., Walker, K. A., Boone, C. D., and Bernath, P. F.: ACEFTS version 3.0 data set: validation and data processing update, Annals of Geophysics, 56, Fast Track-1, doi:10.4401/ag-6339, 2013.

WMO (World Meteorological Organization): Scientific Assessment of Ozone Depletion: 2006, Global Ozone Research and Monitoring Project - Report No. 50, Geneva, Switzerland, 2007.

WMO (World Meteorological Organization): Towards a Better Knowledge of Umkehr Measurements: A Detailed Study of Data from Thirteen Dobson Intercomparisons, GAW Report No. 180, Geneva, Switzerland, 2008.

WMO (World Meteorological Organization): Scientific Assessment of Ozone Depletion: 2010, Global Ozone Research and Monitoring Project - Report No. 52, Geneva, Switzerland, 2011.

Worden, H. M., Logan, J., Worden, J. R., Beer, R., Bowman, K., Clough, S. A., Eldering, A., Fisher, B., Gunson, M. R., Herman, R. L., Kulawik, S. S., Lampel, M. C., Luo, M., Megretskaia, I. A., Osterman, G. B., and Shephard, M. W.: Comparisons of Tropospheric Emission Spectrometer (TES) ozone profiles to ozonesodes: methods and initial results, J. Geophys. Res., 112, D03309, doi:10.1029/2006JD007258, 2007.
Yu, J. R. and She, C. Y.: Climatology of a midlatitude mesopause region observed by a lidar at Fort Collins, Colorado $\left(40.6^{\circ} \mathrm{N}\right.$, $\left.105^{\circ} \mathrm{W}\right)$, J. Geophys. Res., 100, 7441-7452, 1995.

Zanis, P., Maillard, E., Staehelin, J., Zerefos, C., Kosmidis, E., Tourpali, K., and Wohltmann, I.: On the turnaround of stratospheric ozone trends deduced from the reevaluated Umkehr record of Arosa, Switzerland, J. Geophys. Res., 111, D22307, doi:10.1029/2005JD006886, 2006.

Ziemke, J. R. and Chandra, S.: Development of a climate record of tropospheric and stratospheric column ozone from satellite remote sensing: evidence of an early recovery of global stratospheric ozone, Atmos. Chem. Phys., 12, 5737-5753, doi:10.5194/acp-12-5737-2012, 2012. 